\title{
دور القرائن القضائية فى الإثبات الإدارى
}

\author{
shel \\ د. دوزى أحمد إبراهيم حتحوت \\ أستاذ القانون العام المساعد بقسم الأنظمت إحتر \\ بكليت الشريعت والدراسات الإسلاميتت بالأحساء \\ جامعتّا الإمام محمد بن سعود الإسلاميتة
}




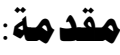

يتميز الإثبات فى الدعوى الإدارية بسمات خاصة تجعله مفترقا عن نظيره فى

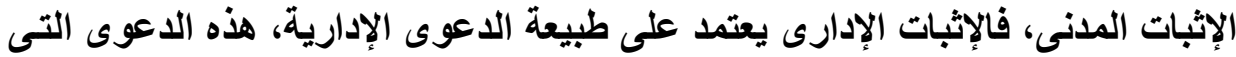

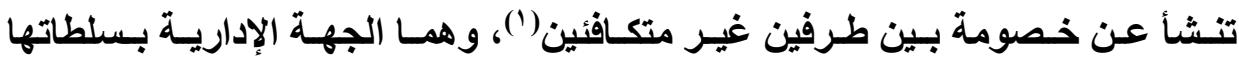

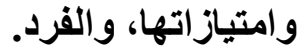

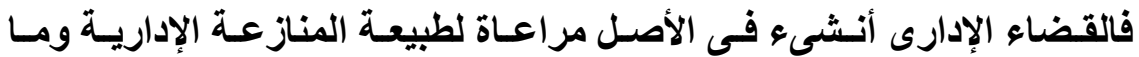

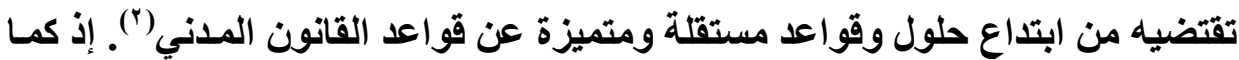

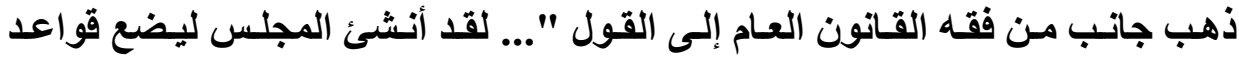

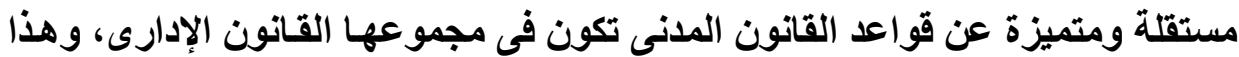

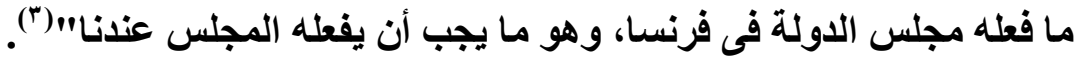

(1) مصطفى كمال وصفى، خصائص الإثبات أمام القضاء الإدارى، مقال منشور فى مجلة المحاماه،

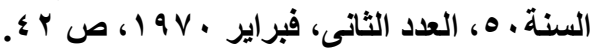

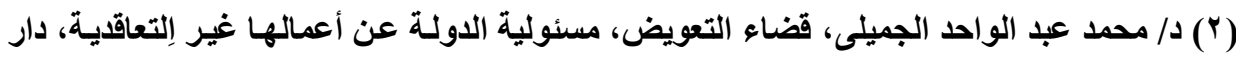

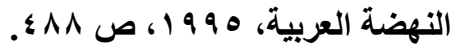

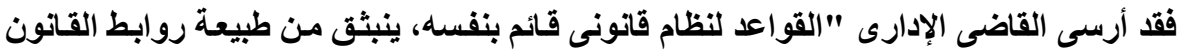

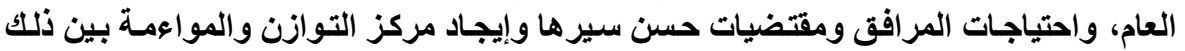

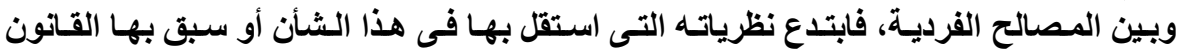

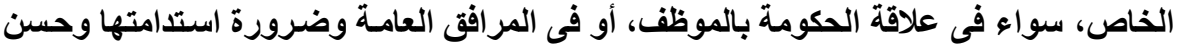

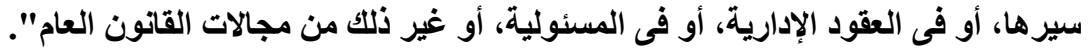

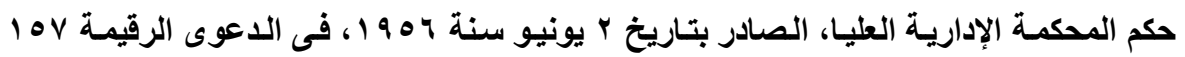

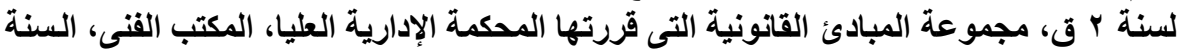

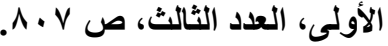

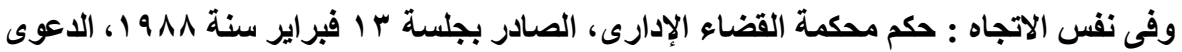

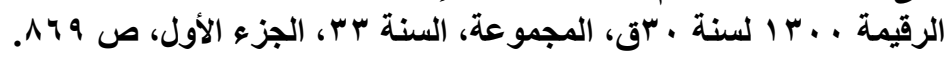

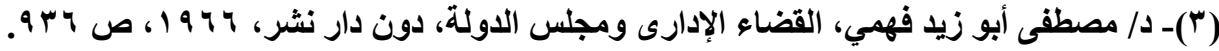


كان لاعتبار القاضى الإدارى المصدر الرئيس لقواعد وأحكام المنازعة الإداريـة

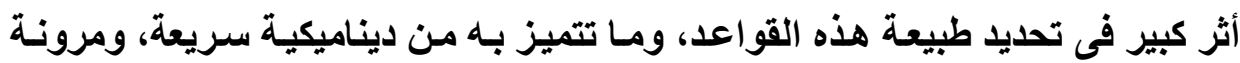

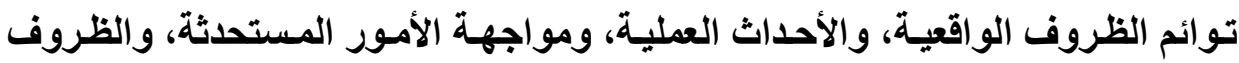

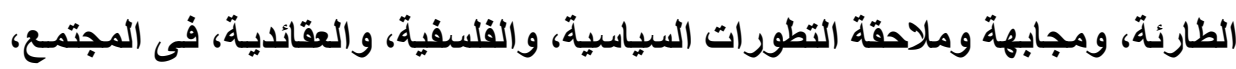

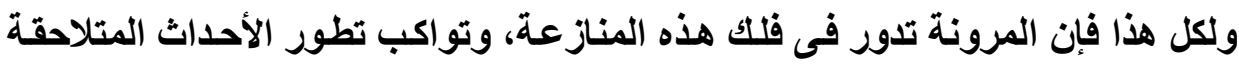
المتغيرة على المجتمع المطبقة فيه.

ولا شكك يمثل الإثبات دور كبير فى إبراز الحق وإسناده إلى أهله، ولذلك لم يتردد

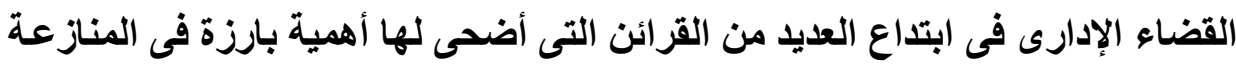

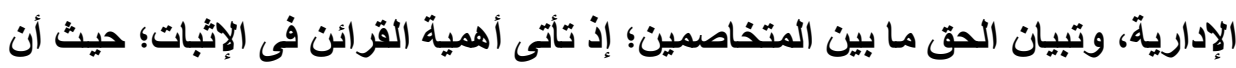

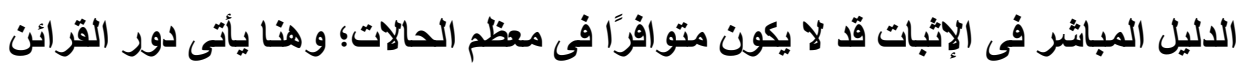

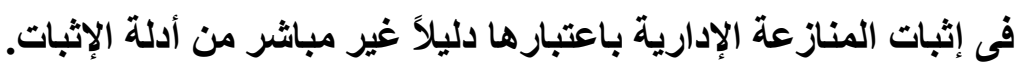
إذ أن الإثبات فيها لا ينصب مباثرة على الواقعة المراد إثباتها، بل على واقعة

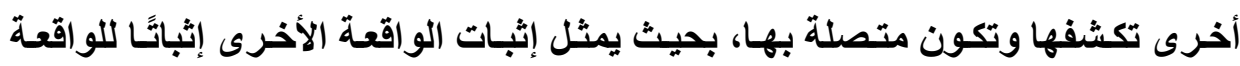

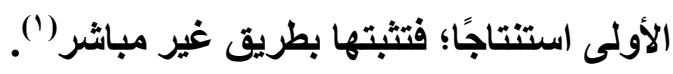
أهميدة الدراسة:

وإن كانت القرينة هو مـا يستخلصه المشرع أو القاضى من أمر معلوم للالالة

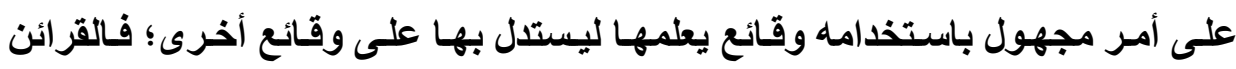

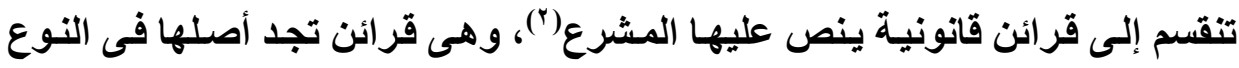

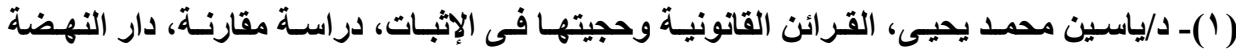

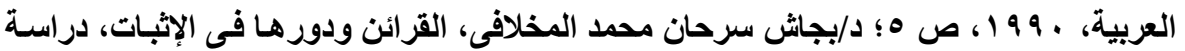

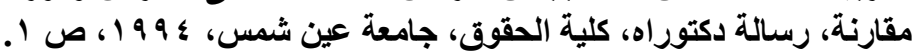

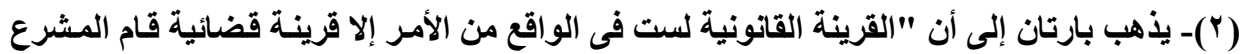

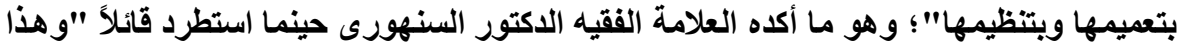
$=$ 
الآخر من القرائن، وهى القرائن القضائية التى يستنبطها القاضى من المنازعة الإدارية

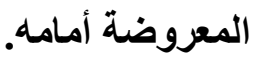

ومن هنا تبرز أهمية القرائن القضائية لما لها من دور فعال فى عملية الإثبات

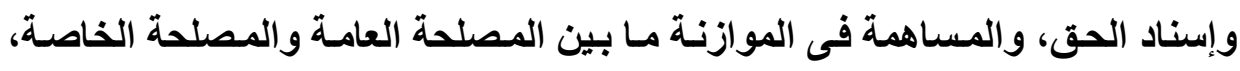

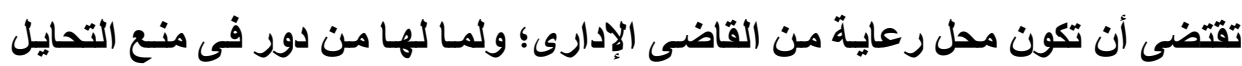

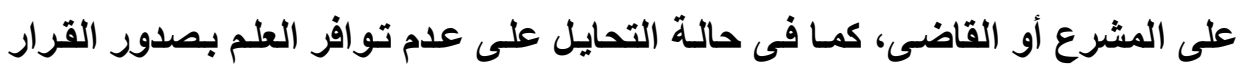

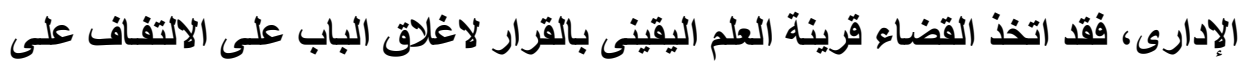

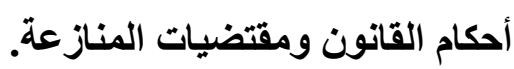

خاصة أن القاضى فى أثناء فصله فى المنازعة المعروضة عليه قد يتبين له من

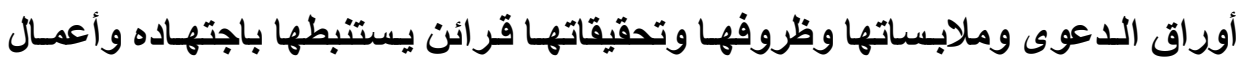

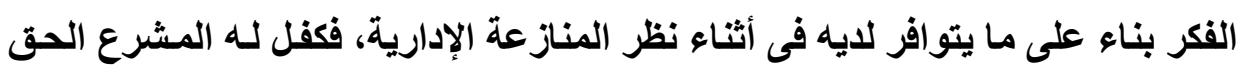

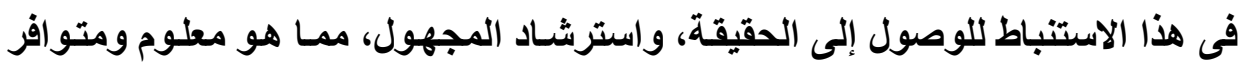

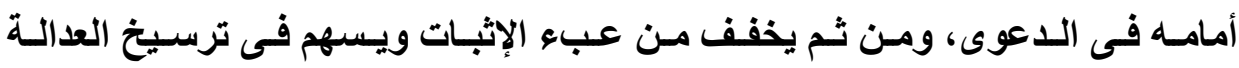

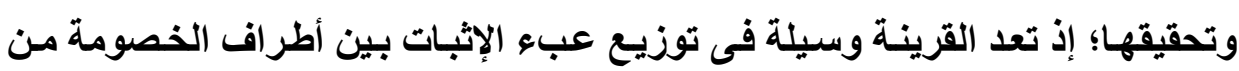

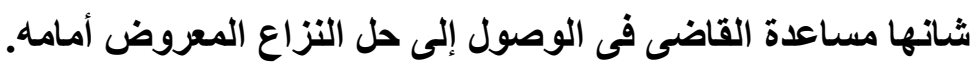

هنهة الدراسة:

وقد اعتمد الباحث على المنهج المقارن التطبيقى فى بحثه لما لـه من أهبة، إذ إذ إنها

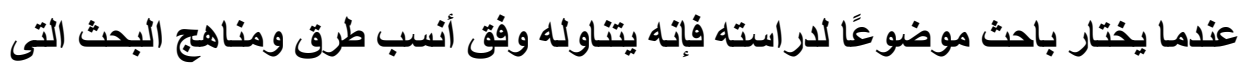

صحيح من حيث التكييف والتأصيل، فالقرينة القانونية ليست فى الأصل إلا قرينة قضائية تواترت

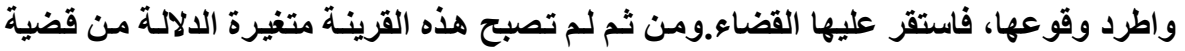

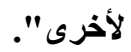

د/ عبد الرزاق السنهورى، الوسيط فى شرح القانون المدنى، الجزء الثانى، نظرية الالتزام بوجها.

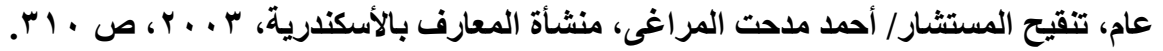


تتفق مع طبيعة الموضوع الذى اختاره وحدوده، ولما كان لموضوع الدراسـة أصل فى في

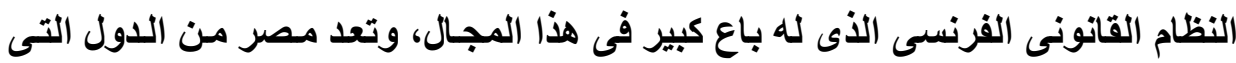

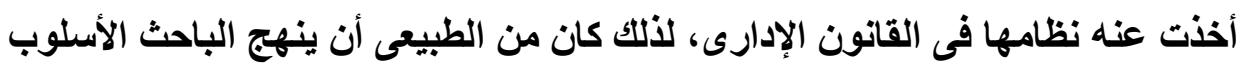

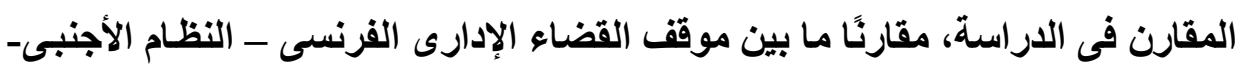

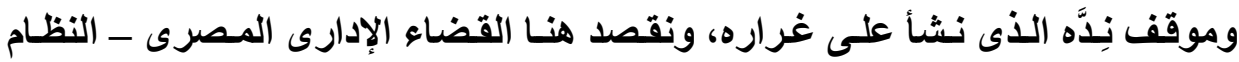
الوطنى.

وتوجب علينا طبيعة الاراسة - من جهة ثانية ـ اتباع المنهج التحليلى لتطبيقات القرائن القضائية ودورها فى الإثبات الإدارى على المستوى القضائى فى كل من فرنسا ومصر، مع رصد موقف الققه واتجاهاته من هذا. لالآدات

ونظرًا لكون القرائن متنوعة ومتعددة، فقد اهتم الباحث بـالقرائن القضائية،

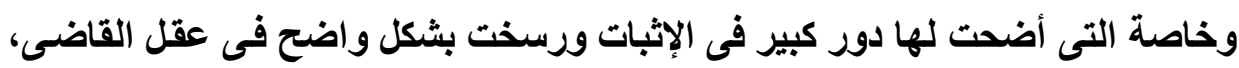
وتمثل أهمية بارزة فى مجال الإثبات، بهدف التخفيف من حدة عبء الإثبات ولثبات الواقع على الطرف الذى تعمل القرينة لصالحه.

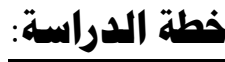

وفى سياق ماتقام، تناول الباحث موضوع الاراسة فى مباحث ثلاثة، على الوجه

$$
\text { المبحث الأول: مفهوم القرينة وأنواعها. }
$$

المبحث الثانى: الإثبات بالقرائن فى القانون الإدارى.

المبحث الثالث: تطبيقات للقرائن القضائية فى القضاء الإدارى. 


\section{المبحث الأول}

\section{هفهوم القرينة وأنواءها}

تقوم القرينة على الاستتباط سواء كان من قبل المشرع أو القاضى، فإذا كان

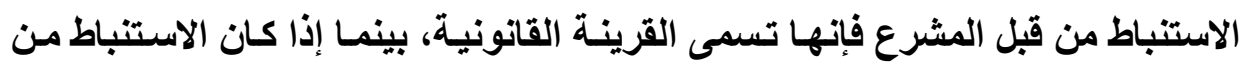
قبل القاضى فإنها تسمى بالقرينة القضائية. وفى ضوء ما تقدم نتناول هذا المبحث على النحو التالى: الاملب الأول: تعريف القرينة. المطاب الثانى: أنواع القرائن.

\section{المطاب الأول \\ تعريف القرينة}

تعل القرائن من طرق الإثبات المتقدمة التى يلجأ إليها القاضى وبشكل خـاص

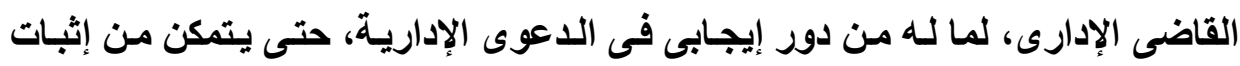

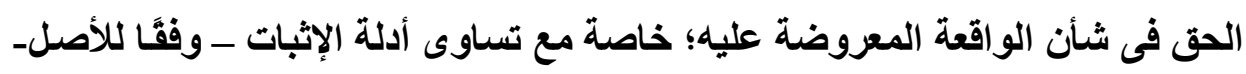

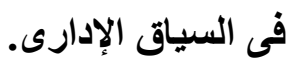

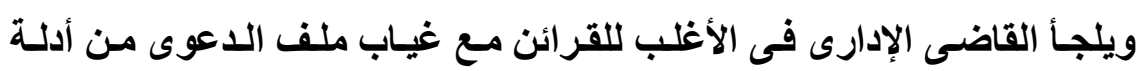
الإثبات الكافية، أو مع تعذر الطرف المكلف بالإثبات تقديم المستندات المؤيدة لإدعائه، 
أو فى حال تثكيكه فى الأدلة أو المستندات المقدمة أو حتى الأدلة المختلفة المقدمة، خاصة مع تو افر إمتيازات الإدارة فى مواجهة الطرف المقاب الدقابل فى الخصومة الإدارية.

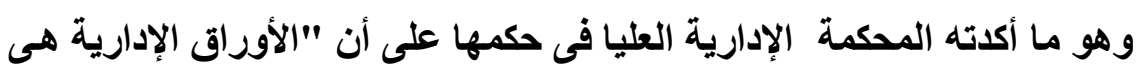

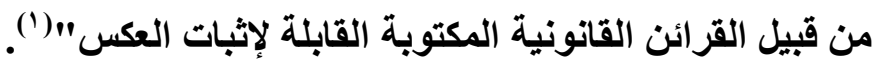
إذ أن الأوراق الإدارية إلا قرائن مكتوبة قابلة لإثبات العكس تتألف وتترابط مع

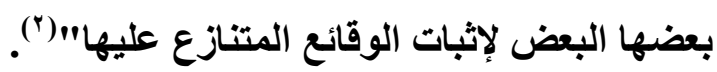
فالإثبات بالقرائن يمكن القاضى من الوصول إلى "الحقيقة إلى جانب وسـائل

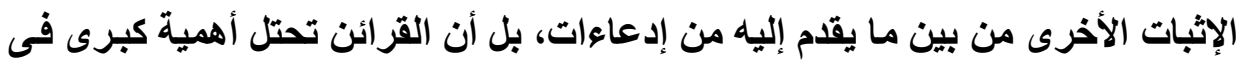

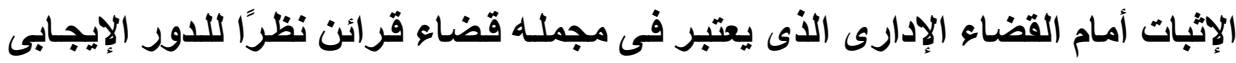

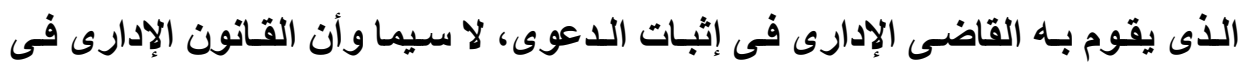

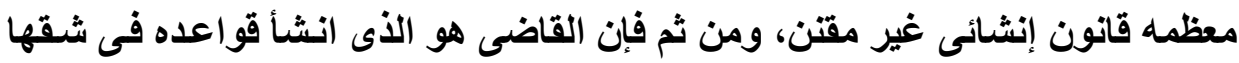

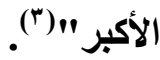

وهو مـا يدفعنا إلى ضرورة الإلمسام بتعرف القرينة، باعتبارهـا طريق مهم فى القى

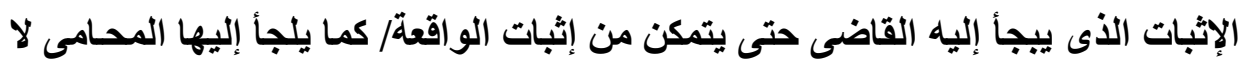
شكك لصرف الثثك عن موكله ونصرته، سواء أثشار إليها الثارع أو التى يستنبطها القاضى من أوراق وظروف الدعوى فى ضؤ ما يتمتع به القاضى من حرية فى الإثبات

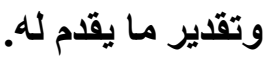

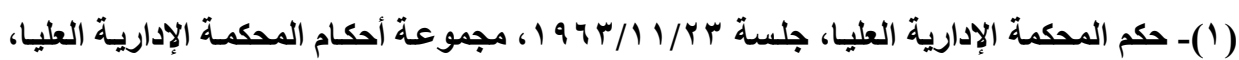

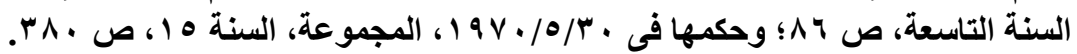

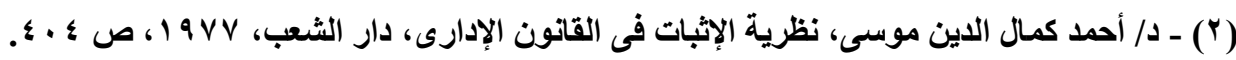

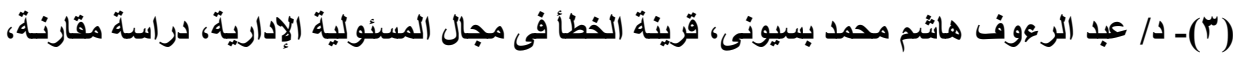

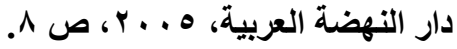


تعد القرينة فى المصطلح اللغوى جمع قرائن وهى مـا يستنبطه المشرع أو القاضى من أمر معلوم على أمر مجهول (').

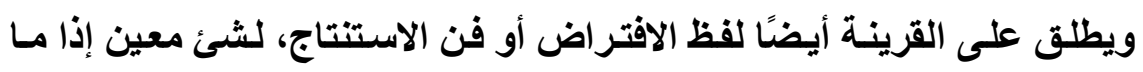

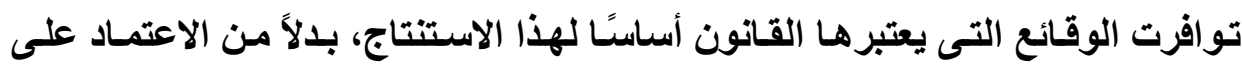
الوقائع والظروف المحتملة) (؟).

ويقال قرن الثئ بالثئ أى وصله له، واقترن الثئ بغيره أى صاحبه("). ويتضح من هذا، إن المعنى اللغوى للقرينة يتعلق بمفهوم الصلة والعلاقة بين آمرين أحدهما يستدل به على الآخر (؛).

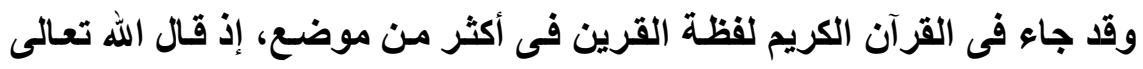

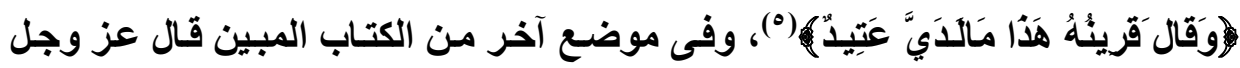

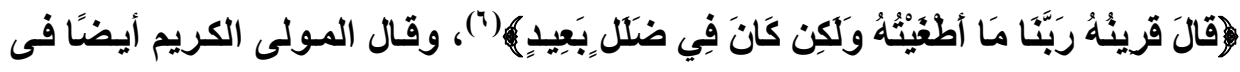

(')- د/ أحد مختار عمر، معجم اللغة العربية المعاصر، الطبعة الأولى، عالم الكتاب، ^ . . r، ص $.1 \mathrm{~A} \cdot \mathrm{T}$ (؟) (؟) - د/ المرجع السابق، ذات الموضع.

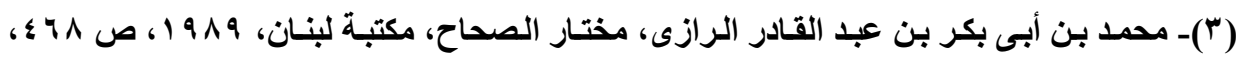
بن

(؛)- أحمد بن بكر بن منظور، لسان العرب، الجزء الحسادى عشر، الطبعة الثالثة، بيروت، دار إحياء

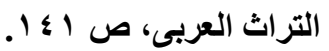
(†)- سورة ق، الآية سب. (†)- سورة ق، الآية VV الاية 


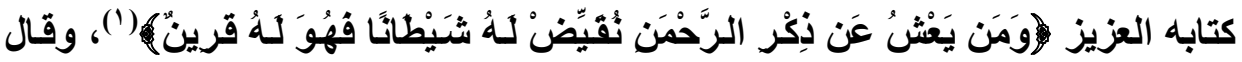

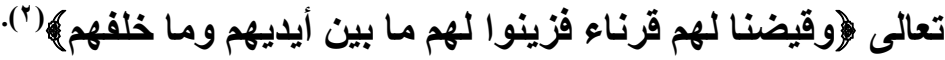
والقرينـة هـ المرأة تقول : قرينـة الرجل : امرأتهـ لمقارنته إياهـا " ويقول الراغب " الاقتران كالإذدواج فى كونه اجتماع شيئين أو أشياء فى معنى من المعانى

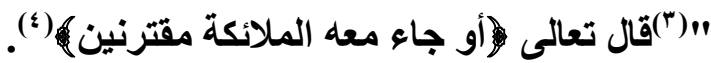
وقد عرف بعض أهل الفقه القرينة على أنها "كل إمارة ظاهرة تقارن شينًا خفيًا

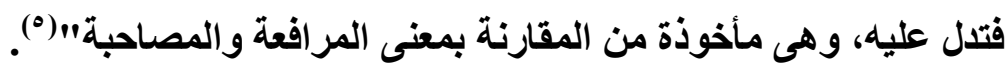
يبرز من ذلك أن القرينة تطلق فى اللغة على معان متعدة تدور حول المصاحبة

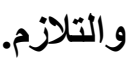

وتعرف القرينة فى المصطلح على أنها ما يستخلصه المشرع أو القاضي من

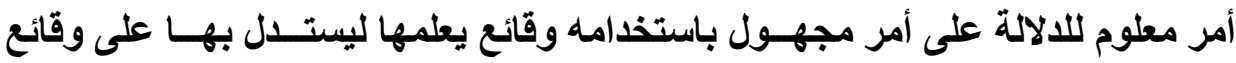
أخرى(")ـذات صـلة،ههي من الأدلة غيرا لمباباشرة التى تقوم على الاستنتاج وتنقسم القرائن إلى قرائن قانونية وأخرى قضائية. (v).

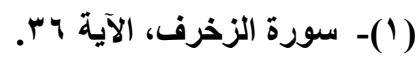

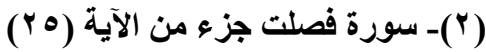

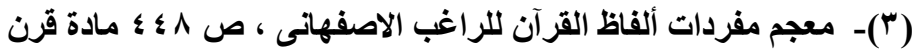

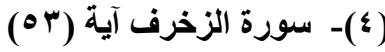

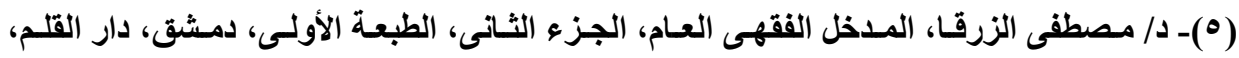

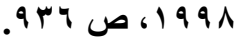

(ף) د د/عمر محمود حسن، العلم بالقرينة و أثره على الأحكام القضائية، المجلة القضائية، العدد الثامن،

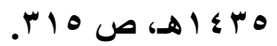
(V)- د/محمد طيب عمور، الإثبات بالقرائن القضائية بين الثريعة والقانون، مجلة الاكاديمية للاراسات

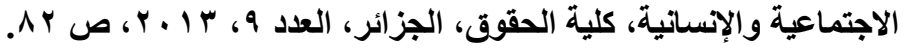


وقد عرف المشرع الفرنسى القرينة بصفة عامة فى المـادة 9 ؛ با أمن القانون

المدنى بأنها "النتائج التى يستحلصها القانون أو القاضى من واقعة معلومـة لمعرفة الفئة

$$
\text { واقعة مجهولة") (') }
$$

وفى مصر لم يشر المشرع بشكل قاطع إلى تعريف القرينة واكتفى بالإشسارة إلى

أنواع القرائن، بالنص على القرائن القانونية فى المادة 9 و من قانون الإثبات، والقرائن القضائية فى المادة ... 1 من نفس القانون.

وتعرف محكمة النقض المصرية القرائن بأنها "استنباط أمر مجهول من واقعة

ثابتة معلومسة بحيث إذا كانت هذه الواقعة محتملة، وغير ثابتة بقين فإنها لا تصلح

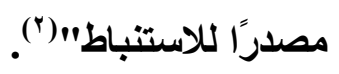

ولا تختلف القرائن فـ القـانون الإدارى عنهـا فـى القـانون المـدنى إذ عرفها

البعض بأنها "شواهد وإمارات نص عليها المشرع أو استتبطها القاضى من الواقعة

المعروضة عليه تؤيد المدعى فى دعواه أو تخذله"(").

وقد أبرز قضاء مجلس الاولة المصرى دور القرائن فى الإثبات، فأرسى العديد

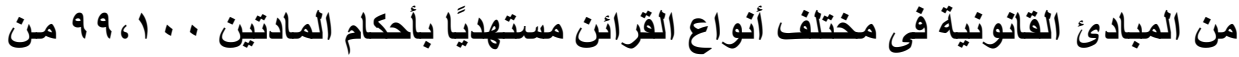
قانون الإثبات، فقد قضى بأن "رقابة القضاء الإدارى لقيام السبيفى القرار بالفصل غير فير

$$
\text { (1) - وجاء نص المادة 9 ؛ ب } 1 \text { مدنى كالتالى: }
$$

L'article 1349 du C.Civ dispose que les présomptionssont les conséquences que la loi ou le magistrat tire d'un fait connu à un fait inconnu.

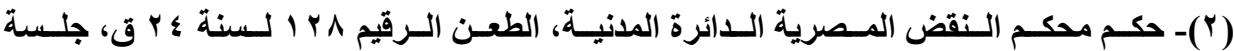

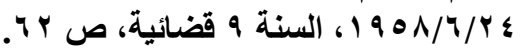

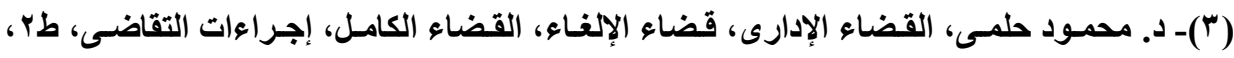

$$
\text { . }
$$


التأديبى لا تعنى أن يحل نفسه محل جهة الإدارة فيمـا هو متروك لتقديرها ووزنها في ستأنف النظر بالموازنة والترجيح فيما قام لايها من دلائل وبيانات وقرائن أحوال إثباتًا

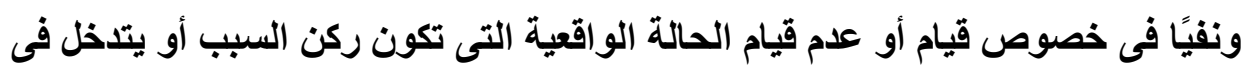

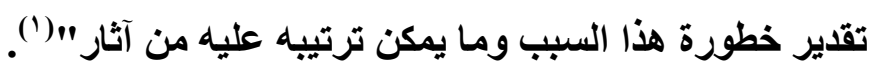

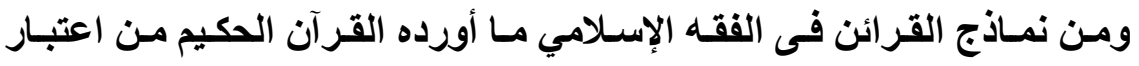

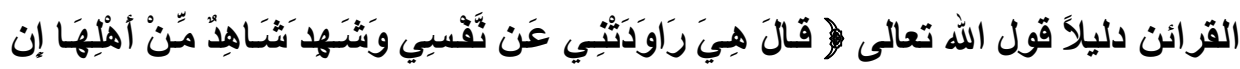

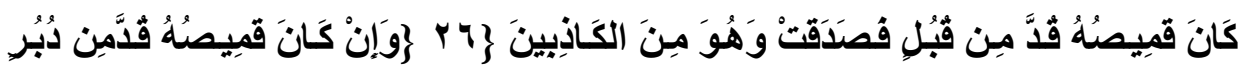

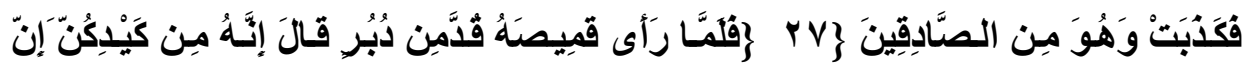

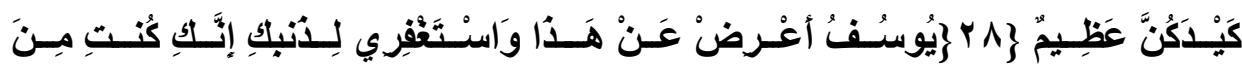

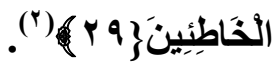

فقد وقع خلاف بين سيدنا يوسف عليه السلام وامرأة العزيز، وكلاهما يتهم الآخر أنه راوده عن نفسه دون أن يكون هناك دليل على مـا يدعيه، فشهد شـاهد من فئن

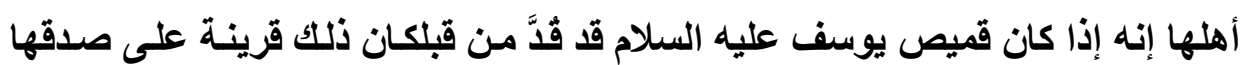

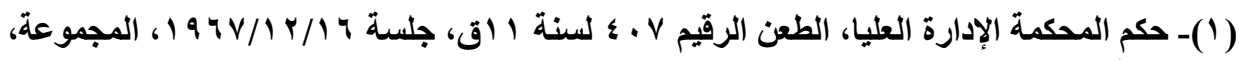

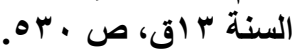

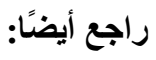

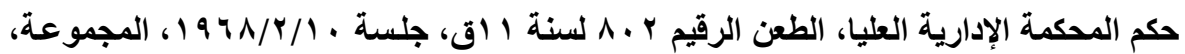

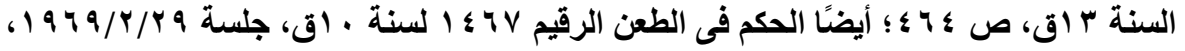

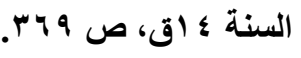
راجع فى هذا:

دالكدى ياسين عكاثة، موسوعة القرار الإدارى، فى قضاء مجلس الدولة، منشأة المعارف

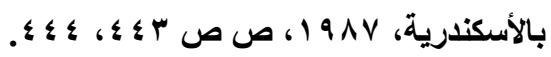

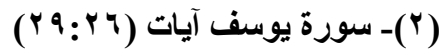


وإن كان قَُّ من دبر فإن هذه قرينة على كذبها وصدقه، وقد تبين أنه قد قدَّ من دبر

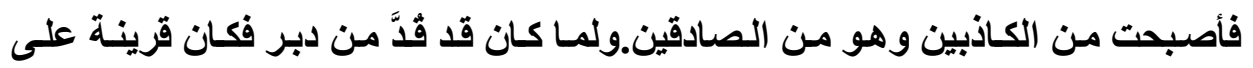

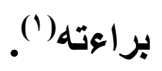

وقد عرفها الجرجانى بأنها "أمر يثير إلى المطلوب"(")، وعرفها البعض من

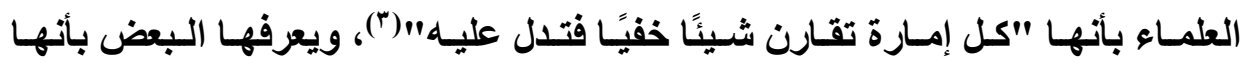
"الإمارة التى نص عليها الشارع أو استتبطها أنمـة الثريعة باجتهادهم أو استنتجها القاضى من الحادثة وظروفها وما يكتنفها من أحوال"( ().

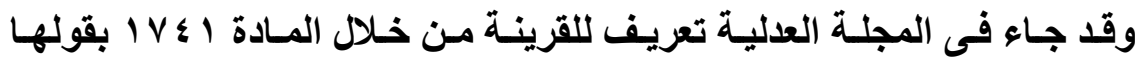

"القرينة القاطعة هى الإمارة البالغة حد اليقين".

ويعيب على هذا التعريف أنه مقصور على تعريف القرينة القاطعة فقط، بينما

القرينة قد تكون قاطعة أو قد تكون بسيطة (ْ).

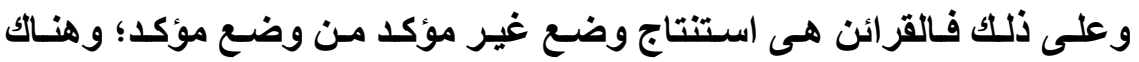

نوعان من القرائن سنتناولها فى المطلب القادم بشئ من التفصيل المناسب.

(1)- د.فوزيـة عبد الستار، القضاء فـى الإسـلام، الطبعة الأولى، مركز الأهرام للنشر والترجمـة

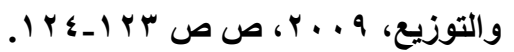

(r) - على بن محمد بن على الجرجانى، التعريفات للجرجانى، ضبطه محمد بن عبد الحكيم القاضى،

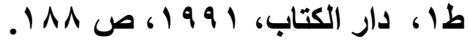

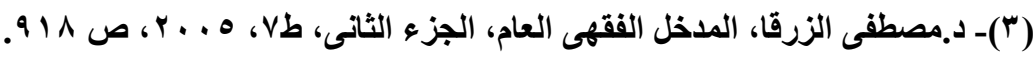

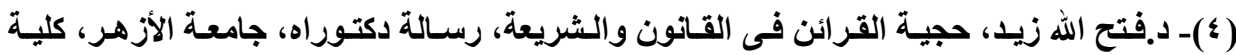

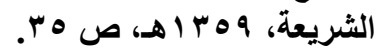

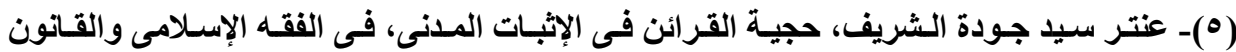

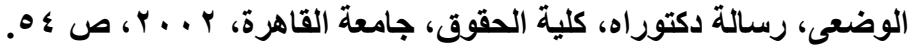




\section{المطلب الثانى}

\section{أنواع القرائن}

كمـا تبِين لنـا سـلقًا أن القرائن أمـر مجهول يستتيط مـن أمـر معلوم، ويمكن حصر القـرائن فـى نـوعين، وهـى القـرائن القانونيـة والقـرائن القضـائية؛ فـإذا كـان الاسـتنباط مـن قبـل المـنظم أو المسشرع كانــت القرينـة قانونيـة، وإذا كـان الاسـتنباط من قبل القاضى ووقائع وملابسات الدعوى ومناقشة الثهود أو الخصوم كانت القرينة قضائية. وسوف نتناول هذا المطلب فى فرعين على التحو التالى: الفرع الاول: القرائن القانونية. الفرع الثانى: القرائن القضائية.

\section{الفرع الأول \\ القرائن القانونية}

عرف المشرع الفرنسى القرائن القانونية فى المـادة ـ هـ امن القـانون المدنى بأنها هى التى "يجعلها نص القانون تتعلق بتصرفات أو وقائع معينة " مثل التصرفات التى يقرر القانون أنها باطلة مفترضًا إبرامها للاحتيال على أحكامه؛ ومثل الأحوال التى يقرر فيها القانون أن كسب الملكية أو براعة الأمة تنتج عن بعض ظروف معينة؛ ومثل 
الحجية التى يفترضها القانون على الأمر المقضى؛ ومنها أيضًا القوة التى يفرضها

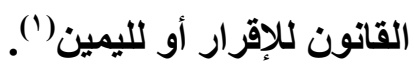

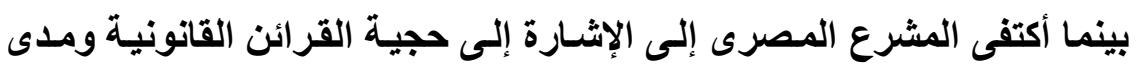

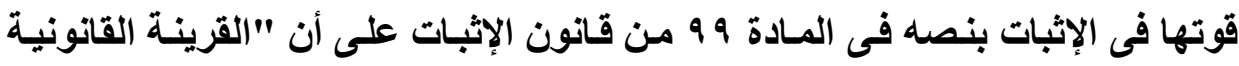

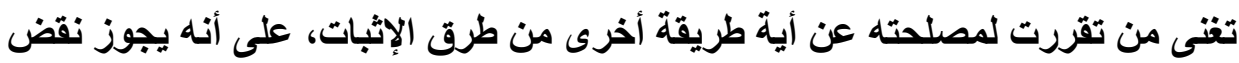

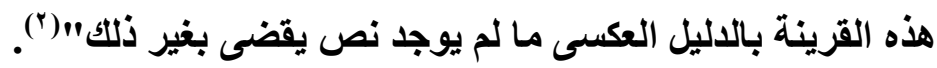

وتعتبر القرينـة القانونية هى التى نص عليها القانون صراحة، وهى ليست

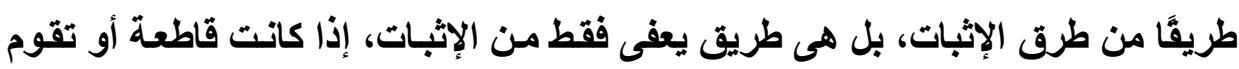

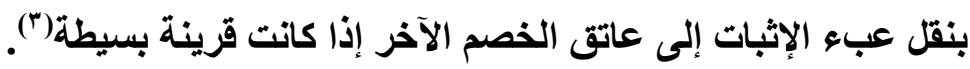

(1) La présomptionlégaleest (Article 1350 du Code civil ) celle qui estattachée par uneloispéciale à certainsactesou à certainsfaits; tels que:

$1^{\circ}$ Les actes que la loidéclarenuls, commeprésumésfaitsenfraude de ses dispositions, d'aprèsleurseulequalité ;

$2^{\circ}$ Les cas dans lesquels la loidéclare la propriétéou la libérationrésulter de certainescirconstancesdéterminées ;

$3^{\circ} \mathbf{L}$ 'autorité que la loiattribue à la chose jugée ;

$4^{\circ}$ La force que la loiattache à l'aveu de la partieou à son serment.

$$
\begin{aligned}
& \text { (Y)- ومن أحكام قضاء النقض فى هذا السياق، "وضع يد المشترى على العين المبيعة قرينة على }
\end{aligned}
$$

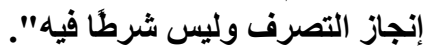

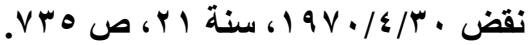

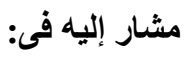

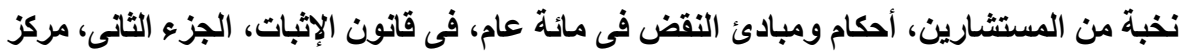

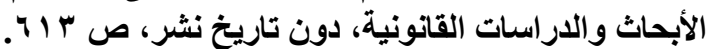

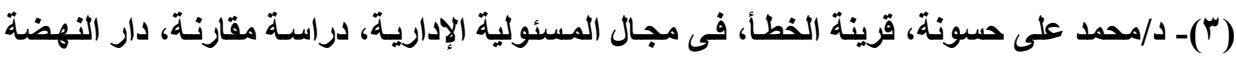

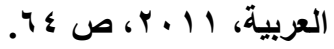


كما هو الحال بالنسبة لحجية الأمر المقضى به، إذ تنص لمـادة 1 ـ 1 من قانون الإثبات على أن "الأحكام التى حازت قوة الأمر المقضى تكون حجة فيما قضت فيه من الحقوق، ولا يجوز قبول دليل ينقص هذه الحجيـة، ولكن لا تكون لتلك الأحكام هذه الحجية إلا فى نزاع قام بين الخصوم أنفسهم دون أن تتغير صفاتهم وتتعلق بذات الحق

$$
\text { محلاً وسبيًا. }
$$

وكما هو الثأن بالنسبة لقرائن المسئولية التى نص عليها المشرع المدنى مثل المسئولية عن حراسة الأشياء أو فعل الحيوان أو مسئولية المتبوع عن أعمسال تابعه. وتقضى المحكمة بهذه الحجية من تلقاء نفسها".

\section{وترجع العلة هن تقريز القرائن القانونية إلى: (1)}

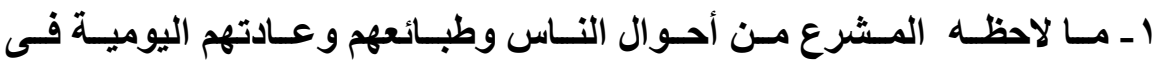

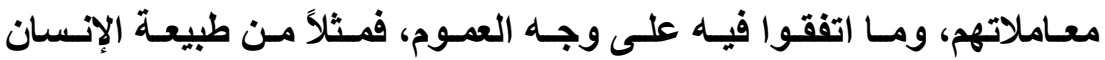
وعاداته أن لا يترك سند دينه للمدين إلا إذا أخذ دينه، فإذا ما وجد سند الدين تحت يــ المدين كـان ذلك قرينـة على تخلصه مـن الدين، وهو مـا يعنى أنها تقررت مراعاة لمصلحة الناس. r ـ مر اعـاة الشارع للمصلحة العامـة كقرينـة قوة الشئ المحكوم فيـه، إذ تقضى المصلحة العامـة باعتبـار الحكم النهائى قرينـة على صحة مـا قضى بـه لمنـع تجدد النزاع بلا حد ولا نهاية.

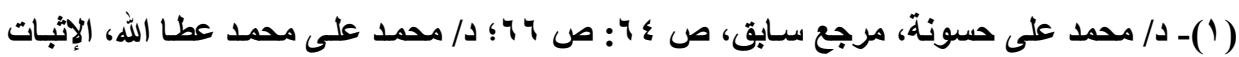

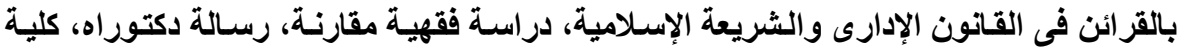

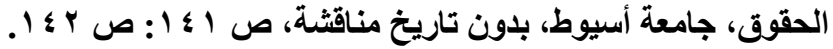


rــ خوف الثارع من مخالفة الأحكام التى قررهـا، فمثُلا لا تصح الوصية لوارث،

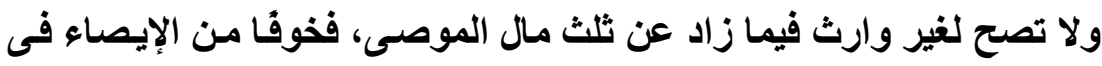

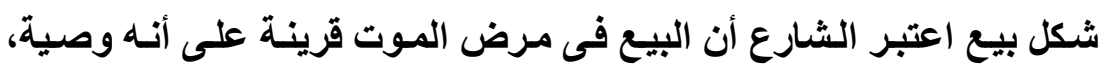

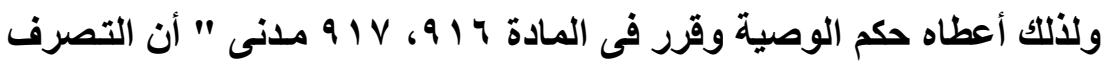

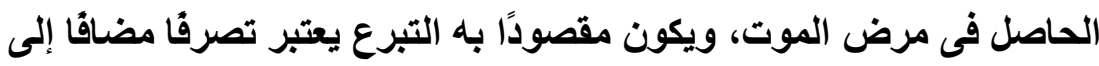

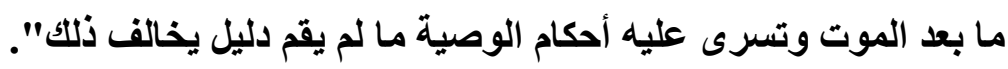
ع ـ مراعاة الثارع لمصلحة خاصة، أخذا بظواهر الأمور وتيسيرًا للمعاملة بين

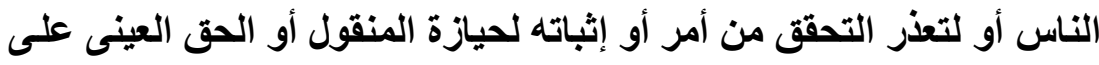

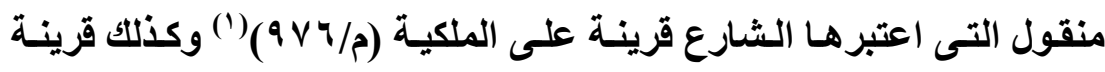
خطأ المتبوع المفترضة عندما يخطئ الخادم أو التابع (م/ع ال IV). ولا شك أن هذه العلة التى من أجلها قرر المشرع القرينـة القانونية فى نطاق القانون المدنى توجد فى نطاق القانون الإدارى أيضا ومن الأمثلة على ذلك الك : أـ مثال القرينة القانونية التى تقررت مراعاة للمصلحة العامة. ما قضت بـه المحكمة

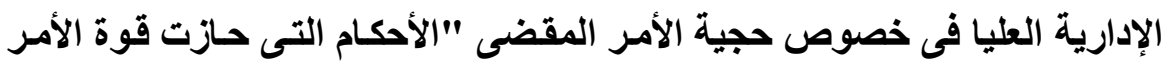

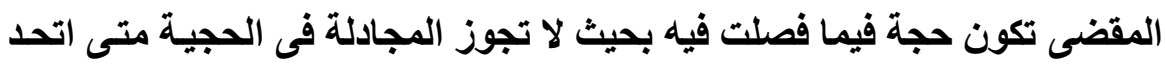

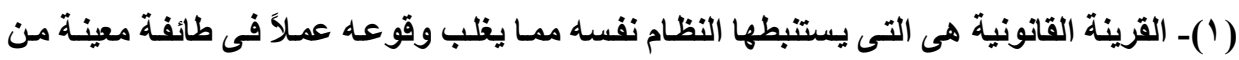

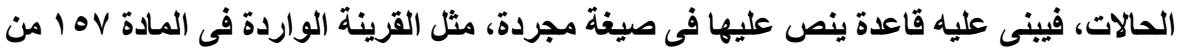

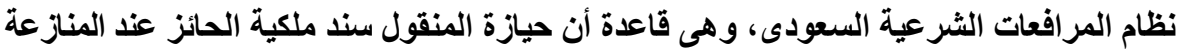

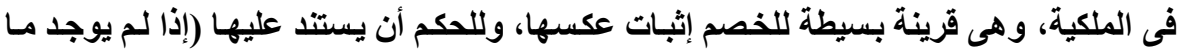

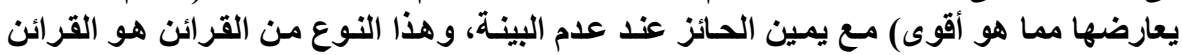
القانونية. عبد الفتاح سليمان، المبسط فى شرح نظون نظام المر افعات الشرعية فى المملكة العربية السعودية،

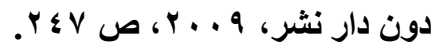


الخصوم، والموضـوع ، والسبب ، بـل يعتبر الحكم عنـوان الحقيقة فيمـا قضى، والأى يحوز الحجية من الحكم هو منطوقه ، وكذا الأسباب الجوهريـة المكملـة لـه له

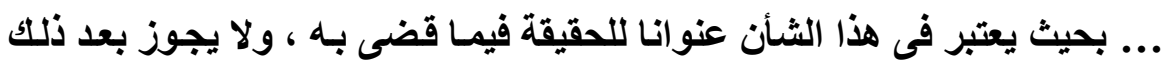

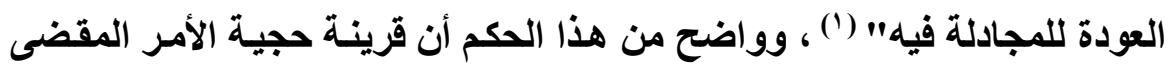

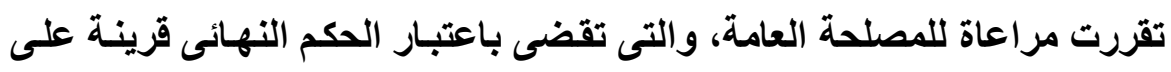
صحة ما قضى بهله بهدف منع تجدد النزاع . بـ مثال القرينة القانونية التى تقررت مراعاة لمصلحة خاصة ... ما قضت به محكمة القضاء الإدارى فى خصوص قرينة مسئولية الإدارة عن أعمال موظفيها. "ومـن حيـث إن إقرار الحكومـة بمسئوليتها عن التعويض يرفع عنـه "أى

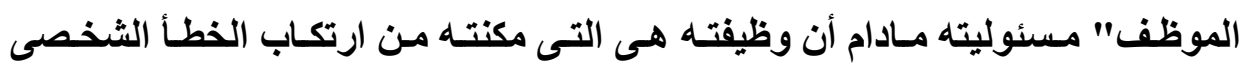

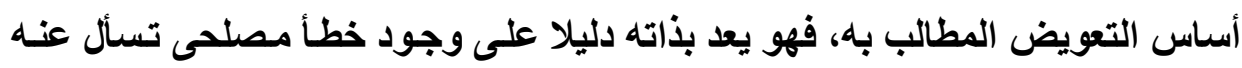

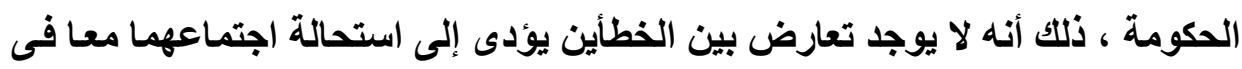

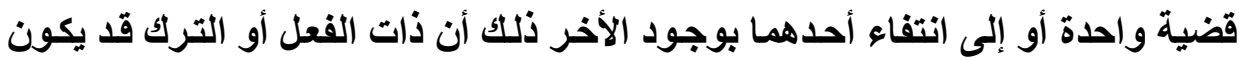
خطأ شخصيا ومصلحيا فى الوقت ذاته، إذ يعد الخطأ الثخصى متى وقع من الموظف

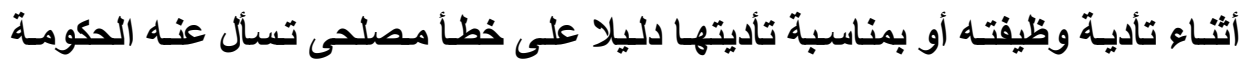
لإهمالها فى الرقابة والإشر اف على موظفيها وعلى ذلك فليس فى القانون ما يمنع قيام

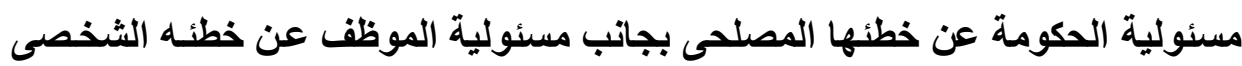

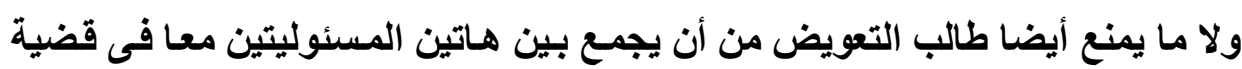

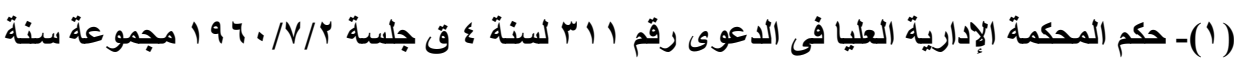
. 11 : 0

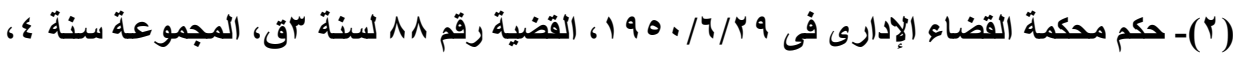
ص 904. 
ففى هذا الحكم نجد أن المشرع قرر مسئولية الحكومة عن أعمال الموظف بنـاء

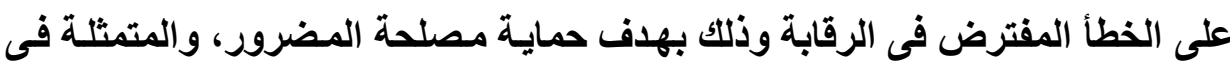
عدم ضياع التعويض المستحق له نتيجة إعسار الموظف ('). وعلى ذلك حتى يمكن العمل بالقرينة القانونية أمسام القضاء فلابد من تو افر

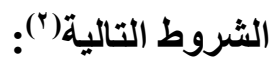

1 - أن يوجد نص قانونى يقر القرينة فى فى حالة توافر واقعة معينة.

$$
\text { r- بيان الأمور التى بنيت عليها القرينة. }
$$

r- أن تكون القرينة صالحة للتطبيق على الحالة المعروضة.

تنقسم القرائن القانونية سواء فى القانون الفرنسى أو المصرى إلى

\section{النوع الأول: القرائن القانونية البسيطة:}

هى القرائن القانونيـة غير القاطعة التى يمكن اثبـات عكسها، ويطلق عليها

القرينة القانونية البسيطة والتى تعفى من تقررت لمصلحته من عبء الإثبات كمـا تنقل عبء الإثبات من الخصم الذى تقررت لمصلحته إلى الخصم الآخر (").

(1)- محمد عطا الله، مرجع سابق، ص ب ؟ أ.

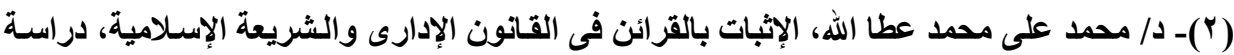

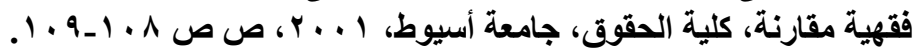

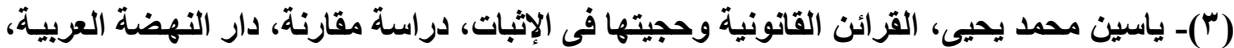
. 01 (199. 


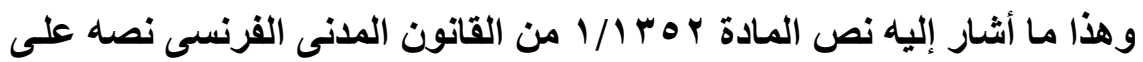

"القرينة القانونية تغنى من تقررت لمصلحته عن أى دليل"(').

ومن هذه القرائن البسيطة، اعتبار حيازة الثئ المنقول قرينة على ملكية الثئ،

كما اعتبر المشرع أن الحيـازة قرينـة على وجود السبب الصحيح وحسن النيـة مـا لم

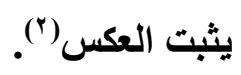

فالحيـازة فى ذاتها قرينة على وجود السبب الصحيح وحسن التية مـا لم يقم

$$
\text { الاليل على عكس ذلك. }
$$

ويجوز إثبات أن حق الملكية مثثقلاً بتأمين عينى كحق انتفاع أو حق ارتفـاق؛

كذلك يجوز للتاجر أن يثبث أن التصرف القانونى الصادر منـه منقطع الصلة بنشاطه التجارى. كما يجوز إثبات أن الحائز سـئ النية، وأن السفينة لـم تفقد على الرغم من انقطاع اخبار ها لمدة معينة(").

ومن الأمثلة على القرائن القانونية البسيطة ما نصت عليه المادة ؟ ب من قانون

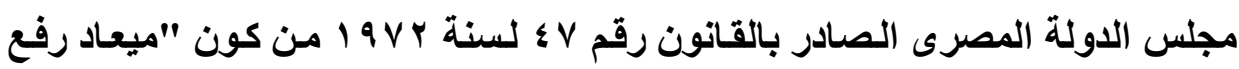
الدعوى أمسام المحكمة فيمـا يتعلق بطلبـات الإلغـاء ستون يومـا من تـاريخ نشر القرار الإدارى المطعون فيـه في الجريدة الرسـية أو في النشرات التـى تصدرها المـصالح العامة أو إعلان صاحب الثأن به ـ.

(1) - L'article 1352/1:

"la présomptionlégale dispense de toutepreuvecelui au profit duquelelleexiste".

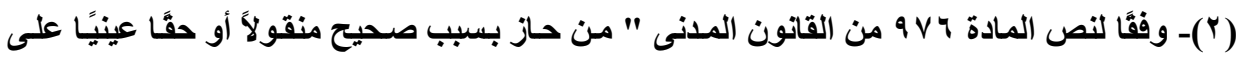

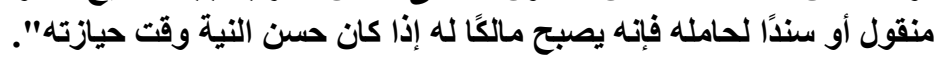

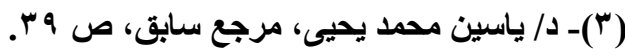


......، وإذا صدر القرار بالرفض وجب أن يكون مسببا ويعتبر مضى ستين يومـا على تقديم التظلم دون أن تجيب عنه السلطات المختصة بمثابة رفضه. ويكون ميعاد رفع الدعوى بـالطعن في القرار الخـاص بـالتظلم ستين يومـا من

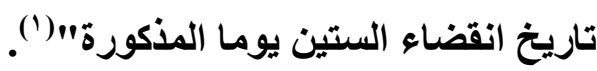

\section{النهوع الثانى: القرائن القانونية القاطعة:}

الأصل فى القرائن القانونية أنها بسيطة تقبل إثبات العكس بكافة الطرق، ولكن

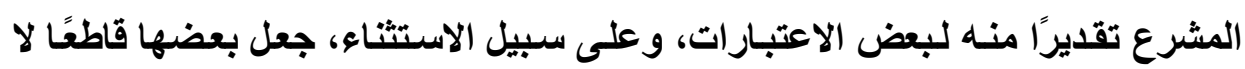
يجوز إثبات عكسه.

القرائن القاطعة هى التى لا تقبل إثبات العكس، كقرينة الملكية المستفادة من وضع اليل المدة الطويلة، وقرينة العلم بالقانون بعد النشر فى الجريدة الرسمية، وقرينة قوة إنة

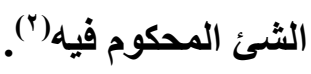

وإذ قلنا أن القرينة القانونية القاطعة لا تقبل إثبات العكس فليس معنى ذلك أنها لا تدحض أبدًا، ذلك أن عدم القابلية لا يكون إلا للقواعد الموضوعية، أما القرائن القانونية ولو كانت قاطعة فهى قواعد إثبات لا قواعد موضوعية فهى إذن لا تستعصى على أن

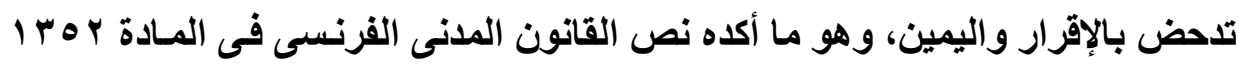
بالنص على "القرينة القانونية تغنى من تقررت لمصلحته عن أى دليل ولا يجوز إثبات مـا ينقض القرينـة القانونيـة إذا كـان القانون يبطل على أسـاسـها بعض التصرفات، أو لو

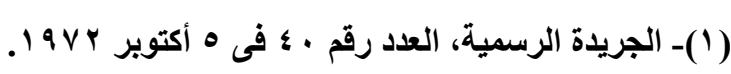

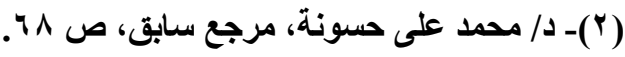


يجعل الاعوى غير مقبولة، هذا مـا لـم يحفظ القـانون الحق فى إقامـة الدليل العكسى، وذلك مع عدم الإخلال بما سيتقرر فى خصوص اليمين والإقرار القضائيين". ومن الجدير بالذكر أن المسؤول مسؤولية قائمـة على قرينـة قانونية قاطعة، وإن كان لا يستطيع إثبات عكس هذه القرينة إلا أنه يستطيع دحضها بـالإقرار الصادر من الخصم أو باليمين الموجه إلى الخصم فينكل ('). ويجد هذا النوع من القرائن تطبيقه بشكل بارز فى نص المـادة V V من القانون

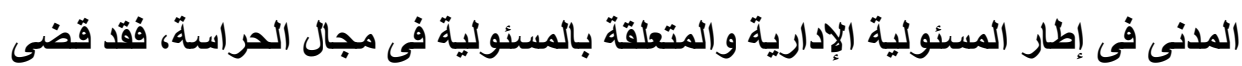
قضاء مجلس الدولة أن "كابل الكهرباء المخصص لإنارة الطريق هو من الأشياء التى

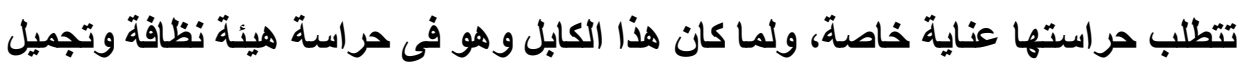

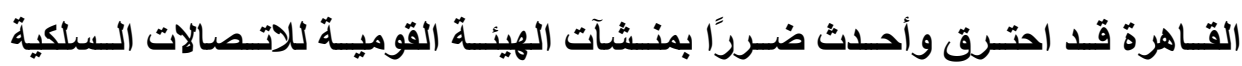
واللاسلكية، فإن الهيئة الأولى تلتزم بتعويض هذه الأضرار، ولا يعفيها من المسئولية إلا إثبات أن هذا الاحتراق كان بسبب أجنبى" (). ومسن أمثلتهـا أيضًا قرينـة مسئولية الإدارة عن الأشسياء الخطرة الموجـودة فيى حراستها، إذ تقوم المسئولية على أساس الخطأ فى الحراسة، وهو خطأ مفترض لا يقبل

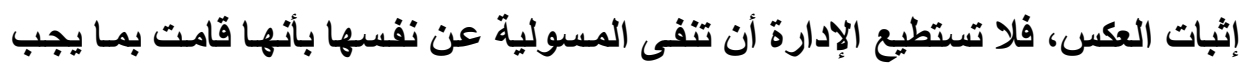
عليها من العناية بالثئ أو أنها بذلت ما فى وسعها لمنع وقوع الضرر (").

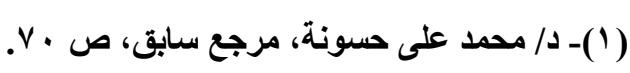
(ץ)

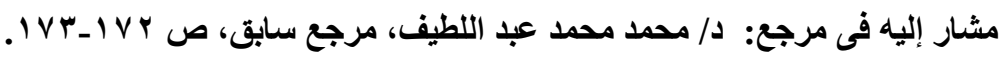

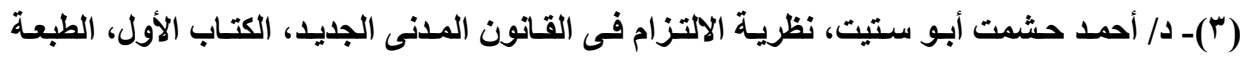

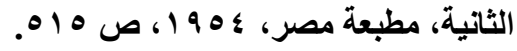




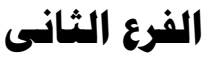

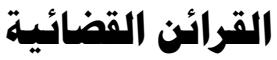

القرائن القضائية هى التى يستنتجها القاضى من وقائع الدعوى وملابساتها

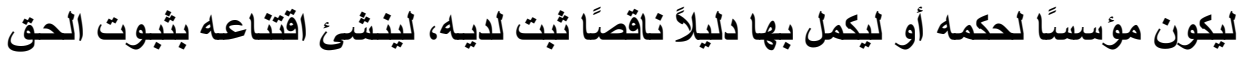
بإصدار الحكم، على ان يبين وجه دلالة القرينة (') والأصل فى القرينـة القانونيـة إنها قرينـة قضائية "تـواترت وأطرد وقوعـه. فاستقر عليها القضاء. ومن ثم لم تصبح هذه القرينة متغيرة الدلالة من قضية إلى فئ

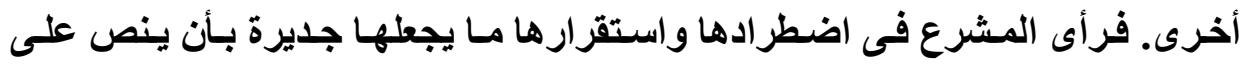

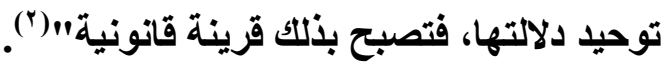
ولذلك تمثل القرائن القضائية وسيلة هامـة فى الإثبات الإدارى يستطيع بها

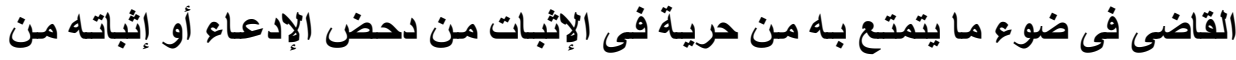

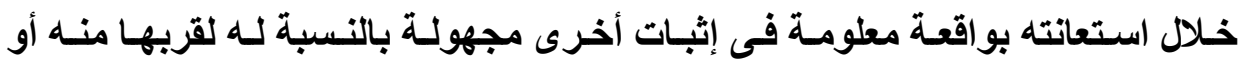

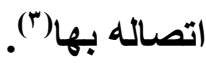
و هو ما أشار إليه التقنين المدنى القرنسى فى المادة بهه ا بنصه أن "القرائن التى لم ينص عليها القانون تترك لنظر القاضى وتقديره، ولا يجوز أن يأخذ إلا بقرائن

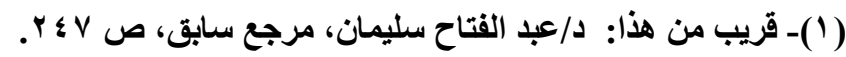

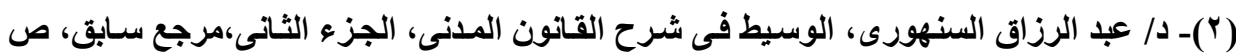

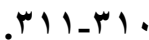

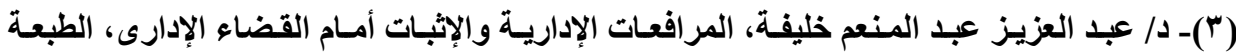

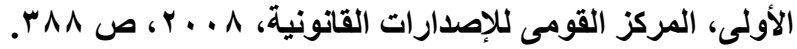


قوية الدلالة دقيقة التحديد، ظاهرة التوافق، ولا يؤخذ بها إلا فى الأحوال التى يجيز فيها قانون الإثبات بالبينة، ما لم يطعن فى التصرف بالغش أو التدليس(')

وأكات المادة . . 1 من قانون الإثبات المصرى على أن "يترك لتقدير القاضى استنباط كل قرينـة لـم يقررهـا القانون، ولا يجوز الإثبات بهذه القرائن إلا فى الأحوال التى يجوز فيها الإثبات بشهادة الثهود". ويطلق على هذه القرائن أيضًا القرائن الموضوعية لانها تستتبط من موضوع

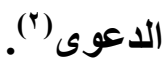
ويتمتع قاضى الموضوع بسلطة مطلقة فى استنباط القرائن القضائية، وفقَا لمـا تبين مـن نـص المـادة ـ . 1 أن الأمـر متروك للقاضسى لاستتباط كل قرينـة لـم يقررهـا القانون. فالقرائن القضائية إذا يترك أمر استتباطها للقاضى فهو يختار واقعة معلومة فى

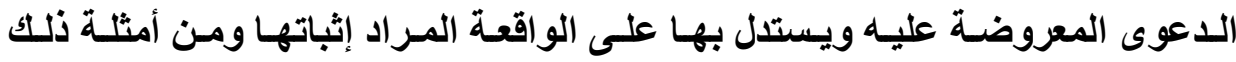
استخلاص صورية التصرف من واقعة القرابة، فإذا طعن الدائن بالصورية فى التصرف الذى صدر مـن مدينـه فإنـه قد يستتد فى تأييد دعواه إلى أن هنـاك واقعة قرابـة ببين المتصرف والمتصرف إليه. وفى هذه الحالـة قد يستخلص القاضى من واقعة القرابـة قرينة على صورية التصرف، فالواقعة الثابتة فى هذا الفرض هى واقعة القرابة، وهى هـ

(1) "Les présomptions qui ne sont point établiespar la loi, sontabandonnées aux lumières et à la prudence du magistrat, qui ne doitadmettre que des présomptions graves, précises et concordantes, et dans les casseulementoù la loiadmet les preuvestestimoniales, à moins que l'acte ne soitattaqué pour cause de fraudeou de dol".

(Y)- د/ سليمان مرقص، أصول الإثبات فى المواد المدنية، الطبعة الثانية، . 99 19، ص ؟1. 
التى يستنتج منها القاضى قرينة غير مباثرة لأنها ينصب على واقعة أخرى مجاورة ومتصلة بموضوع النزاع يؤدى ثبوتها إلى ترجيح ثبوت الواقعة محل النزاع'"). وتنعقد القرينة القضائية بتوافر ركنين، هما على النحو التالى: أولاً: الركن المادى:

و واقعة ثابت ينتقيها القاضس من ظروف وملابسات الدعوى(")، وتعد بمثابة الدلانل أو الإمارات أو العلامات ـلاستتباط الواقعة المجهولةــ التى يتحقق القاضى من

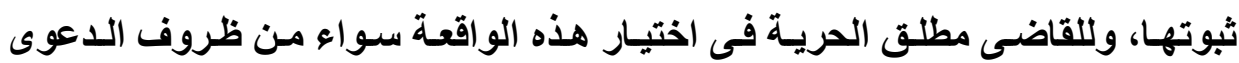

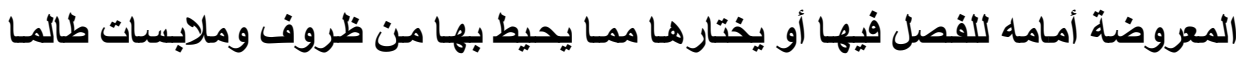
كانت على صلة بموضوع النزاع المعروض عليه("). ونـرى ضـرورة أن تكـون هـذه الواقعـة الثابتـة منتجـة فـى استتباط الواقعـة المجهولة، وإلا فقلت دلالتها وأهيتها وأصبحت مجرد واقعة عادية لا يمكن الاستناد

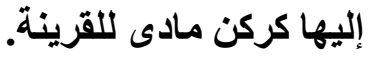
و هو مـا أكلتهه محكمة النقض بقولها "وأنـه و إن كـان لا تثريب على محكمـة الموضوع أن تأخذ في معرض الإثبات بالقرائن إلا أن ذلكت مشروط بأن تكون القرائن التى عولت عليها تؤدى إلى ما انتهت إليه"(؛)

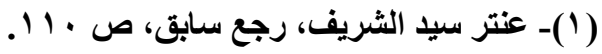

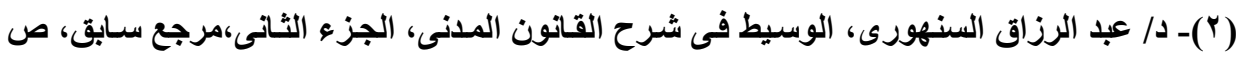

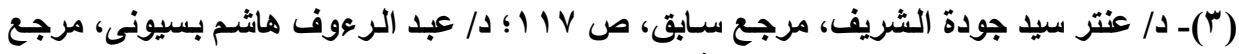

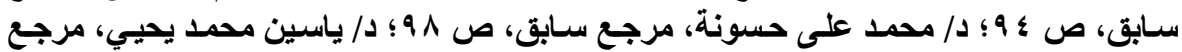
$=$ 
ومـن القرائن القضائية التى استتـل إليها قضاء مجلس الدولـة اعتبـار دخول البضائع إلى البلاد مـن خلال الـائرة الجمركيـة هو بمثابـة قرينـة قضائية على سـاد الرسوم الجمركية عنها، ما لم تثبت الإدارة عكس ذلكف(')

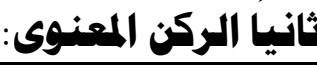

الاستتباط الذى يقوم بـه القاضسى لاستخلاص الواقعـة الخفيـة والمجهولـة مـن

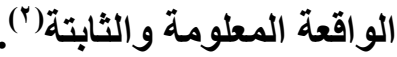

ومـن الجدير بالتنويـه أن القاضسى لـه سـلطة واسـعة فى تقدير مـا تحملـه هـذه

الواقعة الثابتة من الدلالة طالمـا بنى علمسه على أمور سـائغة مؤديـة عقلاً إلى النتيجة التى ينتهى إليها فى حكمه، ويظلب وقو عها فى ذات الظروف والملابسات؛ولذلك يستنتج من القرينة الثابتة فى الغالب ما هو راجح الوقوع(") فهى فى الأغلب علم ظنى يحيطه الاحتمال والترجيح.

المستثـار/ محمد عزمى البكرى، موسوعة الفقه والقضاء في قـانون الإثبات، في المواد المدنية

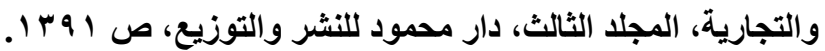

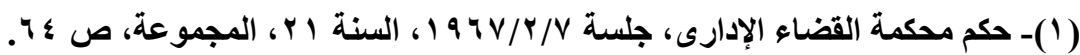

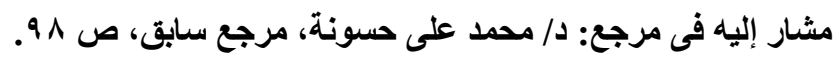

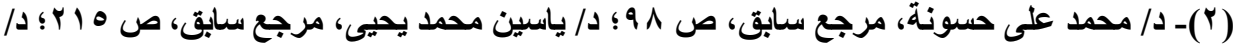

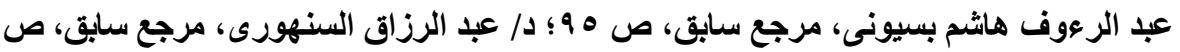

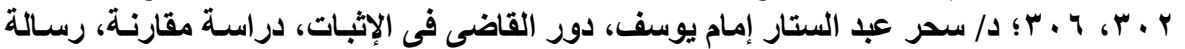

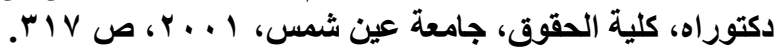

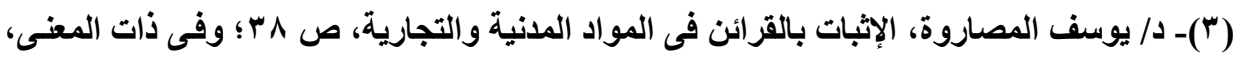

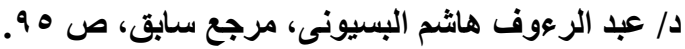


وقد نظم المشرع القرائن القضائية فى نص المـادة . . . مـن قانون الإثبات بنصه"يترك لتقدير القاضسى استتباط كل قرينه لـم يقررهـا القانون، ولا يجوز الاثبـات بهـذه القرائن الا فـى الأحسوال التـى يجـوز فيها الاثبـات بشهادة الشهود"؛؛ فـالقرائن القضائية تتساوى فى منزلتهـا مـع البينة، ولا يجهوز الإثبات بقرينـة قضائية إلا حيث يجوز الإثبات بالبينة(')، وبالتـالى القرائن القضائية تجوز فى إثبات الوقائع المادية،

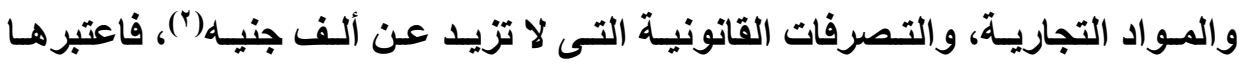
المشرع مـن الادلـة المقيدة التـى لا يجـوز الإثبـات بهـا فـى جميـع الأحسوال للحـد مـن خطرها(") لأن الإثبات بالقرائن كما تبين لنا يخلو فى كثير من الأحيان من اليقين حيث أن لها دلالة غير قاطعة.

وفى هذا يقول الاكتور السنهورى "...وهذا هو الاستنباط، وفيه تختلف الأنظار، وتتفاوت المدارك، فمن القضاة من يكون استنباطه سليمًا فيستقيم له الدليل، ومنهم من يتجافى استنباطه مع منطق الواقع، ومن ثم كاتت القرينة القضائية من أسلم الأدلة من حيث الواقعة الثابتة التى تستنبط منها القرينة، ومن أخطرها من حيث صحة الاستنباط

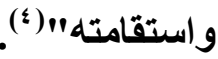

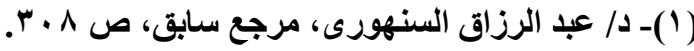

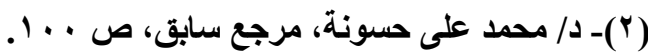

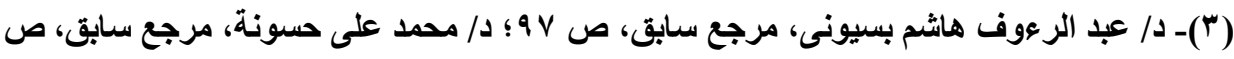

$$
\begin{aligned}
& .1 \text {. }
\end{aligned}
$$

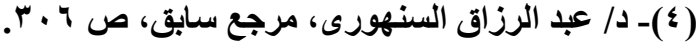

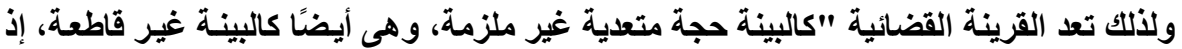


وبذلكك تعد القرينة "التى يتخذها القاضسى أساستًا للاستتباط منهـا لا تعطيه إلا علمًا ظنيًا تختلف فى تأويله الأنظار وتتفاوت فى الاستنباط منـه المدارك، ولذا لا يكون الطعن أمام المحكمة العليا فى حكمه مقبولاً إلا إذا بنى على خطئه فى تأويل القرينة التى لى التى

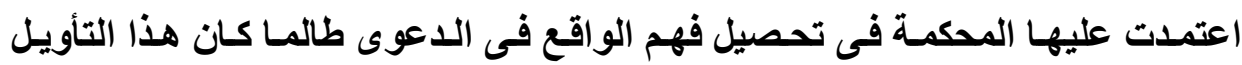

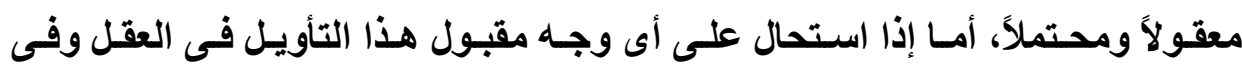

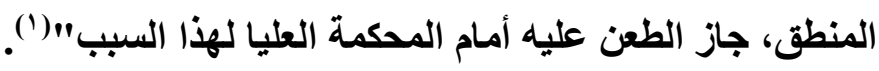
وكسان مـن مقتضى هـذا الـركن أن الاحتجــاج بالقرينـة أمسام القضاء أو تمسكك القاضـى بهـا يتطلب الاتـصلال بـين القرينـة والواقعة محل الإثبـات، ولا يكفى مجرد

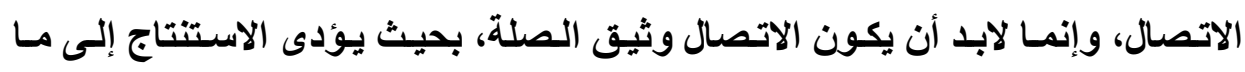

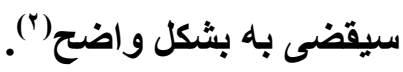
ومن الجدير بالتنويه، إن القرينة القضائية والقرينة القانونية من "طبيعة واحدة مـن حيث التكييف والتأصيل، إلا أنهمـا تختلفـان مـن حيث مهمـة كل منهمـــ فالقرينـة القضائية طريق إيجابى من طرق الإثبات. أما القرينة القانونية فهى إعفاء من الإثبات،

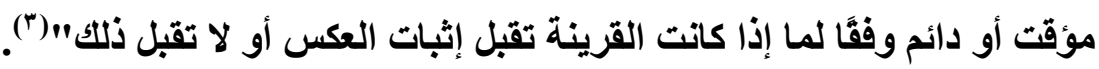

حيث الأساس فى "القرائن القضائية يرجع إلى القاضسى فى ذكائه،، وحدة تفكيره وسـلامة رأيه،،

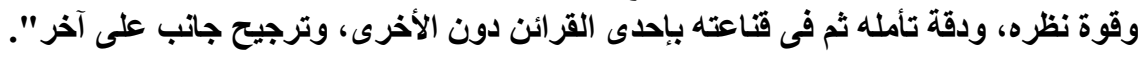

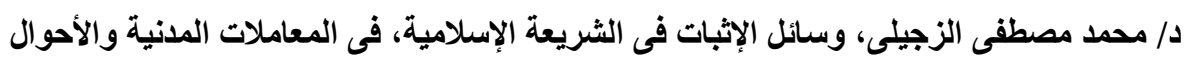

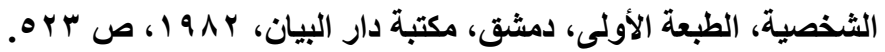

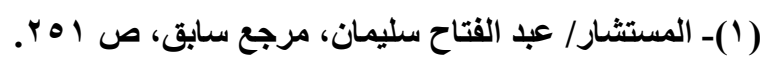

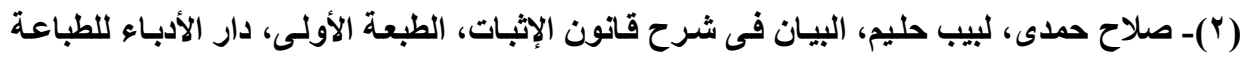

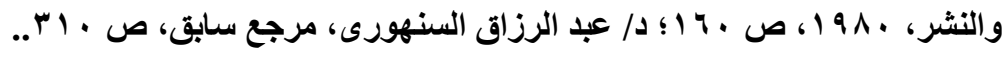

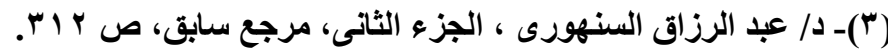


وتؤدى القرائن القضائية التى يستخلصها القاضى الإدارى إلى تيسير عبء

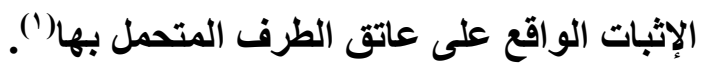

وتظهر أهمية هذه القرائن، وفعاليتها على وجه الخصوص فى الحالات التى التى

يتعذر أو يصعب الحصول فيها سلفًا على أدلة الإثبات أو بالنسبة للوقائع التى ليس من وفن الهن

شأنها الرصد فى الأوراق الإدارية(")

ولما كان الإثبات بالقرائن هو محور بحثنا، سوف نولى لها نوع من الاهتمام

سواء من حيث دورها أو تطبيقاتها فى الأوراق القادمة.

(1)- د/ أحمد كمال الدين موسى، مرجع سابق، ص 11 إ؛.

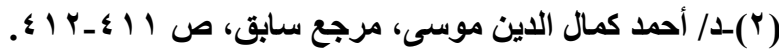




\section{المبحث الثانى}

\section{الإثبات بالقرائن فى القانون الإدارى}

لا شــك يمثل الاثبـات دور كبيـر فـى حـل المنازعـة المعروضــة على القاضسى

الإدارى، وهو ما يستتبع ايضاح من يقع عليه عبء الإثبات فى النظام الإدارى، لمـالـه

من دور كبير فى تنظيم مسألة الحق واسترداده، خاصـة أن طرفى المنازعة الإداريـة ليسوا مثل القضاء المدنى على قدم المساواة فى الامتيـازات والسلطات الممنوحة، ممـا آثار البحث عن ضرورة وجود حل لمثل هذا الوضع الخاص بالمنازعة الإدارية. وسوف نتناول هذا المبحث فى مطلبين على النحو التالى: الامطب الأول: تعريف الإثبات وأهميته فى القانون الإدارى. الاملب الثانى: عبء الإثبات فى القانون الإدارى.

\section{المطابب الأول \\ تعريف الإثبات وأهـيميته فى القانون الإدارى}

الإثبات هو إقامة الاليل أمام القضاء، بالطرق التى حددها القانون، على وجود

واقعة قانونية ترتب آثار ها(').

(1) - د/ عبد الرزاق السنهورى، المرجع السابق، ص • 1 
وبالتالى تحتل قواعد الإثبات أهمية خاصة،لا يستطيع القاضسى أن يستفنى عنها

فيما يتناز عـه الخصوم أمامـه من ادعاءات ومناز عات، فهى فيصل ومعين لـه فى حل النزاع المعروض عليه، بما يحفظ حقوق المتنازعين ويرد الظالم عن ادعاءاته، ويبصر

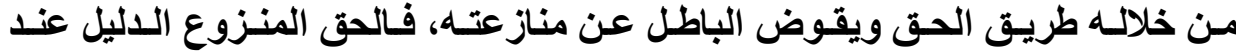
المنازعة قد يصبح هثيمًا تذروه الرياح.

وعلى ذلك كاتت لقواعد الإثبات فى مجـال القانون بشكل خـاص أهمية كبرى إذ من خلاله يمكن لصاحب الحق أن يسترد حقه ويقيم اللاليل عليه، ويجعل للحق كياتًا واضح لا لبس فيه، أمام القانون مما يساعد فى حفظه من الحيف والبهتان.

وهو ما أكدته المذكرة الإيضاحية للمشروع التمهيدى للتقتين المدنى بقولها "إن الحق يتجرد من قيمته ما لم يقم الدليل على الحادث المبدئى له، قانونيًا كان هذا الحادث أو ماديًا، والواقع أن الدليل هو قوام حياة الدق ومعقد النفع فيه"('). ويقول "Planiol" إن "الإثبات يبعث الحياة فى الحق ، ويجعله مفيذًا، وهذا ما يكثف عن الأهمية العلمية للمسائل المتعلقة بالإثبات لمن يريد الحصول على الاعتراف

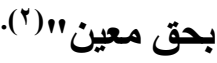

لذلك كاتت نظرية الإثبات من أهم النظريات فى القانون التى تلقى تطبيقا يوميا من المحاكم ولا غنى عنها لما تبرزه من أدلة وبراهين تحسم النزاع لصالح أحد أطراف الف

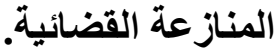

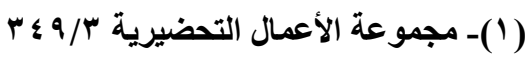
راجع الدكتور/ عبد الرعوف بسيونى، مرجع سابق، ص • ب.

(2) PlaniolRipert et Baulanger: Traitéélémentaire de droit civil 3e édparise 1949 . Paris . T.II p. 825. 
وكسان من شـأن الطبيعة الخاصـة للقـانون الإدارى و الروابط النتى تحكمهـ، أن الإثبات فى القانون الإدارى يختلف عن غيره من القوانين نظرًا لطبيعة الدعوى الإدارية التى تقوم بين طرفين غير متساويين . أحدهما : الإدارة التى تتمتع بامتيازات تجطها فى مركز أقوى من الفرد .

وثانيهها : الفرد الضعيف الأى يتعامل مع الإدارة ويلخل فى علاقات معها' ('). ورغبة من القضاء الإدارى فى تحقيق العدالة فى ظل عدم التوازن بين طرفى

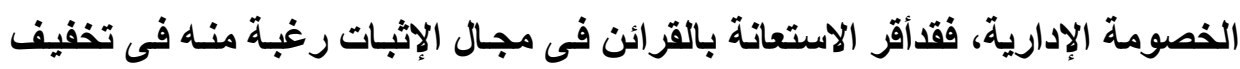

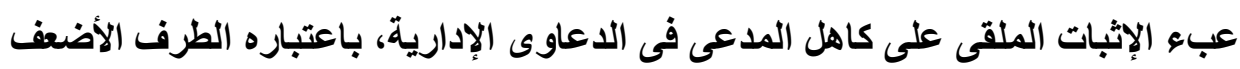

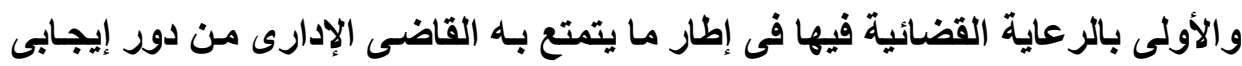

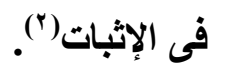

وتقف القرائن القضائية فى مقدمة طرق الإثبات أمسام القضاء الإدارى، فعندما

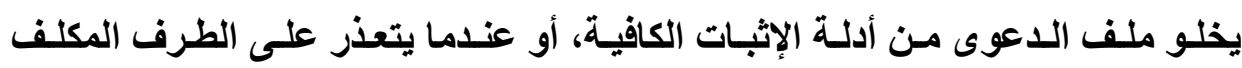

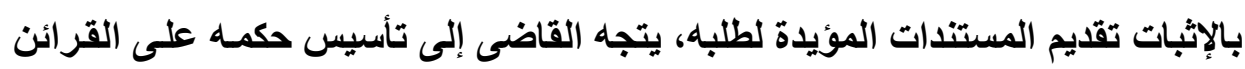
المستقاه من الإمارات والثواهد والإمارات التى تتبئ عنها أوراق الملف والتى تشكل

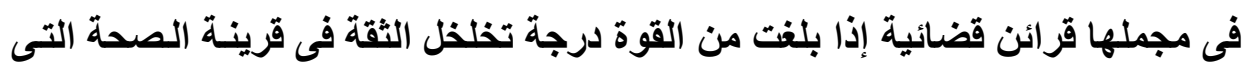

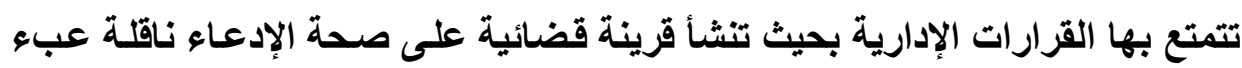
الإثبات ما يخالف ذلك إلى الإدارة(").

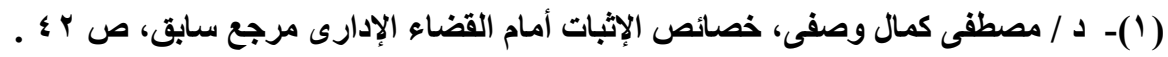

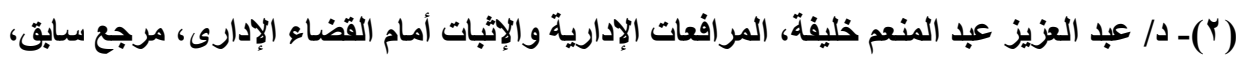
ص r

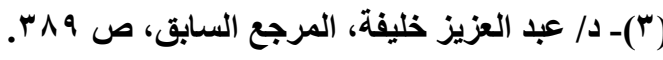

V مجلتّ البحوث القانونيت والإقتصاديت 


\section{المطلب الثانى \\ عبs الإثبات فى القانون الإدارى}

كان من شأن امتيازات الإدارة فى مواجهة الأفراد، حيث يبرز التفاوت الواضح

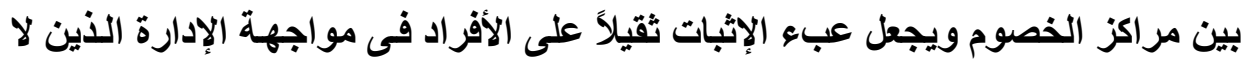
يستحوذون على ذات امتيازات ووسائل الإدارة؛ إن انفرد القاضى الإدارى بدور فعال فى الإدي

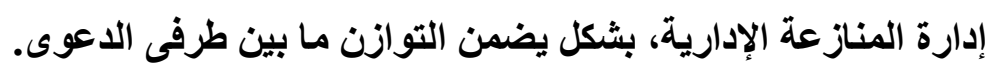
مما جعل القاضى الإدارى يقود الإجراءات الإدارية، ويثكل قد يختلف عما يدار

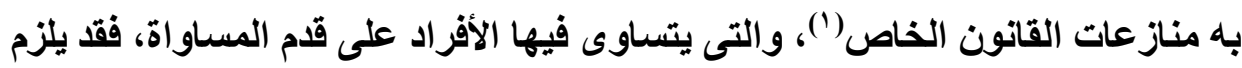

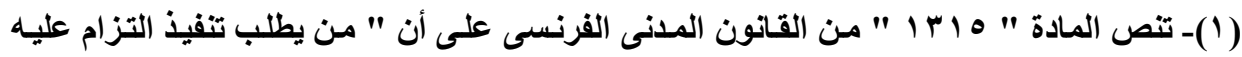

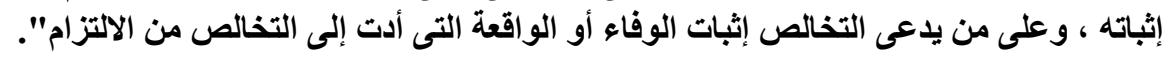

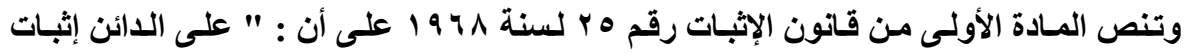

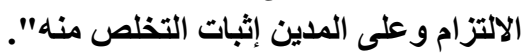
وتتص المادة الأولى من قانون الإجراءات الجنائية على أن : " تختص النيابة العامة بمباثرة

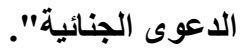

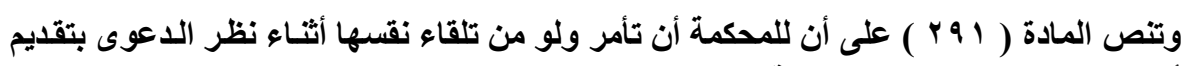
أى دليل تراه لازما لظهور الحقيقة".

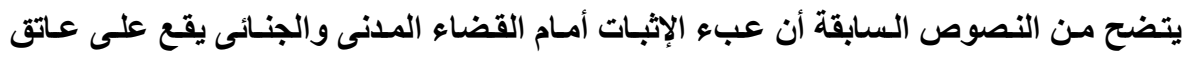

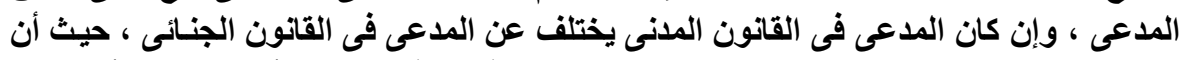

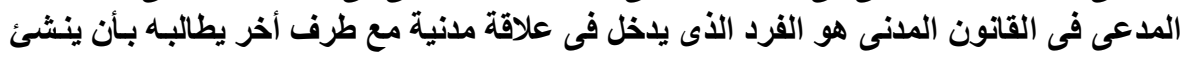

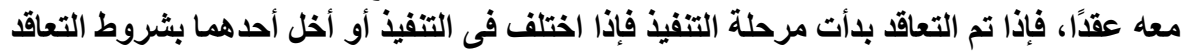
فللطرف الأخر اللجوء إلى القضاء، وله أن يتخذ الإجراءات القضائية أو البوليسية التى يثبت بها لتها

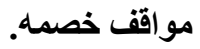

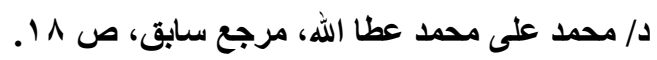

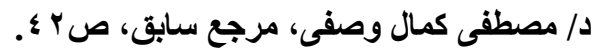

$=$ 
القاضـى الإدارى المـدعى عليـه فى المنازعـة الإداريـة بعبء الإثبـات نـاقلاً العبء مـن

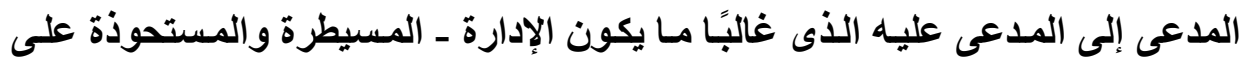
الملفات والمستندات ذات الأثر الحاسم فى الدعوى الإدارية'('). يلجـأ القاضـى الإدارى بالاسـتعانة بجميـع وسـائل الإثبـات أثــــاء نظر الـدعوى الإدارية، فالقاضى الإدارى من تلقاء نفسه أو بناء على طلب الطرف الآخر فى الدعوى

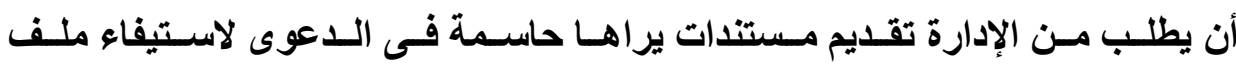
الدعوى() وقد اسـتقرت أحكام القضاء الإدارى على أن نكول الإدارة عن تقديم مـا يطلب منها من أوراق ومستتدات حاسمة فى الدعوى أو تسببها فى فقدها يقيم قرينة

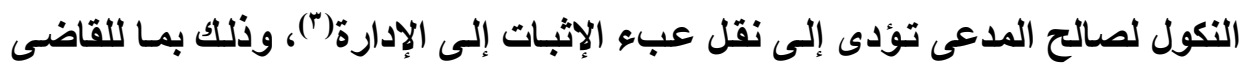
الإدارى من دور إيجابى فى إدارة الدعوى التى ينظرها، وتوزيع أعباء تقديم الأدلة على التى الإدها

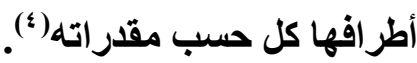

أما المدعى فى القانون الجنائى فهو النيابة العامة التى تمثل الإدعاء حيث يفترض إنى أن المتهم برئ

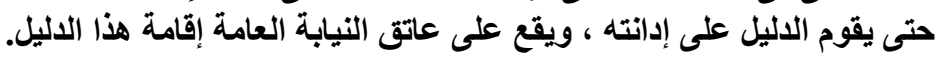

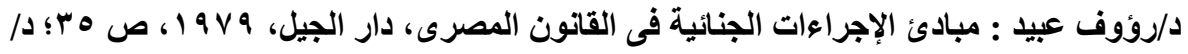

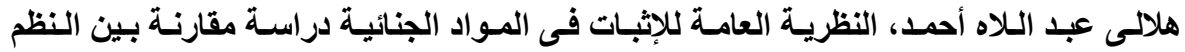

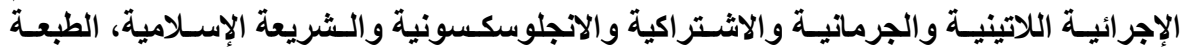

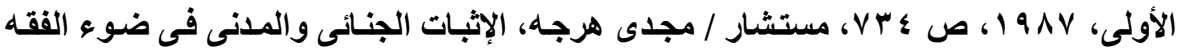

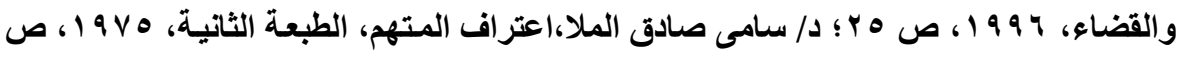
.Ar

(1) -Ch. Debbasch et Recci, contentieux administrative, D., 1985, p. 502.

(Y)

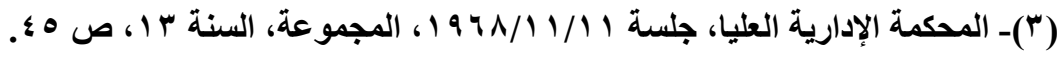

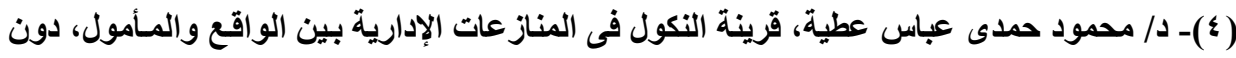

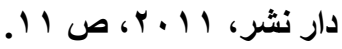


وإعمالاً لمذهب حريـة الإثبات الذى يعتنقه القاضى الإدارى فإنها يتمتع بسلطة

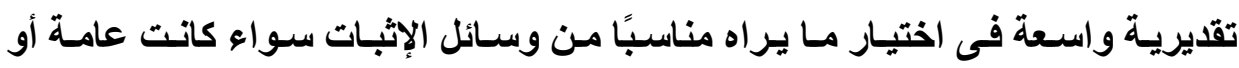

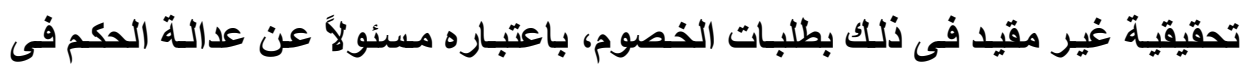

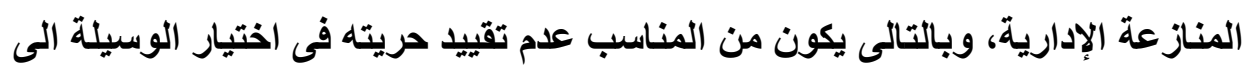
يعتقد بحسه القانونى أنها الأوفق فى التوصل لحقيقة الإدعاء فى الدعوى (')

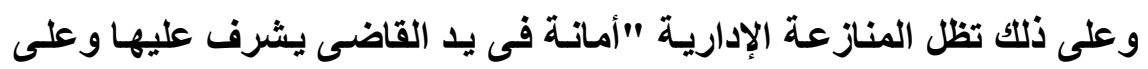

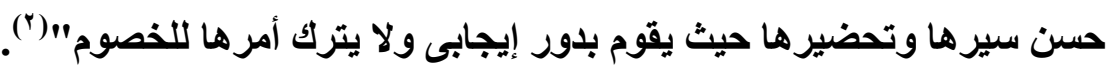
وبذلك يختلف القاضى المدنى عن القاضى الإدارى "فى موقف كل منهمـا من

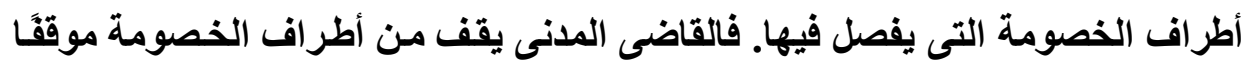

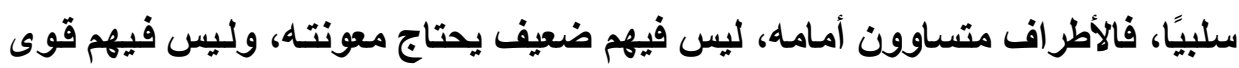

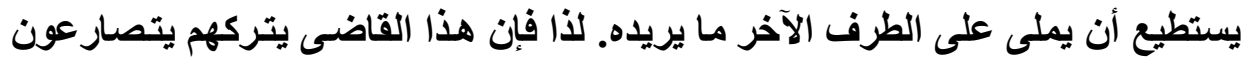

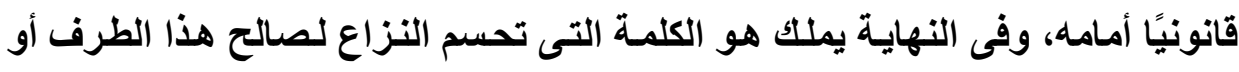

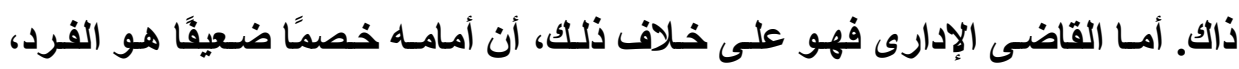

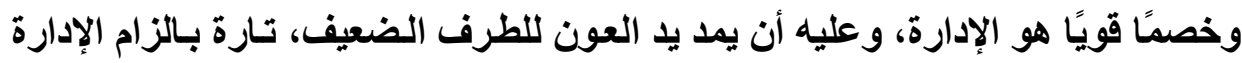

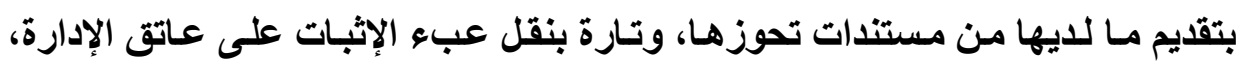
وتارة بافتراض الخطأ فى جانتب الإدارة، إلى غير ذلك من الوسائل التى يحاول بها

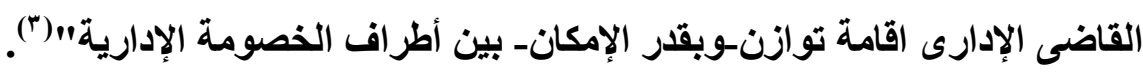

(1)- د/ عبد العزيز عبد المنعم خليفة، المرافعات الإدارية والإثبات أمام القضاء الإدارى، مرجع سابق،

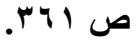

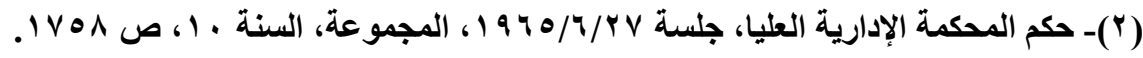

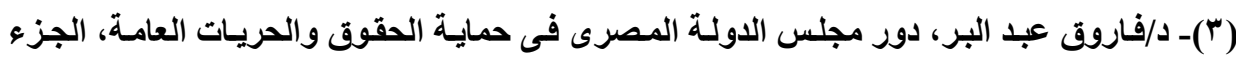

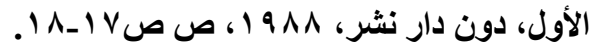




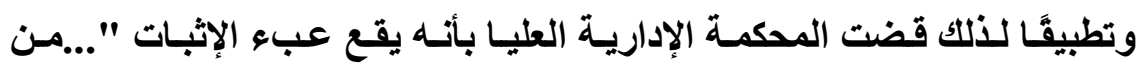

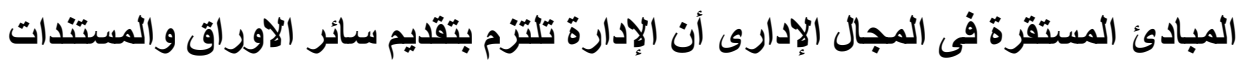

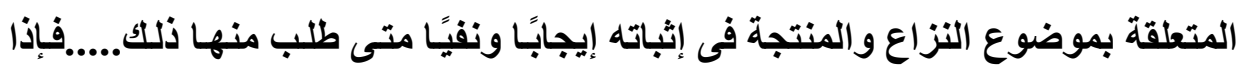

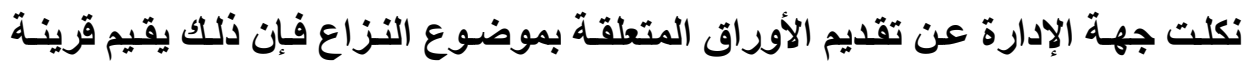
لصالح المدعى تلقى بعبء الإثبات على عاتق الحكومة"(').

\section{المطلب الثالث \\ هبية القرائن فى الإثبات الإدارى}

تختلف حجية القرائن فى الإثبات بحسب كونها قرائن قانونية أم قرائن قضائية

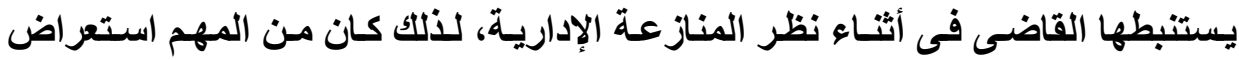
حجية كل نوع من النوعين.

وسوف نتناول هذا المطلب فى فرعين على التحو التالى:

الفرع الأول: حجية القرائن القانونية.

الفرع الثانى: حجية القرائن القضائية

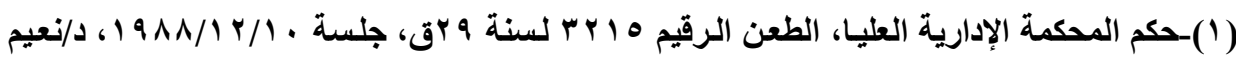

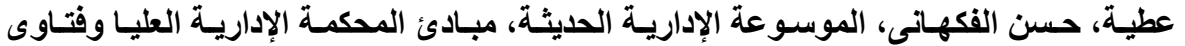

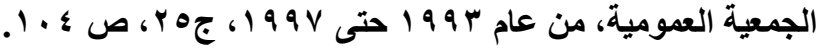

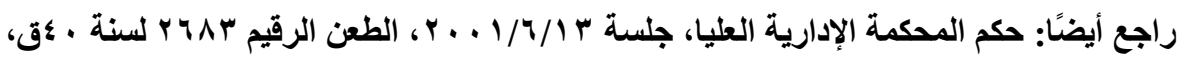

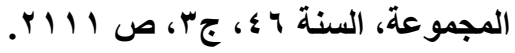

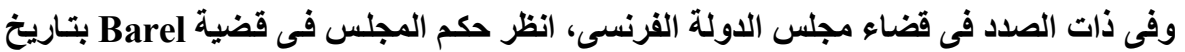

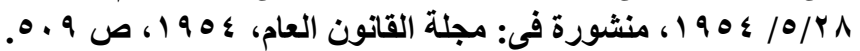

C.E. 28/5/1954, Barel, R.D.P, 1954, p. 509. 


\section{الفرع الأول \\ حبية القرائن القانونية}

تعد القرائن القانونية من الوسـائل التى تعفى من يتمسك بها من الإثبات(')،

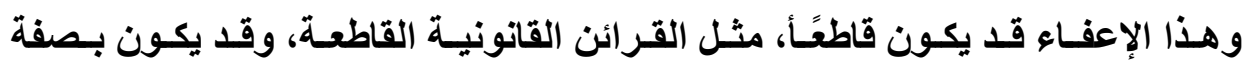
مؤقتة قابل لإثبات العكس، والأصل فى القرائن القانونية أن تكن بسيطة يجوز إثبات عكسها.

وقد وضـع المشرع الفرنسى معيـارًا للتمييز بـين القرينـة القانونيـة القاطعة القية

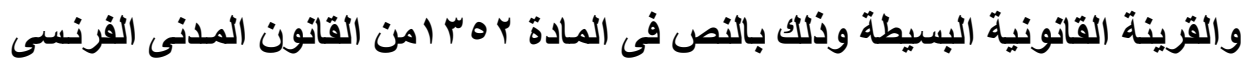
التى جاء نصها كالتالى: "القرينة القانونية تعفى من تقررت لمصلحته عن أى دليل أخر، ولا يجوز إثبات ما ينقض القرينة القانونية إذا كـان القانون يبطل على أساسها بعض التصرفات القانونية أو يجعل الدعوى غير مقبولة هذا ما لم يحفظ القانون الحق

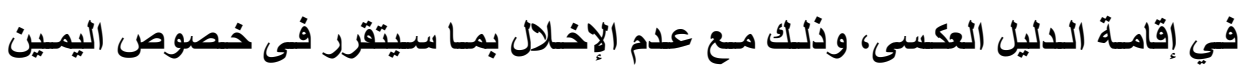

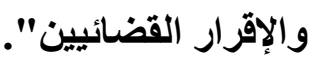

ومقتضى هذا النص أن المشرع بين فى المسادة السابقة الحسالات التى تعد فيها

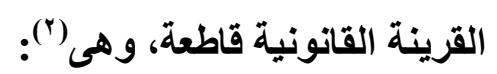

1- إذا كان القانون يرتب على أساسها بطلان بعض التصرفات ، ومن الأمثلة على إنى

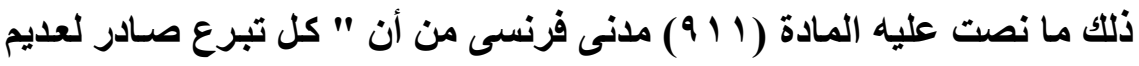

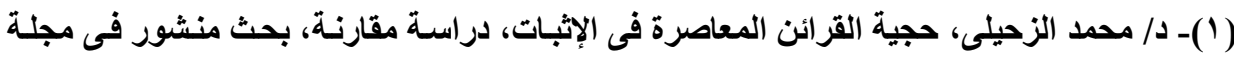

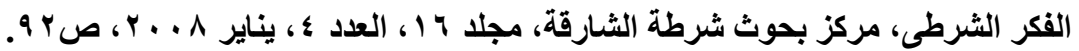

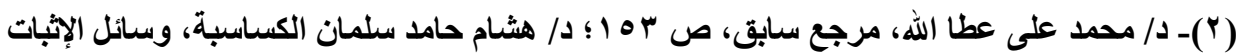

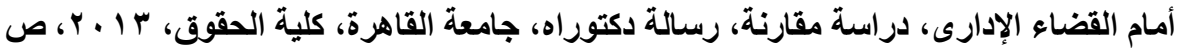


الأهليـة يكون بـاطلا سـواء تحت ستار صورة عقد معاوضـة أو صدر لشخص

مُسخر ، ويعتبر شخصًا مسخرًا لعديم الأهلية أبوه وأمه وفروعه وزوجه "(').

ووفقا لهذا النص تكون الهبة باطلة إذا صدرت لعديم الأهلية مباشرة ، وتأخذ نفس الحكم الهبة التى تصدر لأشخاص معينين بينتهم المـادة السابقة من أقارب عديم الأهلية وذلكك بمقتضى قرينة أقامها المشرع وهى أن الهبة الصادرة لشخص مسخر لعديم الأهلية هى فى حقيقتها تكون لعديم الأهلية وليست لهذا الشخص المسخر وهى قرينة قاطعة لا تقبل إثبات العكس ، ومن ثم لا يجوز لمثل هذا الشخص المسخر الذى الذى صدرت لـه الهبـة أن يثبت أنـه هو المقصود حقيقة بالهبة وأنـه ليس مسخر العديم

r ــ إذا كان القـانون يرتب على أساسـها عدم قبول اللدعوى، من الأمثلة على ذلك قرينـة حجيـة الأمـر المقضى، فحجية الأمـر المقضى تقوم على قرينـة قانونيـة قاطعة لا تقبل إثبات العكس، ومن ثم يترتب على هذه القرينة عدم قبول الدعوى المرفوعة بهذا الشأن ولا يجوز سماعها، ولا يجوز للمحكوم عليه أن يثبت أن الحكم الذى يحتج به عليه غير صحيح. ومــا عـدا هـــه الحسالات التـى نـص عليهـا المـشرع الفرنسـى تكـون القـرائن القانونية بسيطة.

(1) Art 911: annuleensonalinealer les liberalitesfaits par personnesinterposees au profit des incapables l'alinea qui suit dispose " sontreputeespersonnesinterposees les pere et mere les enfants de descendants et l'epoux de la personne incapable . 
وكما يقول الاكتور السنهورى "الأصل أن تكون القرينة القانونية غير قاطعة،

قتقبل إثبات العكس، وهذا شـأن كل دليل ينظمـه القـانون، ولكن هنـاك قرائن أقامها

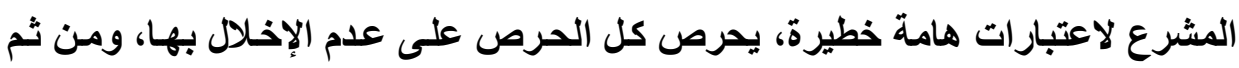

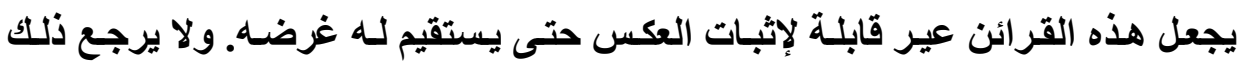

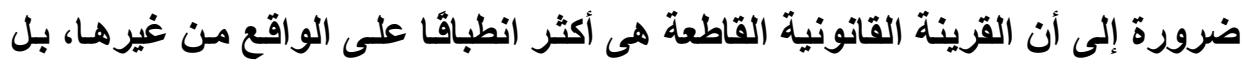

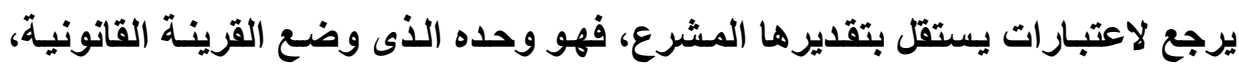
وهو وحده الذى يقدر ما إذا كان يجطلها غير قابلة لإثبات العكس.

ومن ثم كـان واجبًا على المشرع عندما يقيم قرينة قانونية، ويريد أن يحكم

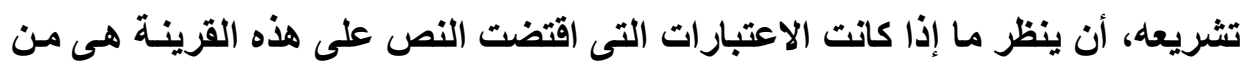

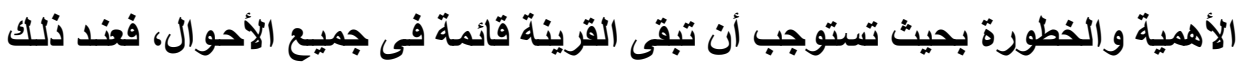

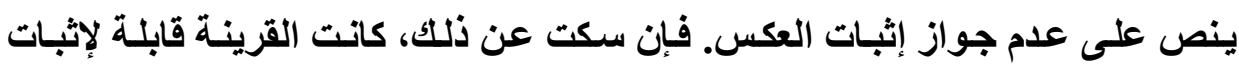

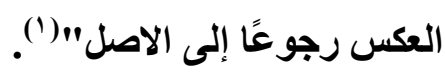

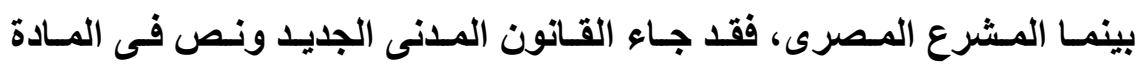

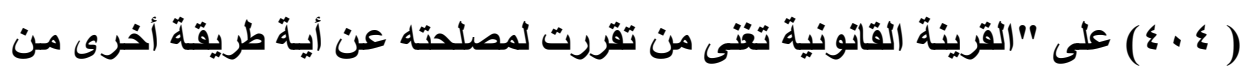

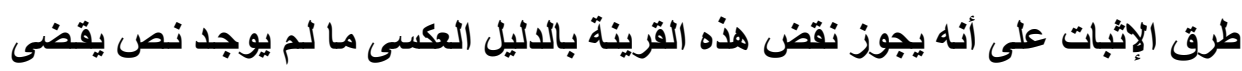
بغير ذلك " وقد حلت محل هذه المادة نص المادة 9 9 من قانون الإثبات المطابقة لها؛

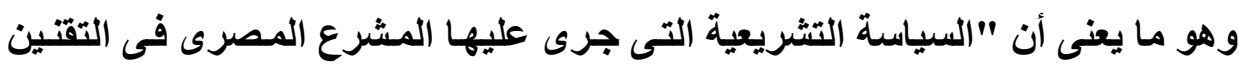

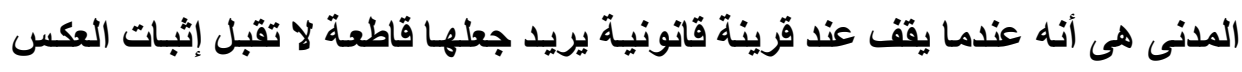
ينص على ذلك، وإن كان النص يأتى بطريق غير مباشر. فعل ذلك فى القرائن القانونية فئة 
على الخطـأ التـى تقـوم عليهـا المسئولية عـن الحيـوان والمسئولية عـن الأثــياء والمسئولية العقدية ومسئولية المستأجر عن الحريق"(').

وإذا كانت القرينة القانونية القاطعة لا تقبل إثبات العكس، فليس معنى ذلك أنها لا تدحض أبدًا، فهى قواعد إثبات، وأيًا كاتت المرتبة التى أرادها المشرع لها فى القطع الته

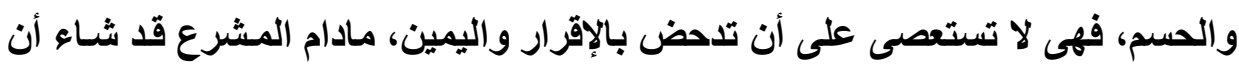

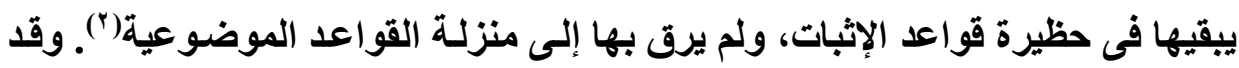

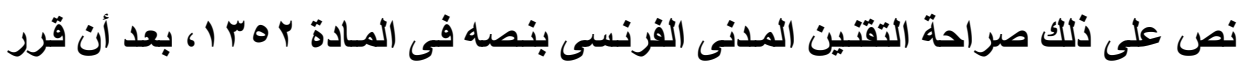
بعدم جواز إثبات ما ينقض القرينة القانونية القاطعة، أثـار إلى مراعاة "عدم الإخلال

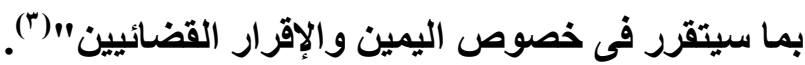

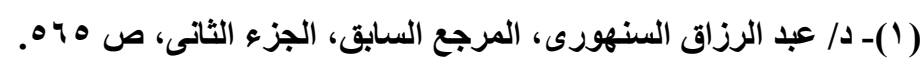

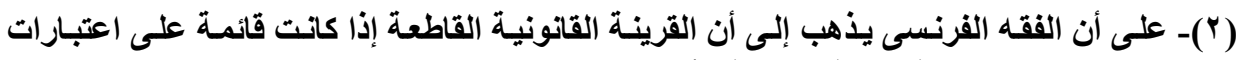

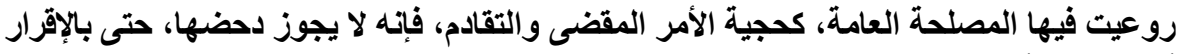

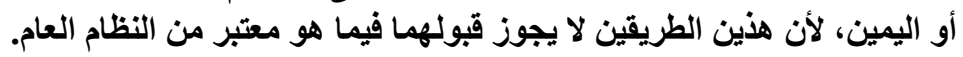

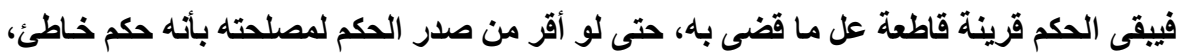

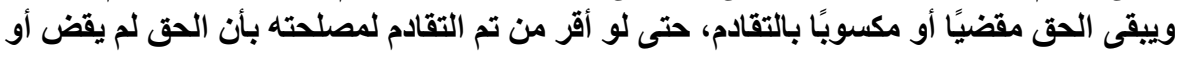

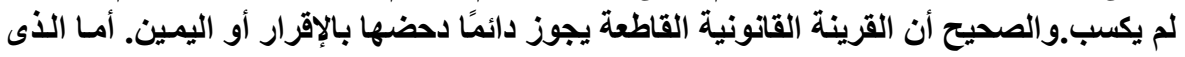

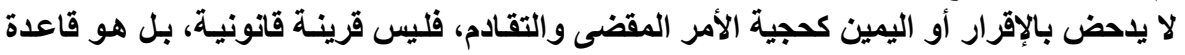

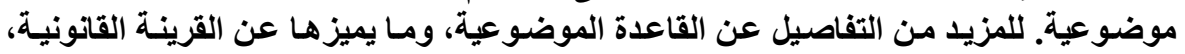

$$
\begin{aligned}
& \text { راجع:المرجع السابق، ص } 979 \text { ه وما بعد ها. } \\
& \text { وبالتالى القرائن القانونية القاطعة نوعان: }
\end{aligned}
$$

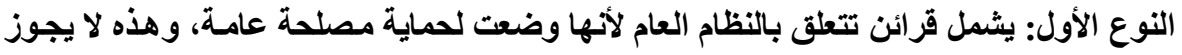

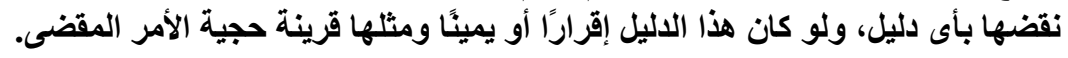

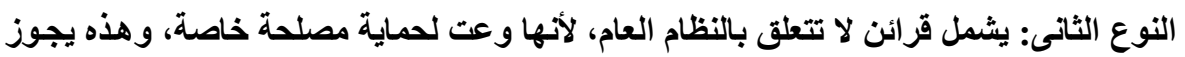
إثبات عكسها.

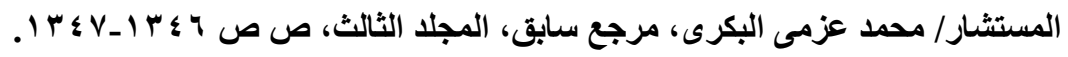

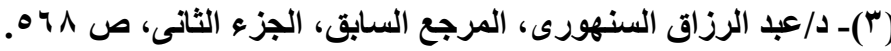


وينبنى على ذلك، أن المسئول مسئولية قائمة على قرينة قانونية قاطعة كما فى المسئولية عن الحيوان وعن الأثياء والمسئولية العقدية ومسئولية المستأجر عن الحريق- لا يستطيع أن يثبت عكس هذه القرينة، ولكنه يستطيع دحضها بإقرار يصدر التهني من خصمه أو بيمين يوجهها إلى هذا الخصم فينكل(').

ومتـى وجد النص على القرينـة القانونيـة وتـوافرت شروطه فى حالـة معينـة وتمسك ذو الشأن بالقرينـة القانونية وجب على القاضى أن يحكم بمقتضاها، أى أن

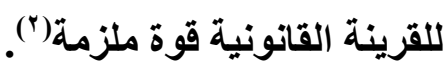
ويتبين مما سلف أن المشرع عندما أنشأ هذه القرينة ويناها على الغالب من الأحوال لم يفته احتمال عدم مطابقتها لكل حالة على حدة، فكان من الطبيعى أن يسمح التها

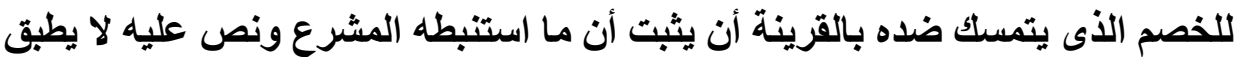
عليه فى الواقع المعروض على هئة المحكمة الخاص بحالته.

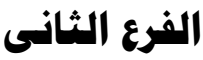

\section{حبية القرائن القضائية}

تلعب القرائن القضائية دورًا بارزًا فى الإثبات سواء كان ذلك فى مجال الدعاوى الإداريـة أو المدنيـة، حيث تكون مـلاذ القاضسى الذى يلجـأ إليها لتسعفه مـع الوسـائل الأخرى فى الإثبات فى الوصول لحقيقة الإدعاء. ونظرًا لما يتمتع به القاضى الإدارى من سلطة تقديرية واسعة فى مجال الإثبات، حيث لم يقيده المشرعكأصل عام- بدليل معين لإثبات واقعة بعينها، فإن دور القرائن الفائن 
القضائية يكون أكثر بروزًا في الاعاوى الإدارية، بحيث تعد من أهم وسائل إثبات تلكت

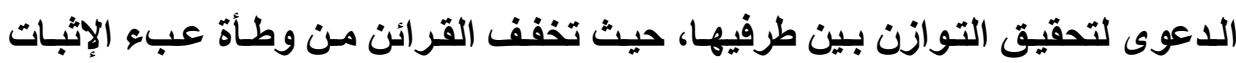

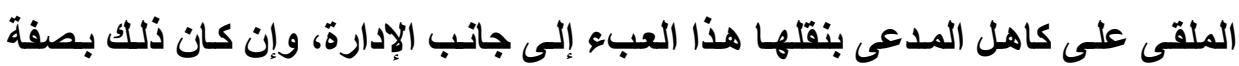
مؤقتة إلا أنه قد يؤدى إلى إنهاء الدعوى لصالح المداعى إذا تقاعست الإدارة أو فشلت التان

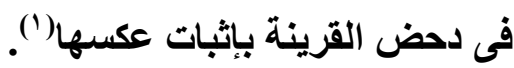

ما يثبت بالقرائن القضائية له حجية متعدية أى أنه يعتبر ثابتًا بالنسبة إلى الكافة

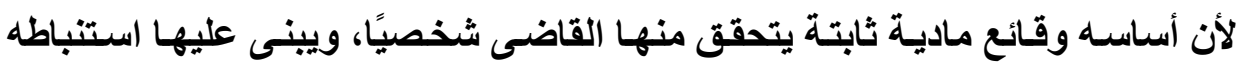

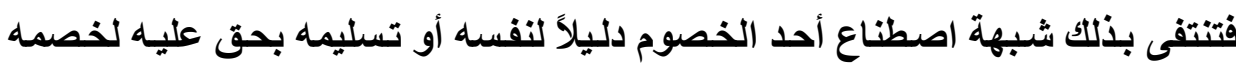
إضرارًاً بالغير (ن)

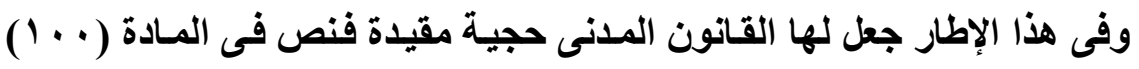

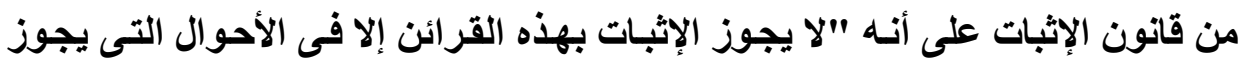

$$
\text { فيها الإثبات بشهادة الثهود". }
$$

وبينت المادة (· ·) المعدلة بالقانون رقم 1 السنة 1999 الهذه الأحوال بنصها

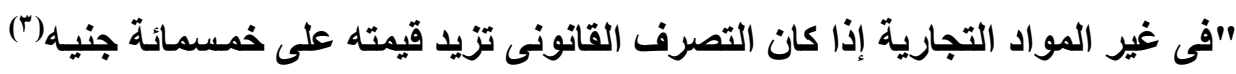

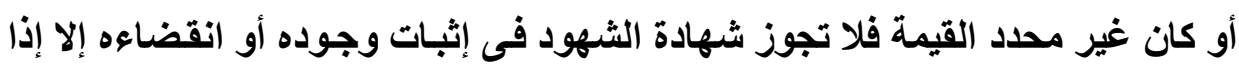

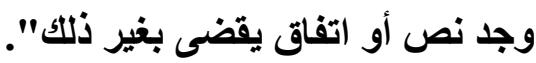

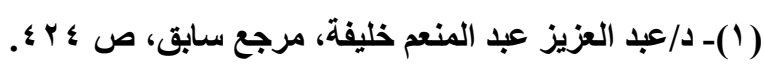

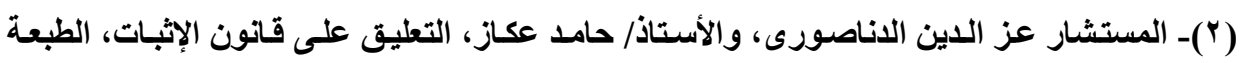

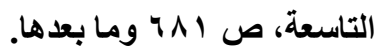

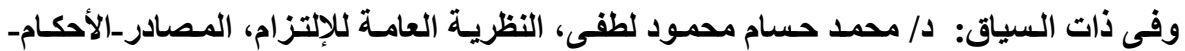

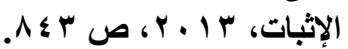

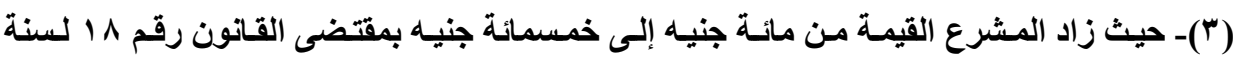

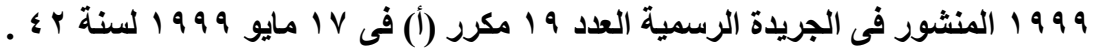


ومقتضى هذا أن القرائن القضائية لا يقبل الإثبـات بهـا أمسام القضاء إذا كـان موضوع الإثبات أمرًا يخالف أو يجاوز مـا يثبت بالكتابة أو كان تصرفا مدنيًا (')تزيد

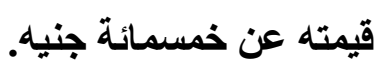
ويستخلص من ذلك أن للبينة والقرائن قوة مطلقة فى الإثبات خارج التصرفات القانونيـة المدنية، فتكون لها هذه القوة المطلقة فى الوقائع الماديـة القانونيـة وفى الإنى التصرفات القانونية التجارية. (†). على إنه من الواجب مراعاة أنه يجوز مـع ذلك "أولاً:الإثبات بالبينة وبالقرائن فيما زاد عن خمسمائة جنيه أو فيما يخالف الكتابة أو يجاوزها إذا كان هناك مبدأ ثبوت التهات

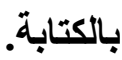

ثانيًا: الإثبات بالبينـة وبـالقرائن فيمـا زاد على خمسمائة جنيه أو فيمـا يخـالف الكتابة أو يجاوزها إذا وجد مانع من الحصول على الكتابة أو من تقديمها بعد الحصول عليها. ونرى من ذلك أن البينة والقرائن، وقد كاتت قوتهما محدودة فى القاعدة العامة، انطلقتا فى الاستثناء، واصبح من الجائز إثبات جميع التصرفات المدنية بهما عند وجود

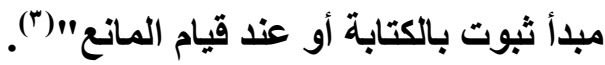

(1) أما التصرفات التجارية فإنه يجوز الإثبات فيها بكافة طرق الإثبات ، والعلة في ذلك مـا يقتضيه

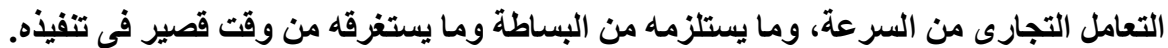

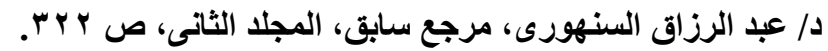

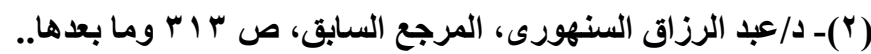

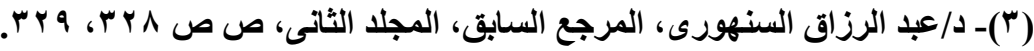


وفى هذا تقول المـكرة الإيضاحية إن الوقـائع الماليـة لا ينبغى أن تذكر بين

الاستثناءات التى ترد على الحكم المتقلم ذكره لأن هذا الحكم لا يسرى بشأنها (1). إن كاتت القرائن القضائية من أدلة الإثبات أمام القضاء العادى؛ فإنها تعتبر فى

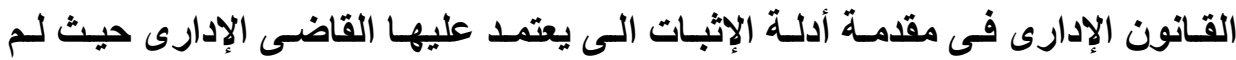

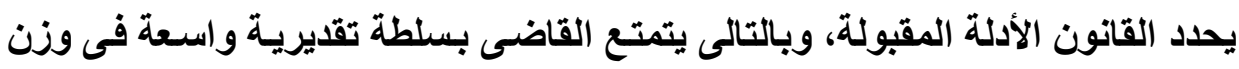

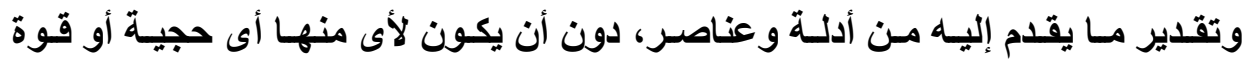

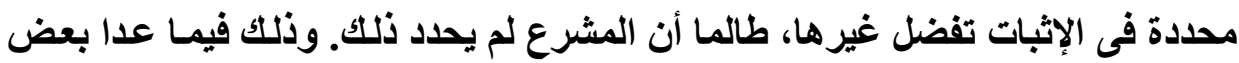

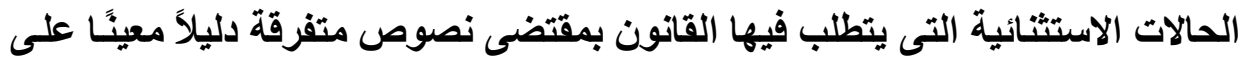

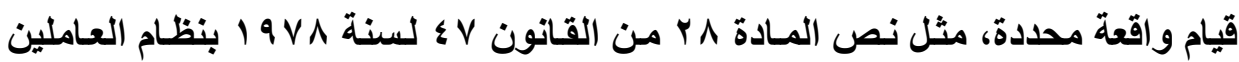

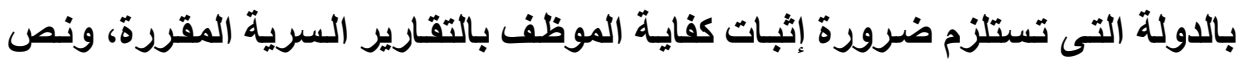
المـادة 74 من ذات القانون التى تتطلب إثبات مرض الموظف بمعرفة الهيئة الطبية

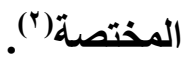
وعلى هذا، تعتبر القرائن القضائية فى مقدمـة طرق الإثبـات أمسام القضاء الإدارى، وتمثل المستندات وغيرها من الأوراق الإداريـة قرائن مكتوبـة قابلـة لإثبات

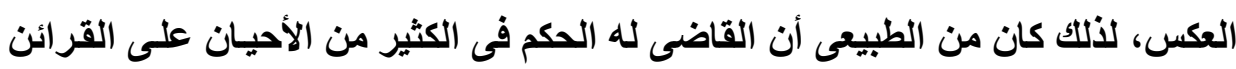

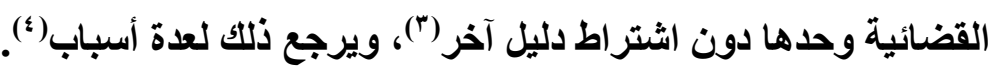

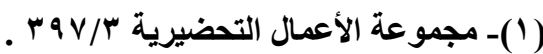

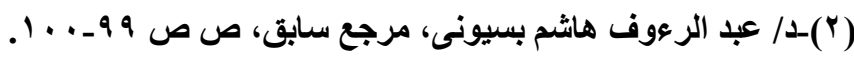

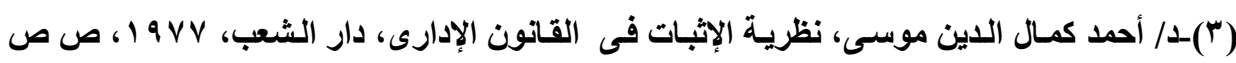
.

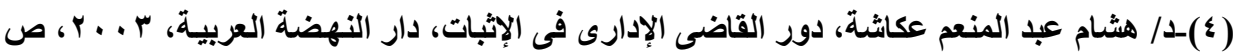

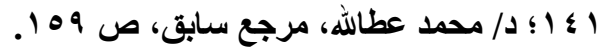


1. اتساع سلطة القاضى الإدارى حيث يتمتع بسلطة تقديرية أثناء نظر الدعوى ولا يتقيد بليل معين. r أن أغلب وقائع القضاء الإدارى هى وقائع مادية. r. أنها تقوم بين طرفين غير متساويين ومن ثم يقتضى الأمر إطلاق يد القاضى في استنباط القرائن التى تعين المدعى فى دعواه وتخفف من عبء الإثبات

$$
\text { الملقى على كاهله. }
$$

وقد اعتد القضاء الإدارى فى كل من فرنسا ومصر بفكرة القرائن القضائية، خاصة مع اتساع المجال فى إطار القانون العام لعمل فكرة القرائن القضائية. و هو ما أكده القضاء الإدارى القرنسى فى أكثر من حكم لله بقولهه "إن سكوت الإدارة عن الرد على ادعـاءات المدعى التى لا تنفيها الأوراق يعتبر إقرارًا ضـنيًا

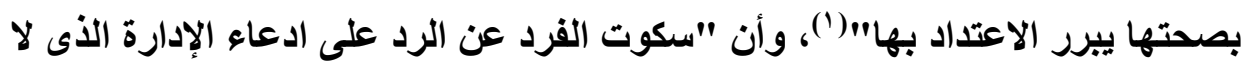

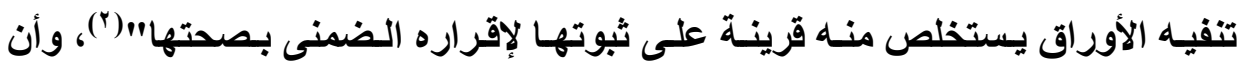

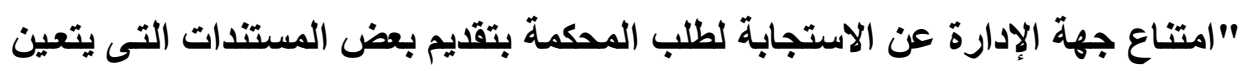
وجودها فى ملف المدعى، يعتبر قرينة على صحة الوقائع التى يدعيها المدعى"("("). ولم يختلف الوضع فى قضاء مجلس الدولة المصرى بشأن الاعتداد بالقرائن

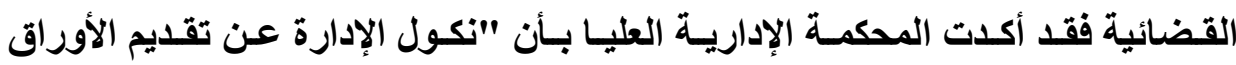

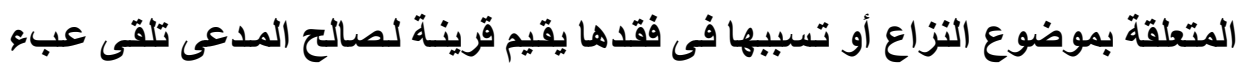

(1) -CE. 23/10/1957, Chailloux, Rec.. p. 548.

(2) - CE. 3/6/1957, Dame Veuve Dang, Rec., p. 994.

(3) - CE. 17/10/1958, Ministre de l'interieur C./Mottard, Rec., P. 490. 
الإثبـات على عـاتق الإدارة، وتجعل المحكمـة فـى حل مـن الأخــ بمــا قدمـه مـن أوراق

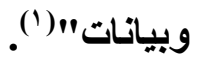

ومن ثم تعد القرائن القضائية حجة فى الإثبات أمسام القضاء الإدارى قولاً واحدًا

سواء كان ذلك فى قضاء الإلغاء أو قضاء التعويض أو قضاء التأديب()؛ ويبرز دورهـا على وجه الخصوص فى الأمور التى يتعذر أو يندر الحصول فيها على أدلة أو بالنسبة للوقائعالتى ليس من شأنها الرصد فى الأوراق الإدارية(")، كالوقائع المادية.

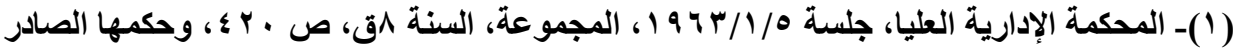

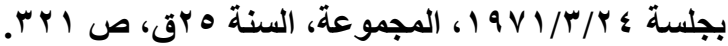
راجع أيضًا:

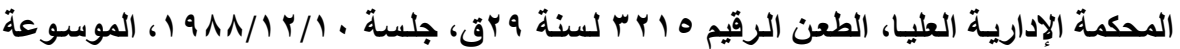

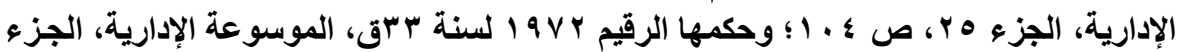

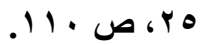

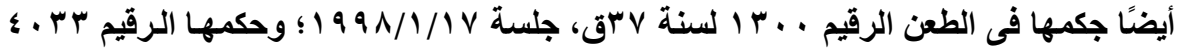

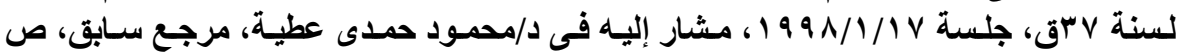
$.11,19$

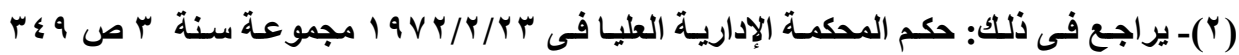

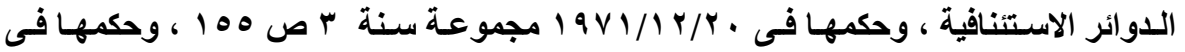

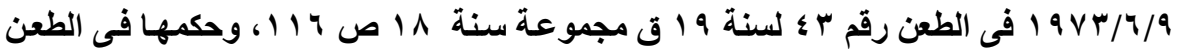

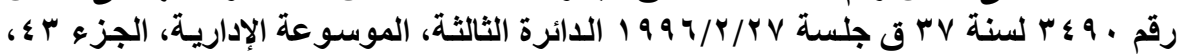

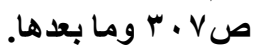

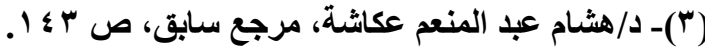




\section{المبحث الثالث \\ تطبيقات للقرائن القضائية فى القضاء الإدارى}

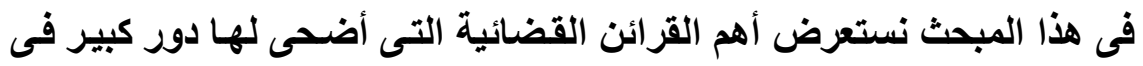

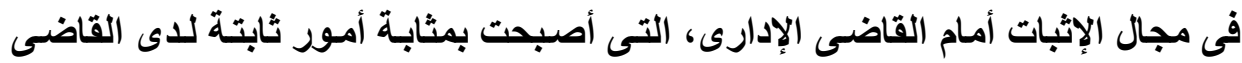

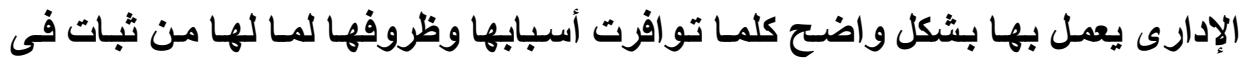

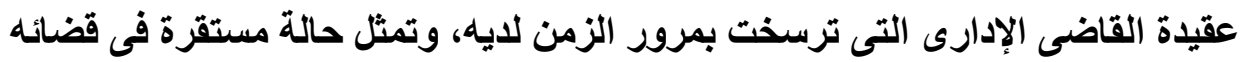

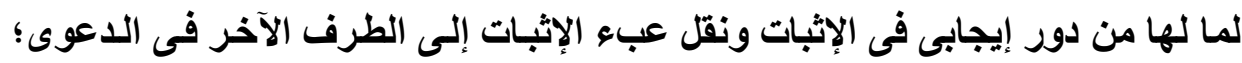

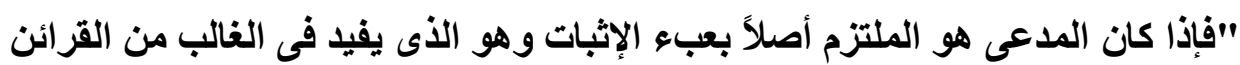

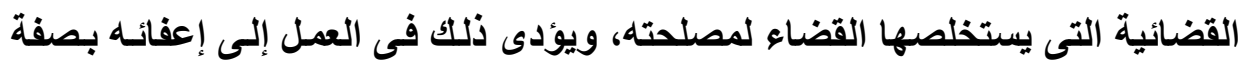

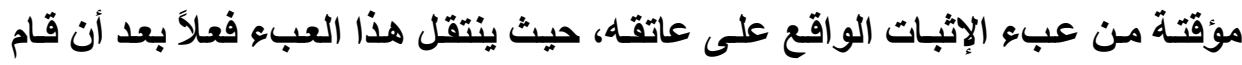

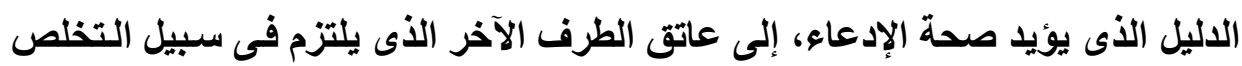

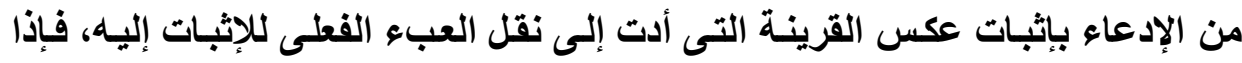

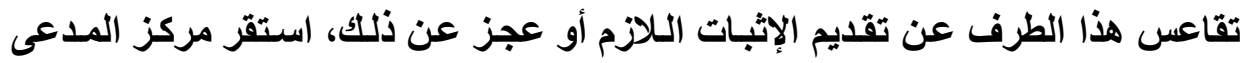

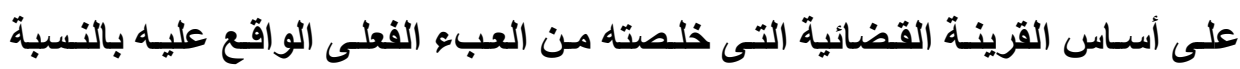

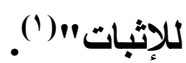

ونستعرض بعض هذه القرائن القضائية التى أصبحت حسالات راسخة أمسام

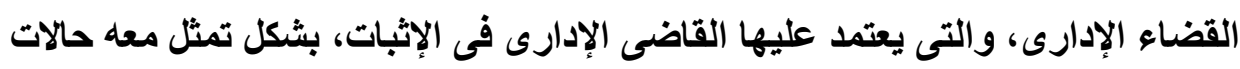

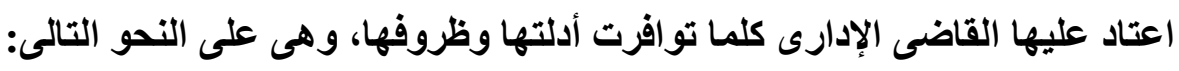
المطلب الأول: قرينة صحة القرار الإدارى المطلب الثانى: قرينة اساءة استعمال السلطة. المطلب الثالث: العلم اليقينى بالقرار الإدارى.

( ) - د/ أحمد كمال الدين موسى، مرجع سابق، ص ب ا ئ. 


\section{المطلب الأول}

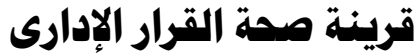

لا شكك يمثل القرار الإدارى عصب ممارسـة الإدارة لنشاطها، ويعد مـن أبرز

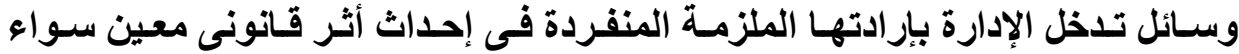

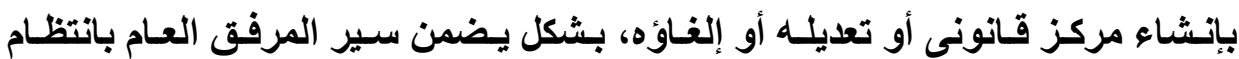
و واضطر اد لتحقيق المنفعة العامة.

وقد عرفت المحكمة الإدارية العليا القرار الإدارى بأنه "إفصاح جهة الإدارة عن

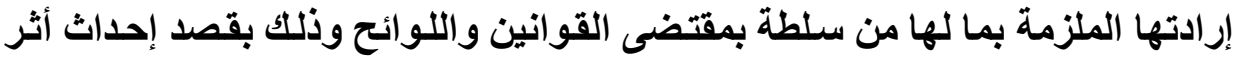

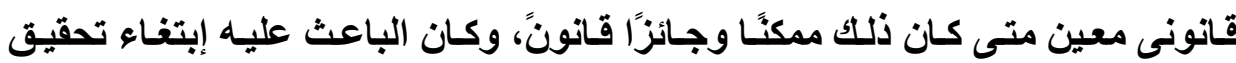

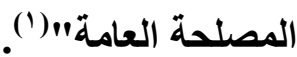

ومن الأمور المستقر عليها فى النظام القضائى سواء المصرى أو الفرنسى، قرينة صحة القرار الإدارى -يطلق البعض عليها قرينة مشروعية القرار الإدارى أو الو الفوني

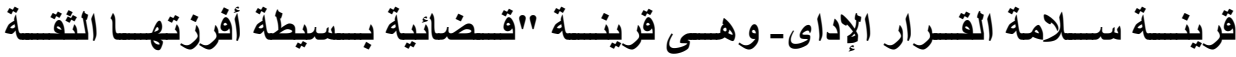

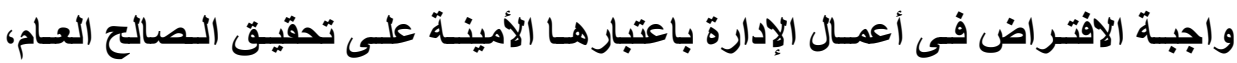

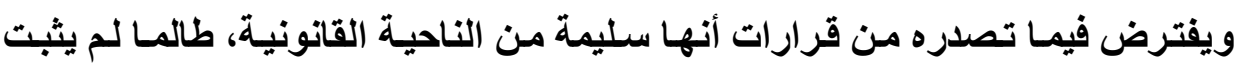

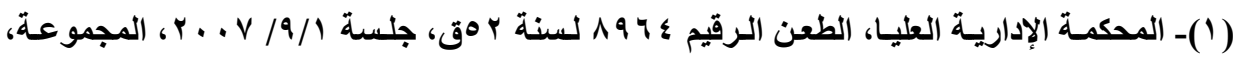

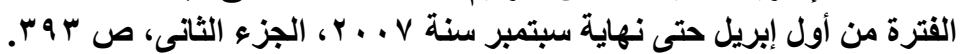

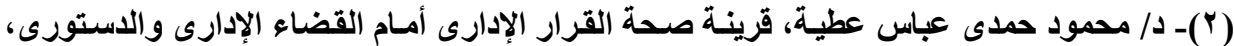

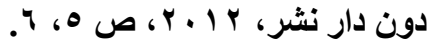


وبذلك يتمتع كل قرار إدارى بقرينة الصحة من حيث صحة أركانـه، ومـا احتواه

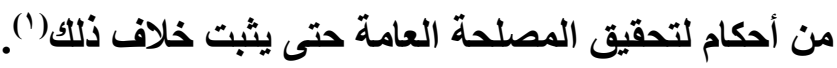

إذ الأصل فى القرار الإدارى أنه صحيح ومطابق لأحكام القـانون، ويبقى نافذ

وفعال ومنتج لآثاره القانونية من تاريخ سريانه حتى تاريخ انقضائهاء")

لذلك يفترض فى القرار الإدارى أن يكون سليمًا من الناحية القانونية بفضل مـا يحيط بـه من ضمـانات خاصـة كحسن اختيار المـوظفين متخذى القرار، ورقابتهم من

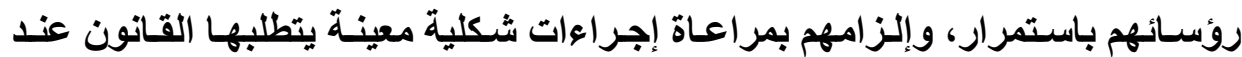
إصدار قراراتهم، واحترام قواعد الاختصاص(").

وقد بررت المحكمـة الإداريـة العليالقرينـة القضائية المتعلقة بصحة القرارات الإدارية بقولها "القرار الإدارى يفتر أن يكون محمولاً على الصحة مـالـم يقم الدليل على عكس ذلك، بفضل ما يحاط به من ضمانات تعين على ذلك كصسن اختيار الموظفين الأين يساهمون فى إعداده وفى إصداره، وتسلط الرقابة الرئاسية عليهم فى ذلك، لأن القرار الإدارى قد يجتاز مراحل تمهيدية قبل أن يصبح نهائيًا"(؛).

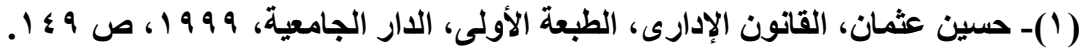

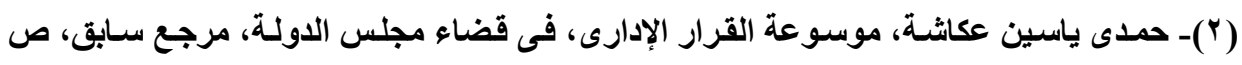

(־)- د/ سليمان الطمـاوى، النظريـة العامـة للقرارات الإداريـة، دراسـة مقارنـة، دار الفكر العربـى،

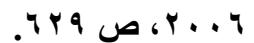

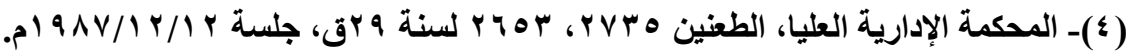

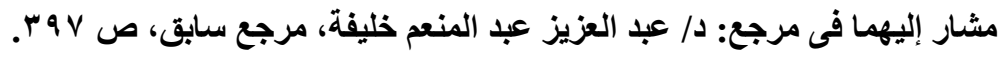

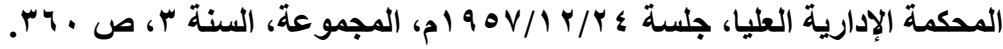


ومن المقرر أن القرار الإداري هو بحسب الأصل قائم على قرينة الصحة، وأن الجهة الإداريـة لا تلزم بتسبيب قراراتها ما دام القانون لا يلزمها بهذا الإدئ التسبيب، إلا أنـه

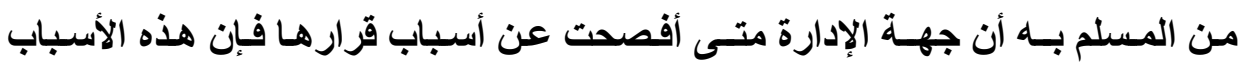

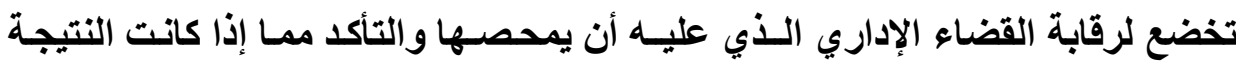
التي انتهى إليها القرار مستمدة من أصول موجودة أو غيـر موجـودة و مـا إذا كانت التهاء

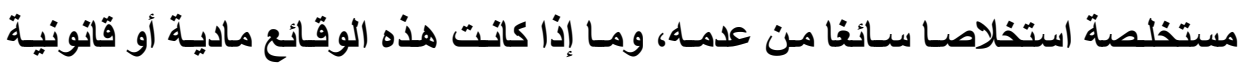
تصلح سبيًا قانونيًا لإصدار القرار( (1). واستنادًا لذلكك، فِان الأصل أن الإدارة غير ملزمسة بتسبيب قرارتها. وفي ذلك

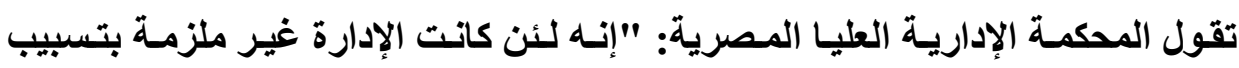

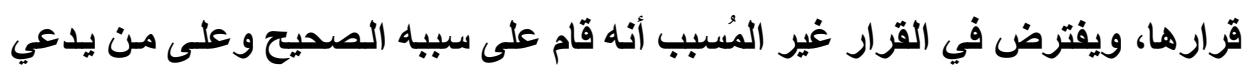

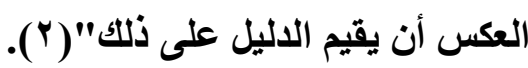
ومن المبادئ المقررة، أن القرار الإداري إذا لم يشتمل على ذكر الأسباب،

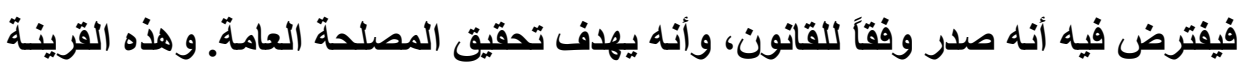

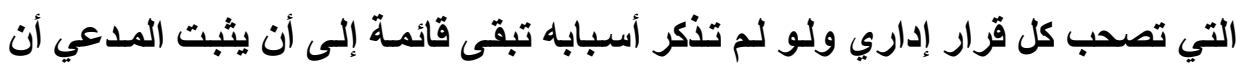

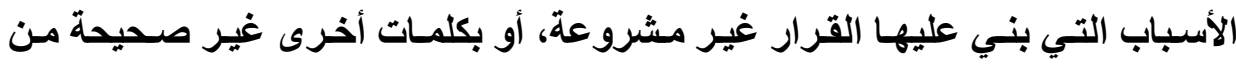


الناحية الو اقعية أو القانونية، ولا تمـت بصلة إلـى المصلحة العامـة، وللمحكمة كامل السلطات في تقدير الدليل الذي يقدّمه المدعي في هذا الصدد (').

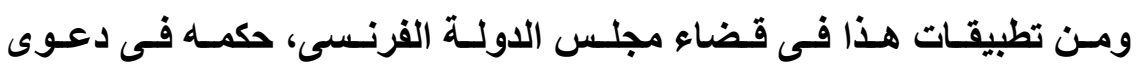
Decremiers قرارها أن المدعى ينتمى إلى المجلس الوطنى القرنسى المنـاهض للحكم فى فرنسا،

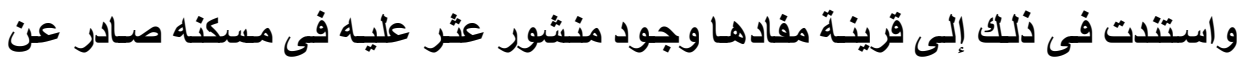
المجلس الوطنى، إلا أن المدعى تمكن من أن يلقى جاتب من الثتك حول إدعاء الإدارة،

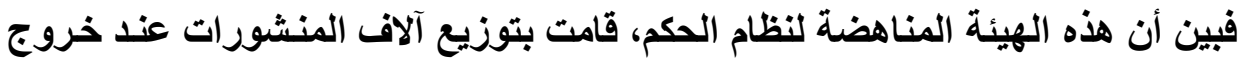

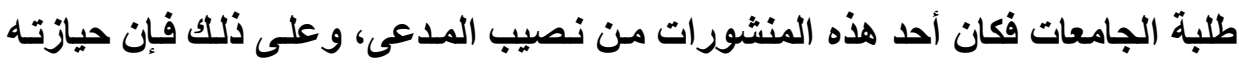

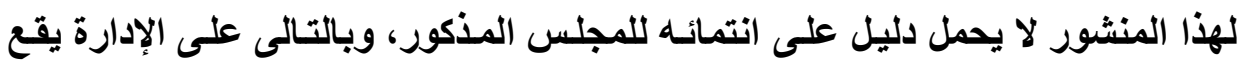
عبء إثبات صحة قرارها فإن هى أخفقت فى هذا تم إلغاء القرار الإدارى لعدم صحة

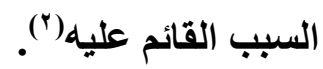

وعلى ذلكت يمكن القول أن قرينة سـلامة القرارات الإداريـة هى افتراض أنها صحيحة استنادًا إلى القاعدة العامة التى تفترض سلامة كل قرار وذلكك بفضل مـا تحاط التها

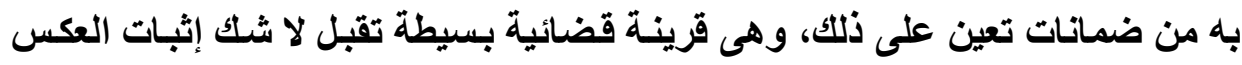
من قبل الخصم المتضرر منها(").

(1)-د. طعيمة الجرف، رقابة القضاء لأعمال الإدارة العامة، قضاء الإلفاء، الطبعة الأولى، دار النهضة

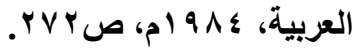

(2)- C.E 30/9/1963, Decremiers, J.C.P., 11 note Debbasch, p. 13577.

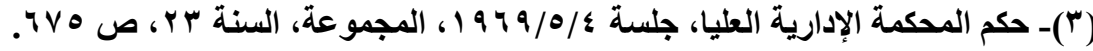


وتبرز أهميـة قرينـة صحة القرار الإدارى بصفة خاصـة فى مجـال الإثبات فى المنازعة الإدارية،؛حيث ينبغى التسليم بأن القرينة على صحة القرارات الإداريـة تميز الغذارة فى تعاملها مع الأفراد، فعى حين أن الفرد العادى يتعين عليه بداية إثبات الحق التقدئ الذى يدعيه فإن دعوى الإلغاء توجـه إلى قرار إدارى يتمتـع بقرينة الصحة، وبعبارة أخرى يقف الفرد فى هذا الخصوص موقف المدعى وتقف الإدارة موقف المدعى عليه حيث يتعين على الفرد إثبات ما ياعيه أو عكس القرينة القاضية بمشروعية القرار فإذاذ نجح فى ذلك فإن القرينة لا تزول بصفة آلية بل ينتقل عبء الإثبات على عاتق الإدارة المدعى عليها، فإذا عجزت عن إثبات صحة قرارهـا أة اتخذت موققَّا سلبيًا غير مقتع، كان قرارها غير صحيح وزالت عنـه قرينـة الصحة. وبالتـالى يقع على من يدعى عدم صحة القرار الإدارى أن يثبت ذلك بوسائل الإثبات القانونية، أى أن عبء الإثبات يقع دومًا على الأفراد، فالإدارة العامة دومًا فى مركز المدعى عليه فيما يتعلق بلدعاوى مدى الإدى الإي صحة القرارات الإدارية ودعوى الغلغاء بشأنها '( ). وبذلك إذا نجح صـاحب الشأن فى زعزعة الثقة المفترضـة فى القرار الإدارى يدرجة يطمئن لها القاضى بأن هذا القرار مخالف للقانون، ينتقل فى هذه الحالة عبء إثبـات صحة القرار ومطابقته للقانون إلى الإدارة، فبان هـ أخفقت فى إثبات ذلتك أو

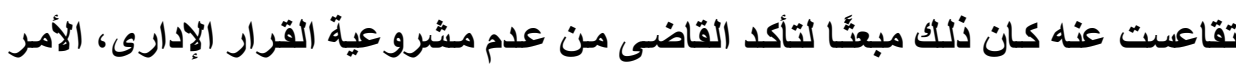
الأى ياعو للقضاء بإلغائه(†).

(1)- د/ محمود حمدى عباس عطية، قرينة صحة القرار الإدارى أمسام القضاء الإدارى والدستورى،

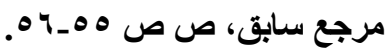

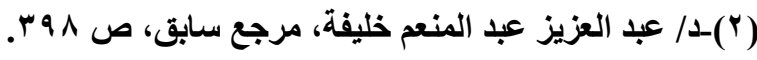


ويمكنتـا القول أن النتائج التى تترتب على قرينة صحة القرارات الإداريـة أن

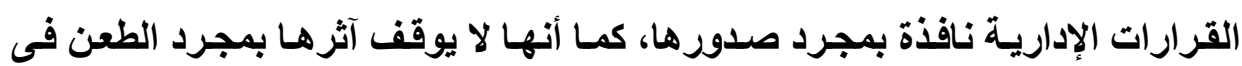

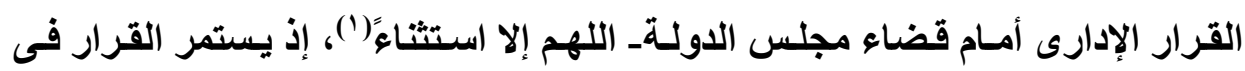
إنتاج آثاره حتى يقضى بعدم مشرو عيتّه.

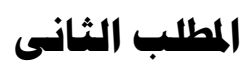 \\ قرينة اساءة استعهمال السلطة}

تمثل اساءة استعمال السلطة(") ـو التى يطلق بعض الفقه عليها نظرية الانحرف

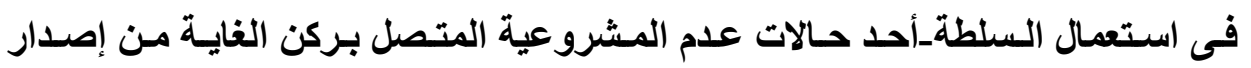

(1) - انظر حكم المحكمة الإدارية العيا الذى أكلدت فيه "أن المشرع حينما خول القضاء الإدارى

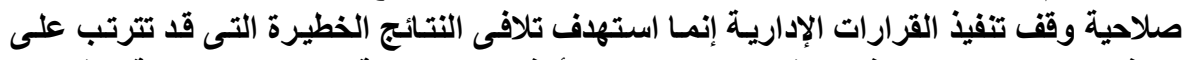

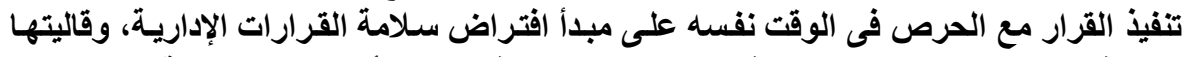

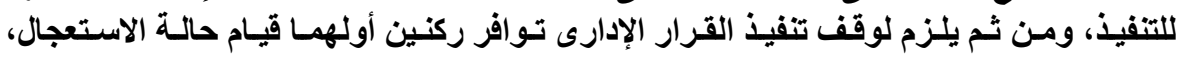

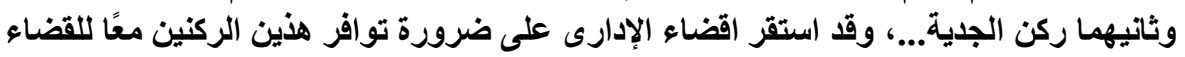

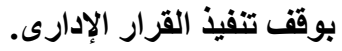

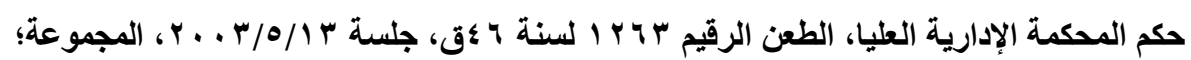

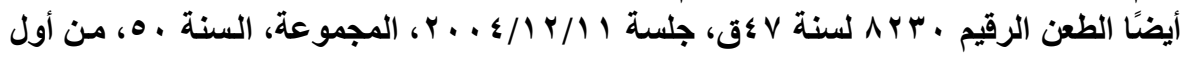

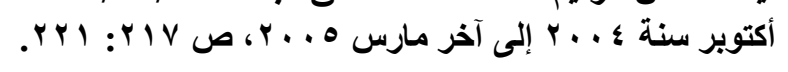

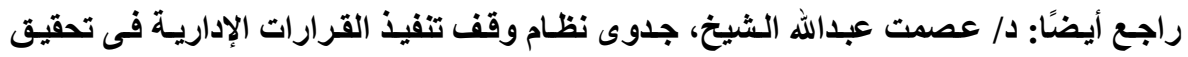

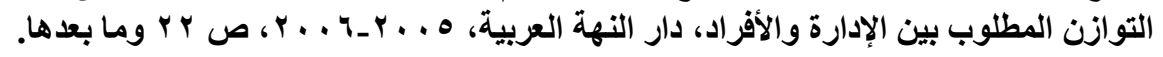

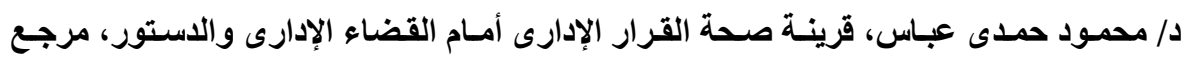

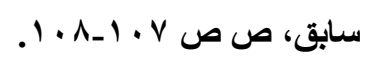

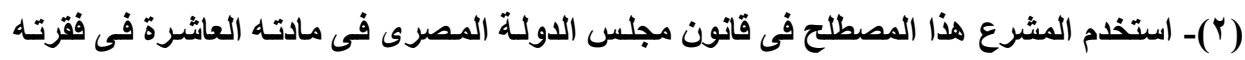

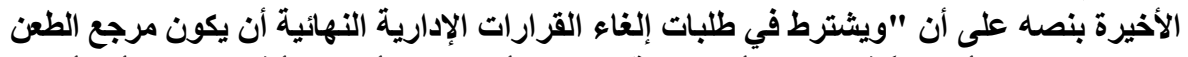

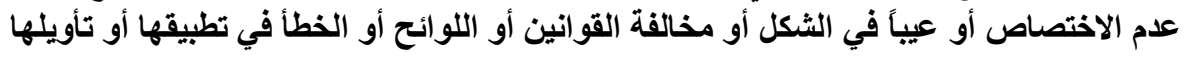

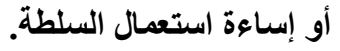
$=$ 
القرار، الذىيبرر الطعن بالإلغاء فى القرار الإدارى، ويقصد به مباشرة رجل الإدارة

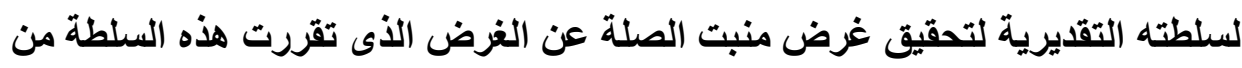

ولما كان عيب اسـاءة استعمال السلطة هو عيب خفى مستتر ويعد من أخطر

العيوب التى تثوب القرار الإدارى أكثرها دقة وحساسية، ولا يحول دون ظهور القرار

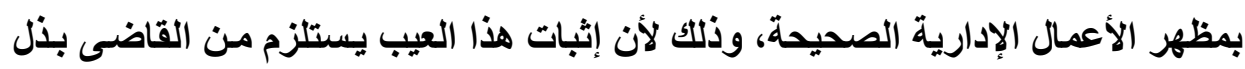

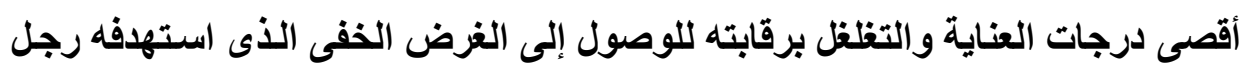
الإدارة من جراء تصرفه، وهو المفترض فيه أنه يسعى إلى تحقيق المصلحة العامة،

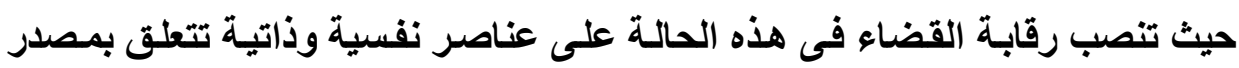

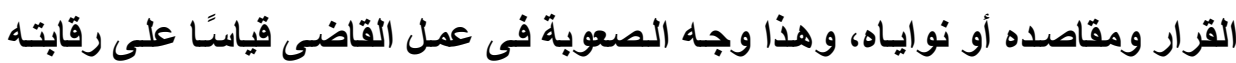

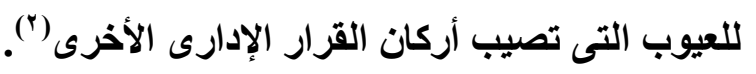

ويعتبر فى حكم القرارات الإدارية رفض السلطات الإدارية أو امتناعها عن اتخاذ قرار كان من الواجب عليها اتخاذه وفقاً للقوانين و اللتوائح.".

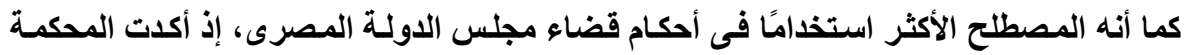

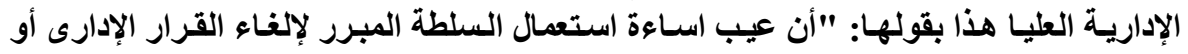

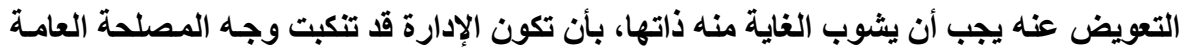

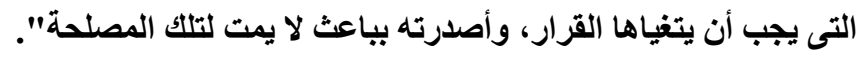

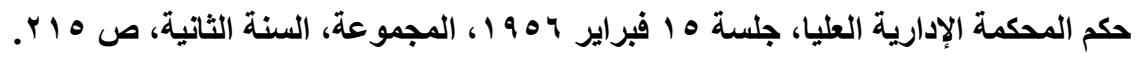

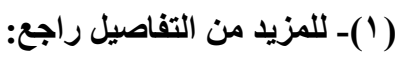

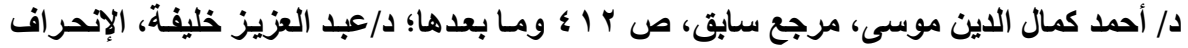

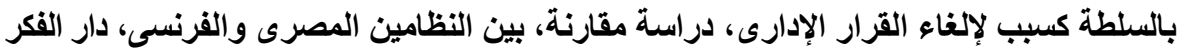

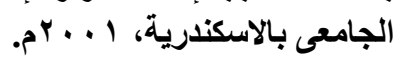

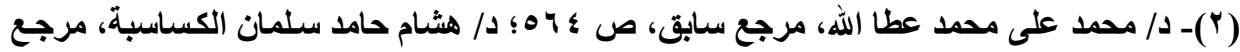

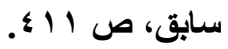


وقد تعددت الألفـاظ فى الفقـه الفرنسى لتعريف اســاءة استعمال السلطة، وأن حملت ذات المعنى فى الأغلب،على التحو التالى:

فقد عرفه الفقيه Vedel بأنه "اسـاءة استخدام السلطة الإداريـة لتحقيق هدف آخر بخلاف تلك التى كاتت ممنوحة بشأنه"(').

وقد عرفـه العميد الفقيه ”Auby“، بأنـه"خل في العمل الإداري الذي يحدث

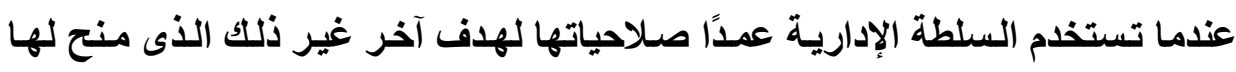

$$
\text { بغرض تحقيقه"(r). }
$$

وهـو ذات مــا ذهب إليـه الفقيـه"Laferrière" بقولـه "هـو اسـتخدام الإدارة

$$
\text { سلطاتها لتحقيق هدف آخر غير الهدف الأى منحت من أجله السلطة"("). }
$$

(1) "détournement de pouvoirconsiste dans le fait pouruneautorité administrative d'user de sespouvoirsenvue d'un but autre que celui pour lequelilsluiontétéconférés".

voir: Vedel (G.), Droit administratif, Thémis. droit Presses Universitaires de France, 6eéd., Paris, 1976, p.602

(2)- "détournement de pouvoirest un vice de l'acteadministratif qui se rencontre lorsqu'uneautorité administrative a utilisévolontairementsespouvoirs dans un but autre que celui pour lequelilsluieteconférés".

J.-M. AUBY et R. DRAGO, Traité de contentieuxadministratif, t. II, 1984, 3eéd., LGDJ, p. 237.

(3) -“...le détournement de pouvoir de ce que l'auteur de l'acte «a usé des pouvoirs qui luiappartenaient pour un objetautre que celui à raison duquelilsluiétaientconférés".

Laferrière (E.), Traité de la jurisdiction administrative et des recourscontentieux, 2eéd., Paris, 1896, p. 548. 
ولم يختلف الوضع للى الفقه المصرى(')، إذ ذهب الدكتور سليمان الطمـاوى إلى أن المقصود بنظرية اساءة استعمال السلطة هو "أن يستعمل رجل الإدارة سلطته التقديرية لتحقيق غرض غير معترف له به"(؟).

وعرف الدكتور طعيمة الجرف اسـاعة استعمال السلطة بأنه "أن تصدر الإدارة قرارًا إداريًا لغير الغرض المقرر له قانونًَا"(").

وذهب الدكتور محمد ليله إلى أن اسـاءة استعمال السلطة هى "(نحراف جهة الإدارة بالسلطة المخولة لها عن هدفها المقرر لها ابتفاء هدف غير مشروع أو غير

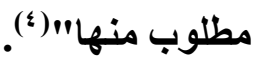

بينمـا عرفها الدكتور يسرى العصار بوجود "بواعث كامنة لدى رجل الإدارة نحو تحقيق هدف غير الهدف الذى حدده له القانون، فإذا لم يكن القانون قد حدد هدقا معينَا، فـإن على رجل الإدارة أن يسعى نحسو تحقيـق الـصالح العـام بـصفة عامسة،

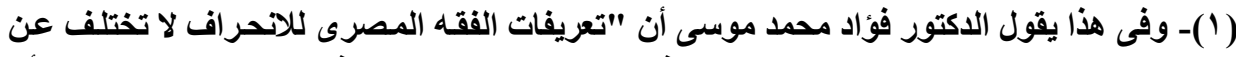

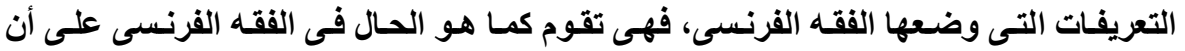

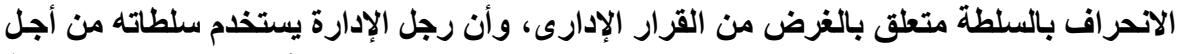

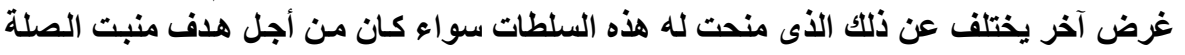

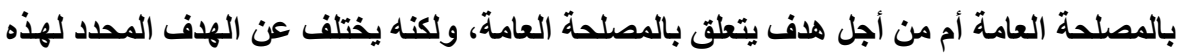
السلطة من قبل المشرع أو ما يطلق عليه الفقه مخالفة قاعدة تخدي تخديص الأهدافـ...".

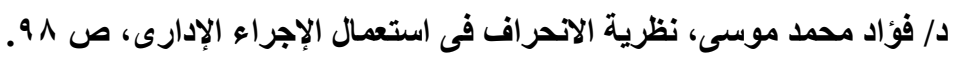

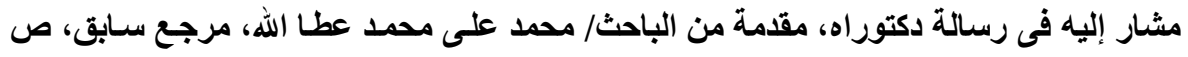
.0TV

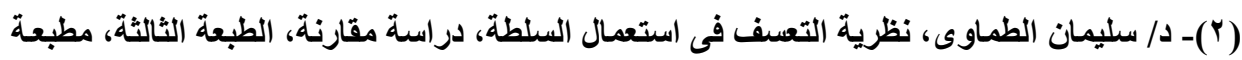

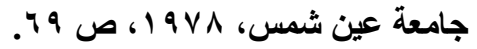

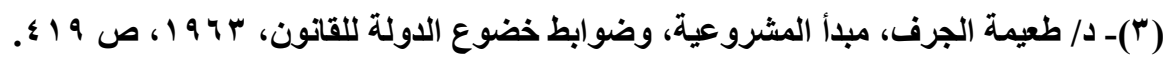

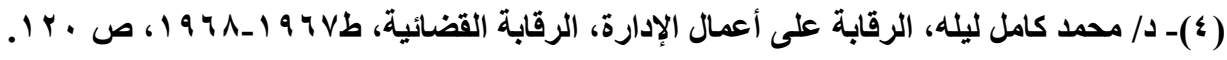


للذلك يجب إقامـة الـليل عليه لأنـه لا يفترض، بـل مـن العيوب القصدية فى السلوك

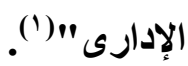

وتعددت أحكام قضاء مجلس الدولة الفرنسى والمصرى فى هذا الشأن وبرزت بثكل جلى فى القرائن التى اعتد فيها القضاء بتوافر قرينـة اسـاءة استعمال السلطة، وسوف نتعرض لأهمها على النحو التالى:

\section{أولاً: قرينة التمييز فى المعاهلة بين المتهاثلين فى المراكز القانونية:}

وتبرز هذه القرينة بشكل واضح عندما لا يكون هنـاك مبرر أو أسـاس مشروع

لهذا التمييزفى المعاملة بين المراكز المتماثلة، فوجود مثل هذا التمييز فى المعاملة بـلا أساس مشروع يمثل قرينة مؤداها توافر اساءة استعمال السلطة فى إصدار القرار، من

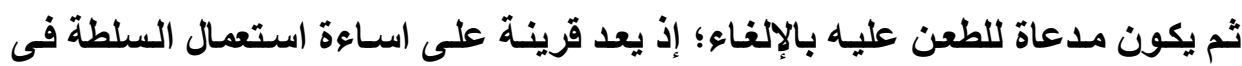
إصدار القرار.

وتطبيقًا لألك، ما قضى به مجلس الدولة الفرنسى من أن عيب اسـاءة استعمال

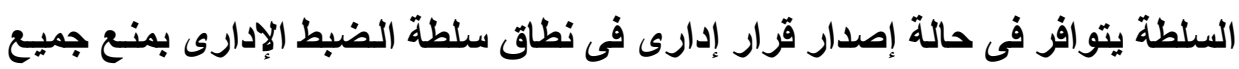
المظاهرات فيما عدا إحداهما؛ إذ كان قد صدر قرار العمدة بمنع المسيرات والمظاهرات

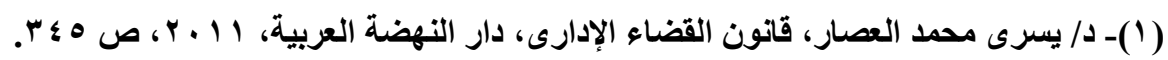

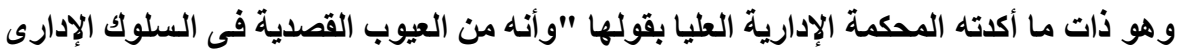

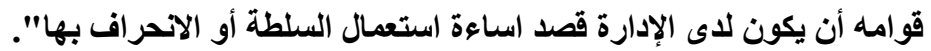

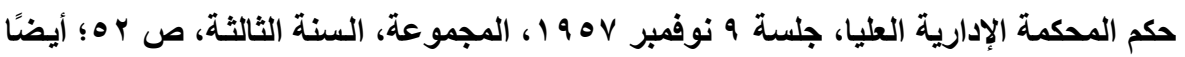

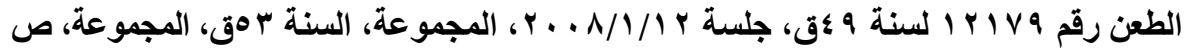


باستثناء واحدة، حيث اعتبرت أن ذلك الاستثناء ينم عن انحراف الإدارة فى استعمال سلطاتها، بتمييزها بين طوائف وانتماعات المتظاهرين (') وفى سياق القضاء الإدارى المصرى، قضت المحكمة الإدارية العليا، بإلغاء قرار جهة الإدارة برفض منح ترخيص بـائع متجول بـائرة الموسكى لبعض الأفراد، رغم استيفائهم لشروط منح الترخيص استنادًا إلى أن واقع الحال بالأسواق لا يسمح بالمزيل

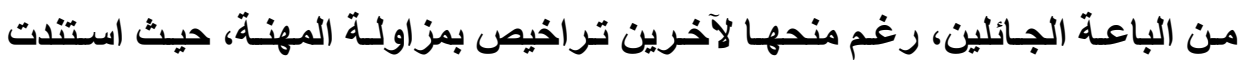
المحكمة الإدارية العليا فى إلغائها للقرار إلى إخلاله بمبدأ المساواة بين أصحاب المراكز

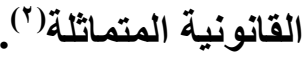

\section{ثانياً: قرينة انعدام الدافع المعقول لإصدار القرار:}

تذور هذه القرينة الدالة على اساءة استعمال السلطة حول صدور القرار الإدارى فى ظروف تثبير إلى غياب المبرر القانونى أو الدافع المقبول لإصدار القرار، وهو مـا يعين المدعى فى إثباتهعلى توافر عيب اساءة استعمال السلطة.

وتطبيقًا لألك قضى مجلس الدولـة الفرنسى بأنـه "نقل الموظف من عمله إلى جهة أخرى لاوجود لها فى الواقع أو منعـه من أداء واجبـه كعددة فى المدينة المنقول منها، يفيد عدم مشروعية القرار على أساس اساءة استعمال السلطة"ا(").

(1)- C.E. 3/8/1927, stade Olympique, Rec., p. 917.

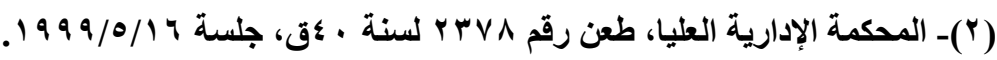

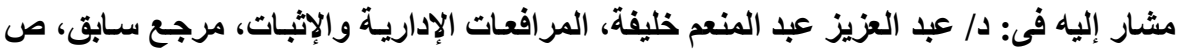
مثار

(3)- C.E. 1911111944,Ozoux, Rec., p. 19;

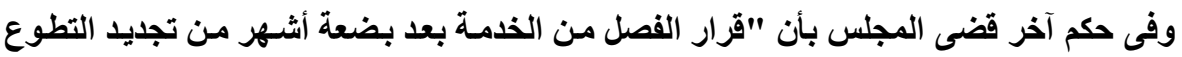

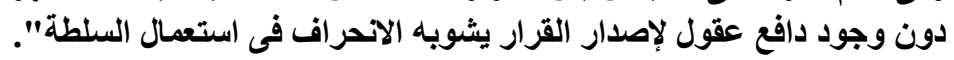

C.E. 271411928, Géorgian, Rec., p. 536. 
وقد قضت المحكمة الإدارية العليا فى مصر، بأنه "إذا كانت الإدارة حرة فى

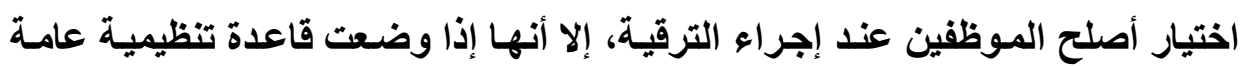

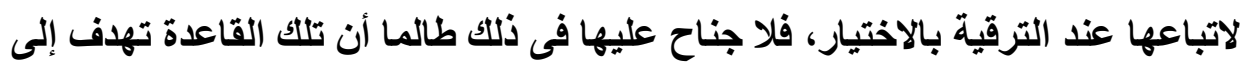

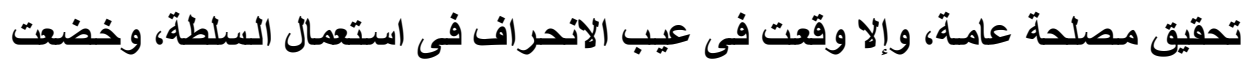
القاعدة نفسها لرقابة مجلس الدولة")(') كمـا قضت بـأن "تلاحق قرارات النقل وصدورها بغير مقتضى من الصالح

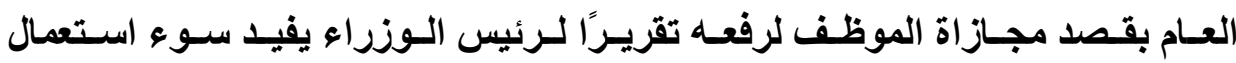

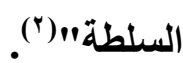

فالقضاء الإدارى يتحرى بواعث العمل وملابساته وأسبابه وفرض رقابته على كل ذلك، للوقوف على الهدف الحقيقى الذى تنثثده الجهة الإدارية فى قرارها، ومها إذا كانت حقًا قد رمت به وجه المصلحة العامة أم تنكبت العبيل وانحرفت به عن الغاية(").

\section{ثالثا: قرينة ظروف وملابسات إصدار القرار الإدارى وتنفيذه:}

يمكن للقاضسى الإدارى أن يستتبط تـوافر اسـاءة استخدام السلطة مـن خـلال

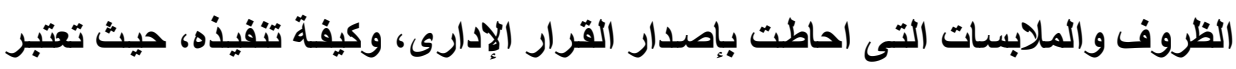

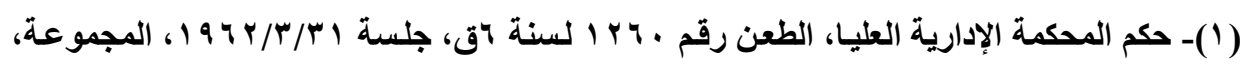

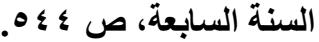

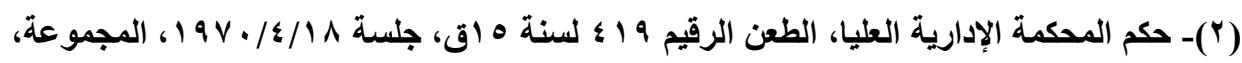

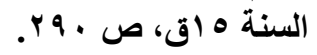

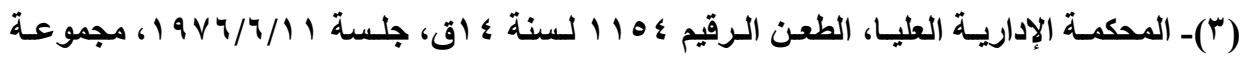

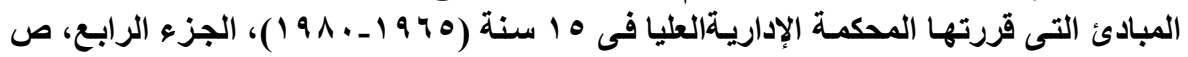
. $\wedge \circ q$ وفى ذات الاتجاه حكمها فى جلسة هـ 1 فبراير 909 19، المجموعة، السنة الثانية، ص 1 1Y. 
الظروف والملابسـات المحيطة بوقائع الدعوى قرينـة على مـدى توافر عيب اسـاءة استعمال السلطة، ومن ثم يمكن الاعتماد عليها فى إلغاء القرار من عدمه(').

وتطبيقًا لألك قضى مجلس الدولة الفرنسى من أن "القرار الصادر برفض منح

ترخيص لإحدى الشركات لتسيير سيارات الأجرة فى المدينة بدعوى عدم الحاجـة إلى هذه السيارات، بـالرغم من أن الثابت أن القرار قد صدر عقب اجتمـاع لنقابـة سـائقى لإنى

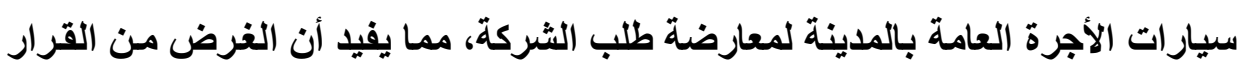

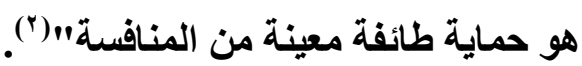

كما ألغى قضاء مجلس الدولـة الفرنسى قرار أصدرته الإدارة ببيع قطعة أرض مملوكة للبلدية لأحد الأفراد بهدف منع تنفيذ حكم قضائى ("). وسـاير قضاء مجلس الدولة المصرى نظيره الفرنسى فى الاعتداد بـالظروف المحيطة بإصدار القرار الإدارى، بقولها "ظروف الحال وملابساته تدل على أن تنفيذه للحكم بعد زوال مصلحة ذوى الشأن في ذلك،، إنمـا تـم بـانحراف السلطة، إذ انتهزت الإدارة الفرصة لتمهيد السبيل لترقية آخرين لم يكونا طرقا فى المنازعة، ولكن قصد من

(1)- près de cet:

"Le Conseil peutaussi se fonder sur les circonstances de fait révélées par l'instructionécrite et d'oùnaissent des présomptions graves, précises et concordantes; mais nous ne pensons pas qu'ilpuisseallerjusqu'àordonner des mesuresd'instruction pour rechercherlui-mêmequellesontétécescirconstances".

Laferrière (E.), Traité de la jurisdiction administrative et des recourscontentieux, op.cit., p.550

(2)-C.E. 10/2/1928, compagnie Pyréneénne de transports par taxis, Rec., p. 204.

(3)- C.E. 16/7/1970, Veuve Huc, Rec., p. 767. 
التنفيذ إبعادهما عن هذا الكادر، فانحراف التنفيذ عن الجادة، وتنكب الطريق مما يصيبه باسـاءة استعمال السلطة، يقطع بذلك أنه كاتـت توجد درجـات إداريـة خاليـة من الممكن

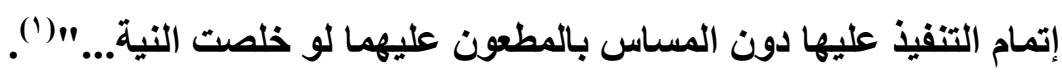
يتبين مما سبق؛ إن قضاء مجلسى الدولة الفرنسى والمصرى، قد استقرا على إمكانية استخلاص عيب اساءة استعمال السلطة من الظروف والملابسات التى احاطت إصدار القرار والكيفية التى نفذ بها، فإذا أصدرت الإدارة قرارها بعيدًا عن باعث تحقيق المصلحة العامة أو الهوف المخصص لها، تحت تأثير ظروف معينة تجعل القرار مشوب لهاب بعيب اساعة استعمال السلطة.

\section{رابعاً: قرينة الغلو أو عدم الملاء همة الظاهرة:}

إن ركـوب مـتن الـشطط فـى القـسوة يـؤدى إلـى إحجـام عمــال الإدارة عـن

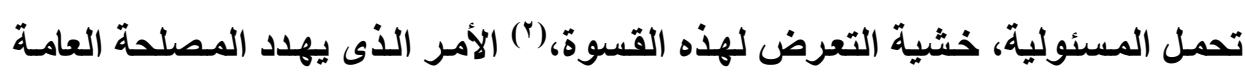
بـلا شك، وينشئ قرينـة على أن القرار الصادر بـالجزاء معيب بالاسـاءة فـى استعمال السلطة.

فالإدارة أن كاتت تثتمع بسلطة تقديريـة فى سبيل إصدار قرارتها تخولها وزن

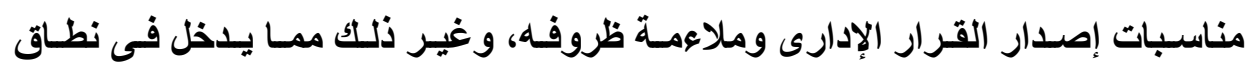

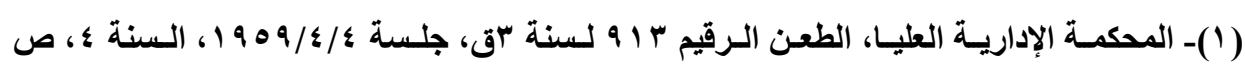
.1.11

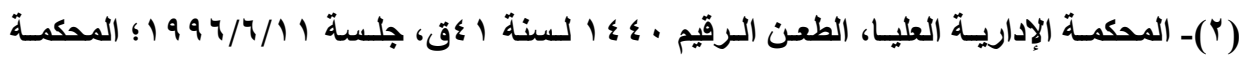

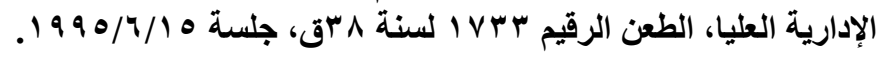

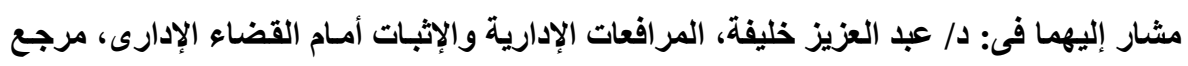

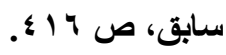


الملاعمة التقديرية التى تملكها الإدارة فى إطار المصلحة العامـة مع الخضوع للرقابة القانونية للقضاء الإدارى (')

فقد ذهب الكثير من أهل الفقه إلى أن الظلو أو عدم التناسب بين الخطأوالجزاء

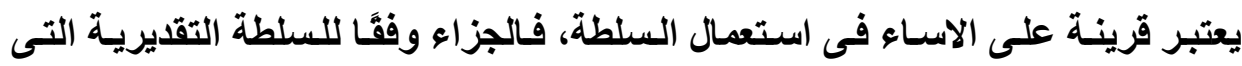

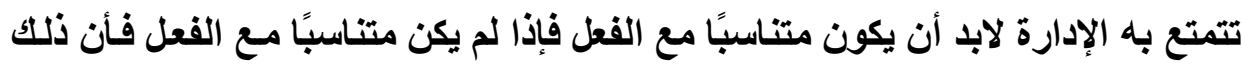

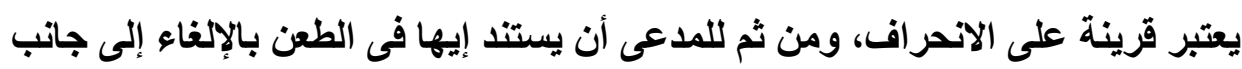

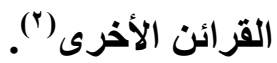

وقد قضى مجلس الدولة الفرنسى بأن "الأصل فى القرارات الإدارية الصادرة

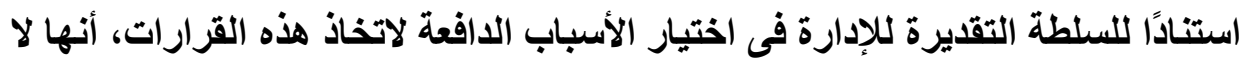

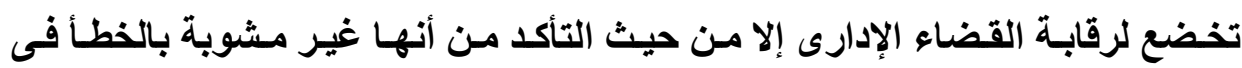
القانون، أو بالخطأ فى الواقع أو بالاساءة فى استعمال السنطة"(").

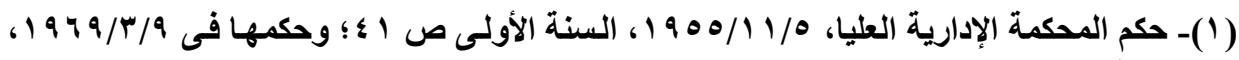

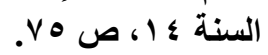

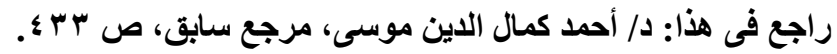

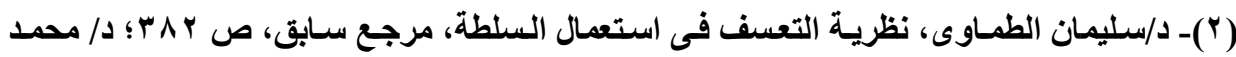

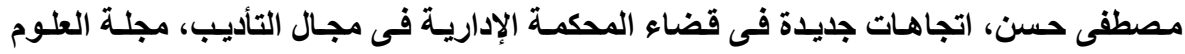

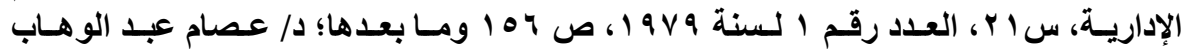

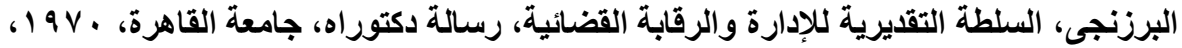

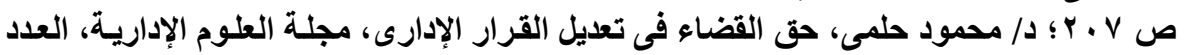

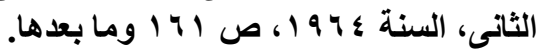

(3)- C.E. 21/12/1960, Serra, D., 1961, p. 421; C.E. 25/4/1980, Institut technique de Dunkerque, Publié au recueilLebon, A.J.D.A., 1980, p.591. 
وفى ذات الاتجـاه قضت المحكمـة الإداريـة العليـا بأنـه "تقدير العقوبـة للـنتب الإدارى الذى ثبت فى حق الموظف هو من سلطة الإدارة، لا رقابة للقضاء فيه عليها إلا

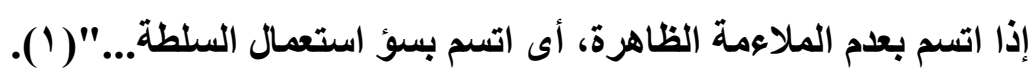
ويعد عدم الملائمسة الظـاهرة بين الذنب المرتكب والجزاء الموقع أحد صـور

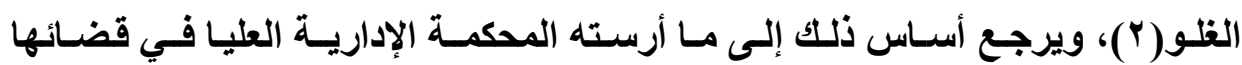

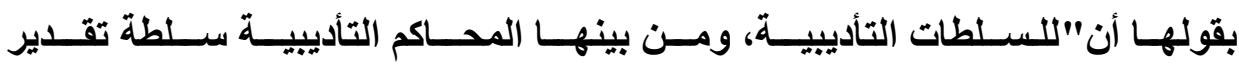

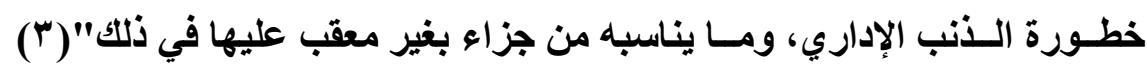
ونخلص من ذلك أن عدم الملاءمة الصارخة أو الغلو يعتبر قرينة قضائية على عيب اساءة استعمال السلطة الإدارية، يدفع لإلغاء القرار الإدارى فى حالة ثبوته.

\section{المطلب الثالث

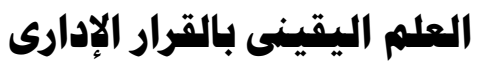

لا شكك أن نثر القرار الإدارى أو إعلاتهـه إلى صـاحب الثـأن يعد قرينة قانونيـة

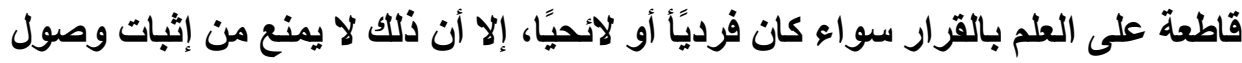

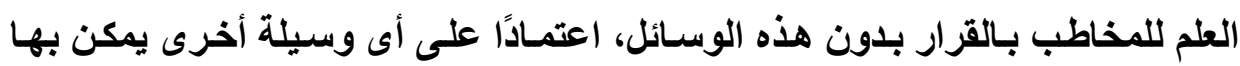

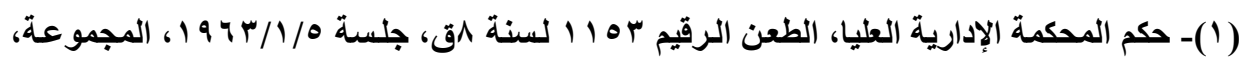

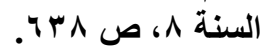

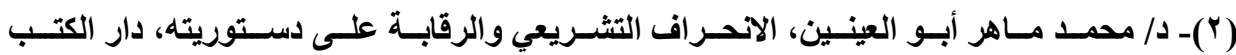

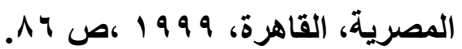

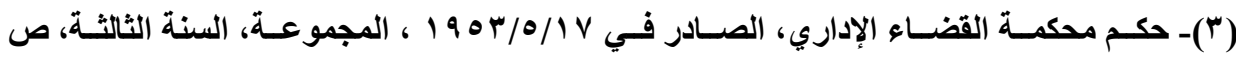




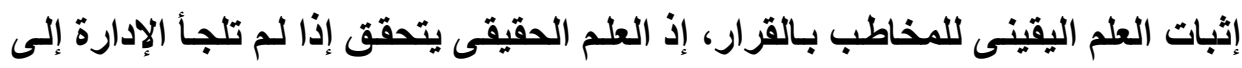

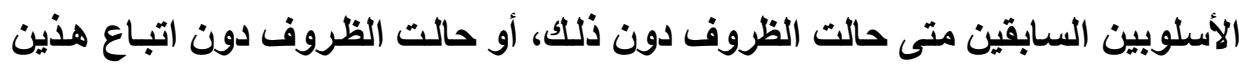

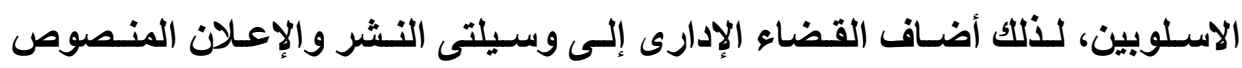
عليهما قانونًا وسيلة أخرى هى العلم اليقينى (').

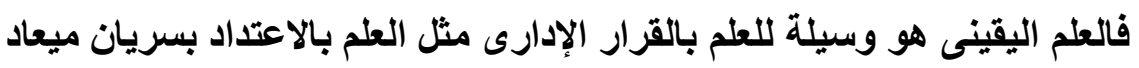

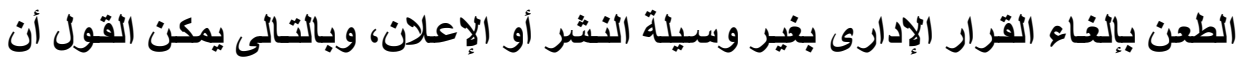

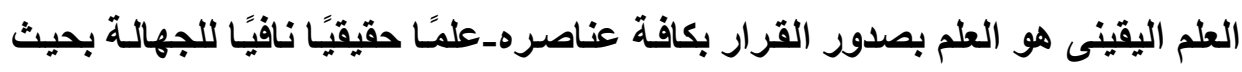

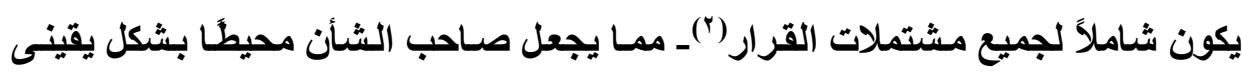

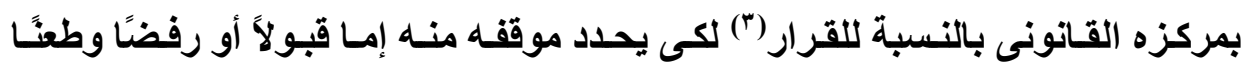

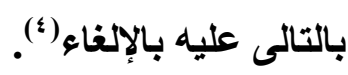

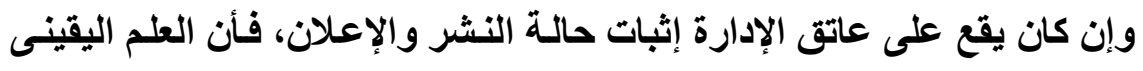

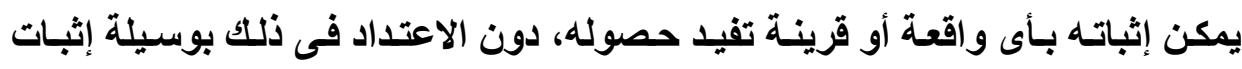

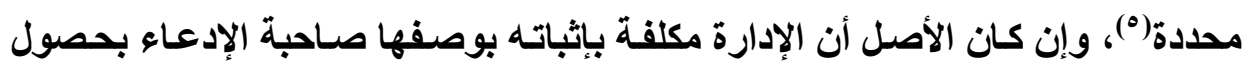

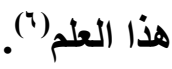

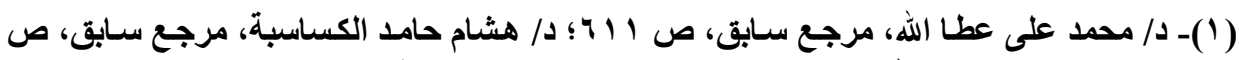

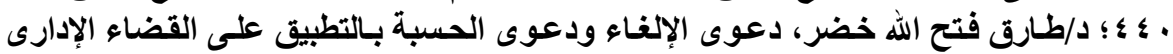

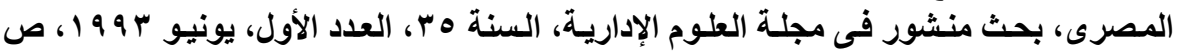
$.1 \cdot r$

(2)- Patrick Fraissex, Vers la fin de la théorie de la connaissanceacquise, R.D.P. 3, mai-juin 1999, p. 759.

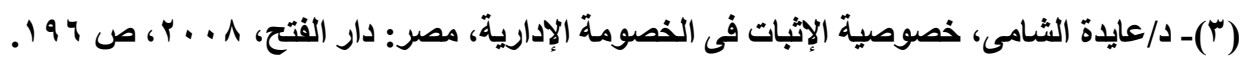

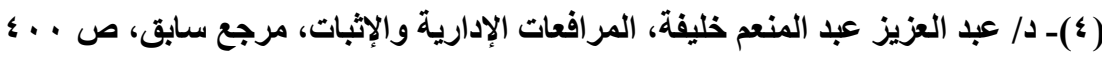

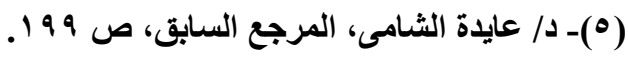

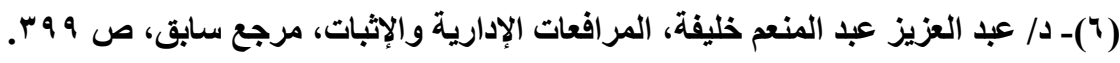


وهو مـا أكلته المحكة الإداريـة العليـا بحكمها الذى ذهبت فيه إلى أن "نظريـة العلم اليقينى هـ نظريـة من خلث القضاء الإدارى، ومؤداهـا إذا علـم صـاحب الشـأن بمضمون القرار الإدارى ومحتوياته علمًا حقيقيًا يقتيًا يقوم مقام النشر والإعلان، ويبدأ من تاريخ ثبوت ذلك العلم سريان ميعاد الطعن بالإلغاء، ويجب أن يكون ذلك العلم يقتيًا لا ظنيًا ولا افتراضيًا، وأن يكون شاملاً لجميع محتويات القرار" (') وفـى حكـم آخـر أكـدت المحكمـة الإداريـة العليـا بـأن العــم اليقينـى بـالقرار الإدارى"يثبت هذا العلم من أية واقعة أو قرينة تفيد حصوله دون التقيد فى ذلك بوسيلة إثبات معينة وللقضاء الإدارى فى أعمال رقابته القانونية التحقق من قيام أو عدم قيام

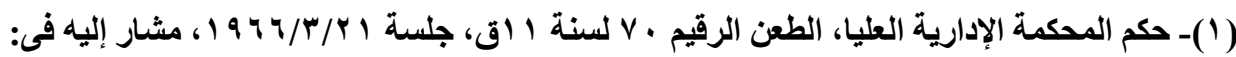

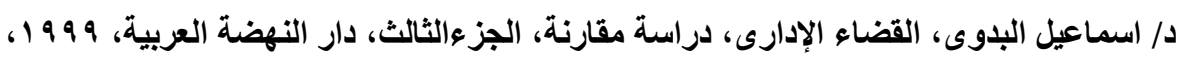

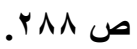

راجع أيضًا حكم المحكمة الإدارية العليا الذى ذهبت فيه إلى أن "ومن حيث أن قضاء هذه الأن المحكمة

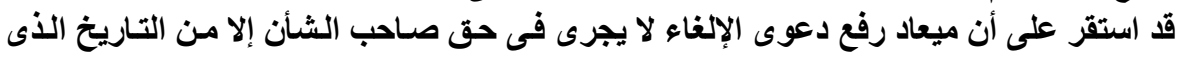

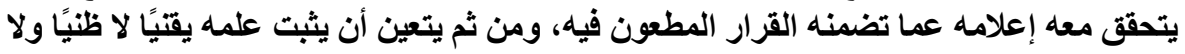

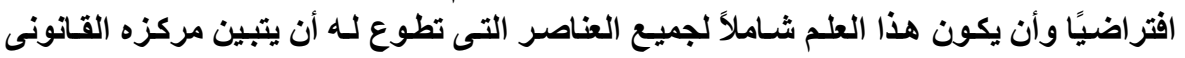

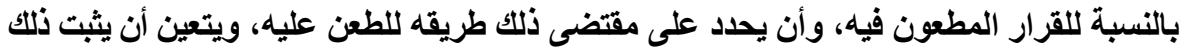

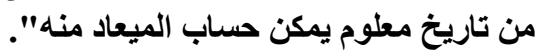

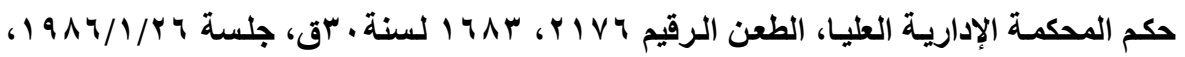

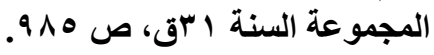

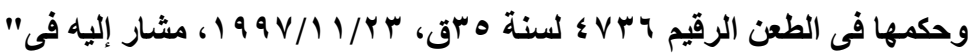

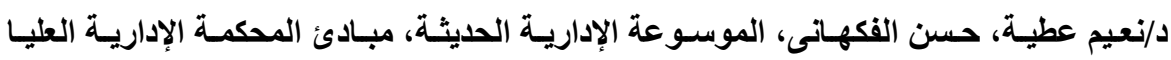

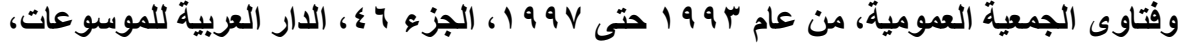


هذه القرينة أو تلك الواقعة، وتقرير الأثر الذى يمكن ترتيبه عليها من حيث غايـة العلم أو قصوره، وذلك حسبما تستبينه المحكمة من الأوراق وظروف الحال"('). وفى حكم آخر أبرزت فيه المحكمة أن التعلل بـالعلم اليقينى ينكشف من ظروف الحال ولا يمكن التحايل من خلاله للطعن على القرارات الإدارية، ما قضت به أن "ميعاد رفع الدعوى بإلغاء القرارات الإدارية يبدأ من تاريخ نشر القرار المطعون فيه أو إعلانه أو العلم اليقينى بهـلا يجوز اتخاذ عدم العلم اليقينى ذريعة للطعن على القرارات الإدارية

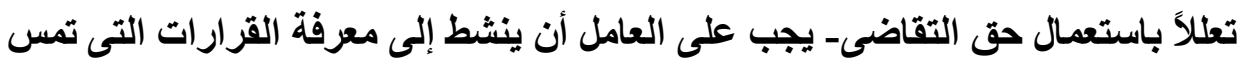
مركزه الوظيفى، وأن يبادر إلى مواجهتها فى الوقت المناسب فى الميعاد الذى حدده

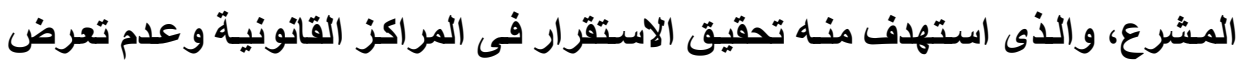
الأوضاع الإدارية للاضطراب_الادعاء بعدم العلم مع استطالة الوقت بين صدور القرار

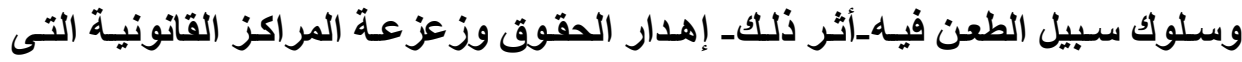
استقرت على مر السنين وهو ما تأباه قواعد العدالة_عليه فأن للمحكمة أن تتكشف من ظروف الحال أن صاحب الثـأن كان فى مركز يتعين معه علمـه اليقينى بـالقرار المؤثر

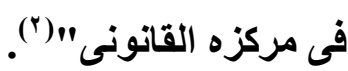
ومن الأحكام الهامة فى هذا السياق مـا أكدته المحكمة الإداريـة العليـا من عدم تـوافر العلم اليقينى "بـدور قرار فصل أحد العـاملين مـن عملهـه بمنعـه مـن دخول الثركة، حيث لا تنبئ تلك الواقعة بذاتها عن صدور قرار فصل فقد يكون المنع للوقف متفي

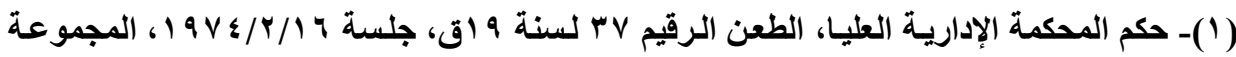

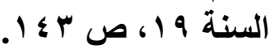

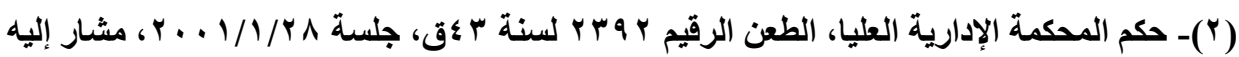

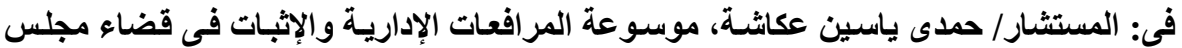

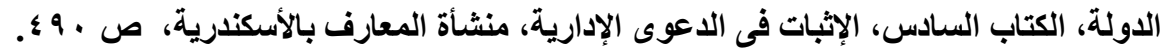


عن العمل مثلاً، وبالتالى لا يثبت فى حقه العلم اليقينى بقرار الفصل من الخدمة بصورة يمكنه معها تحديا موقفه منه" (') ومن ثم فِان الواقعة التى قد تثير إلى احتمالين لا يقبل معها القول بـأن صـاحب الشأن يعلم علمًا يقتيًا بأحدهما، لأن هذا الافتراض يستند إلى شك وتخمين غير جائز فى مجال إقامة الاليل على العلم اليقينى بالقرار الأى يجب أن يكون قاطعًا فى دلالته على

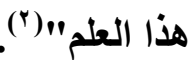
ولـم يتوسـع القضاء الإدارى الفرنسـى مـن قاعدة العلـم اليقينـى بـالقرار، فهو يطبقها فى حالات محدودة على سبيل الاستثناء(")، يستفاد فيها العلم القينى الشامل بمضمون القرار، من ذلك علم أعضاء المجالس واللجان بمـا يصدر عنها من قرارات، وبالتالى يسرى ميعاد الطعن فيها فى حقهم من تاريخ صدورها(")؛ ومنهـا علم صساحب الشأن بالقرار الوارد فى حيثيات حكم قضائى أعلن إليه دون إعلانه بالقرار ذاته(ْ). فالقضاء الإدارى الفرنسى لا يعثد كأصل عام إلا بوسيلتى النشر والإعلان، ومرد

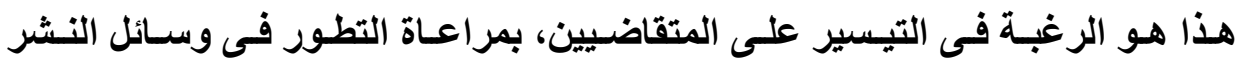
والإعلان وانتشارها، مما لا محل بعده إلى إضافة وسيلة أخرى للعلم بالقرار الإدارى لم

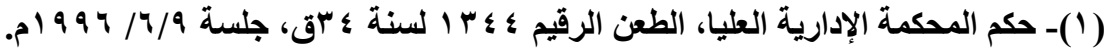

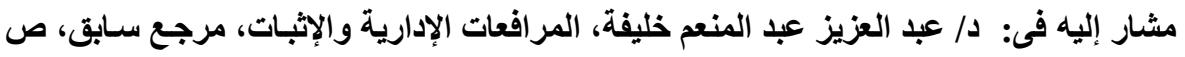
$\varepsilon \cdot r_{-} \varepsilon \cdot 1$ (Yr)- د/ عبد العزيز عبد المنعم خليفة، دعوى إلغاء القرار الإدارى فى قضاء مجلس الدولة، منشأة

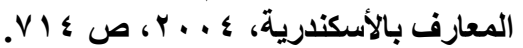

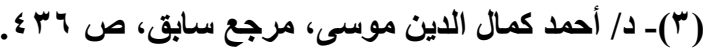
(4)- C.E. 4/8/1905, Martin.Rec., p.749.

(5)- C.E. 23/5/1952, Rogé, Rec., p.273. 
ينص عليها القانون(')، بالإضـافة إلى أنها يتنـافى مع سياسـة المجلس فى الرغبة فى التخفيف على الأفراد وتلمس الأعذار لهم فى تـأخير بـداء سـريان اللـة على قدر

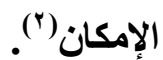

وذهب من أهل الفقه(") إلى أنه تتحصل التطبيقات القضائية بشأن تحقق قرينة

$$
\text { العلم اليقينى بالقرار الإدارى فى حالتين: }
$$

ا ـ حالة اعتراف صاحب الثأن بالعلم بالقرار الإدارى علمًا كافيًا، باعتبار أن

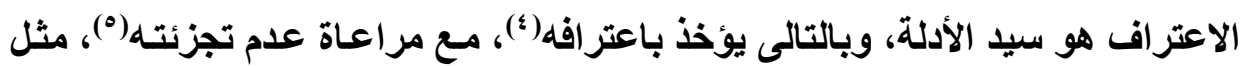

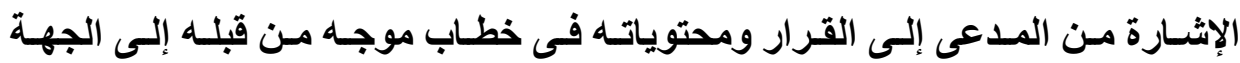

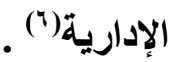
r- ـالـة تنفيذ الإدارة للقرار الإدارى على وجـه يفيد العلم الكامل بمحتويـات

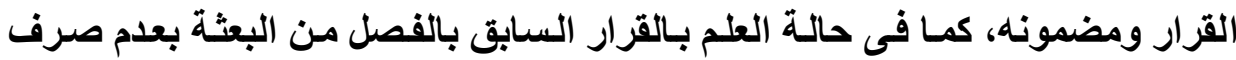

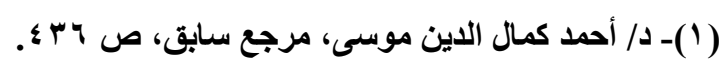

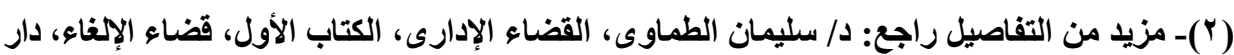

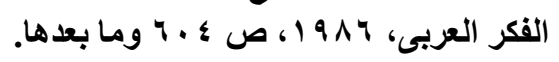

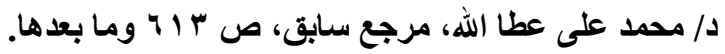

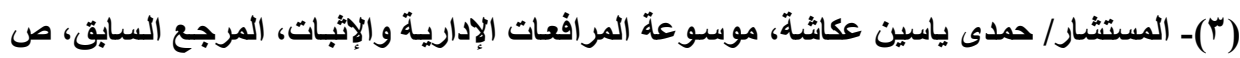

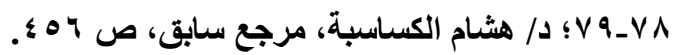

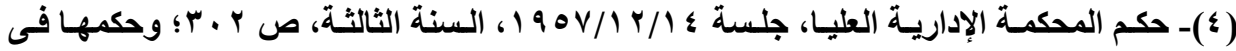

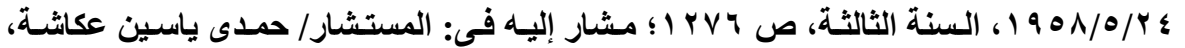

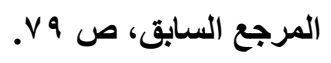

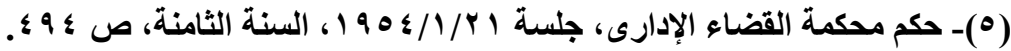

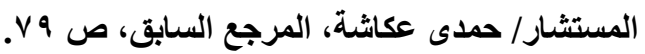

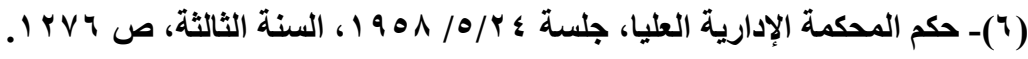


باقى المرتبات المستحقة أثناء البعثة باعتباره نتيجة حتمية للقرار الصادر بالفصل(')؛ وقضت محكمة القضاء الإدارى بأنه "يستفاد من تجنيا المدعى علمه على وجه اليقين بالقرار المطعون فيه الصادر بتجنيده، ومثل هذا العلم يقوم مقام النشر أو الإعلان طبقَّا لما استقر عليه قضاء هذه المحكمة، فإذا لم ترفع الدعوى فى الميعاد كان الدفع بعدم قبولها قائمًا على أساس من القانون"(").

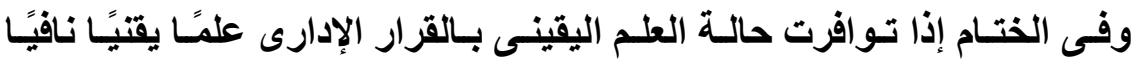
للجهائة بشكل يمكن المدعى من العلم بمحتوياته وعناصره، فإنه إذا لم يطعن فى القرار الإدارى خلال سنتين يومًا من تاريخ تحقى هذا العلم اليقينى تحصن القرار الإدارى ضد الطعن بالإلغاء (") - (ب)

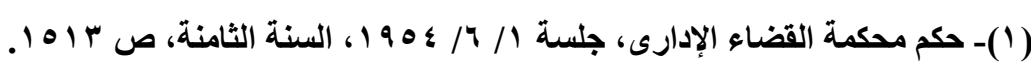
مشار إليه فى المستشار/حمدى عكاشة، موسوعة المرافعات الإدارية والإثبات، المرجع السابق، ص 9 ט

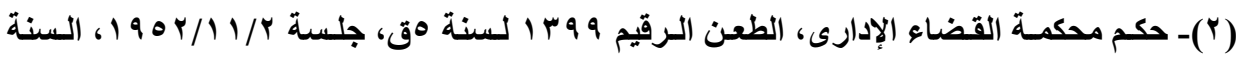

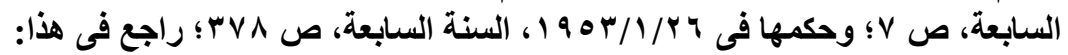

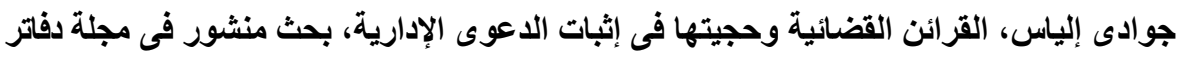

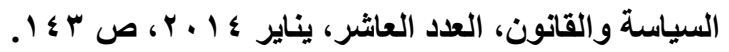

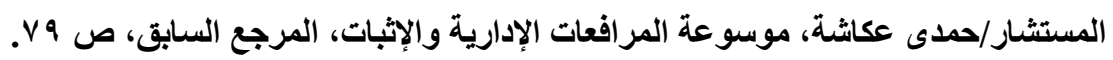

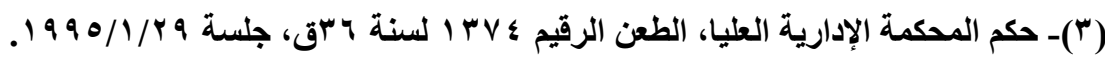

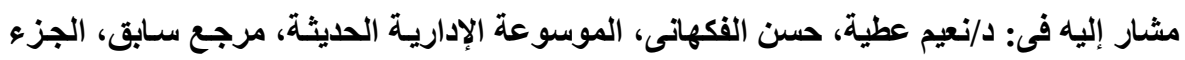

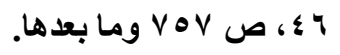




\section{الخاتهة}

إن كان الأصل فى عبء الإثبات أنه يقع على عاتق المدعى، إلا أنـه تقديرًا من القضاء إذا ألقى القاضى عبء الإثبات فى اللدعوى الإدارية على كاهل المدعى عليه طالما توافرت بعض الدلالات والإمـارات التى تدفع القاضى إلى اعتبار إن المدعى قد الداء يكون فى جانبه الصواب لتوافر هذه الدلالات، ويصبح المدعى عليه فى الدعوى إثبات

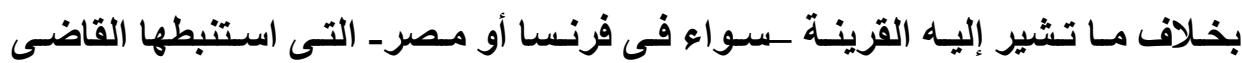

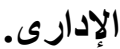

وقد خلصت الدراسـة إلى بعض النتائج التى يلزم أن نتعرض لها لكى تكتمل

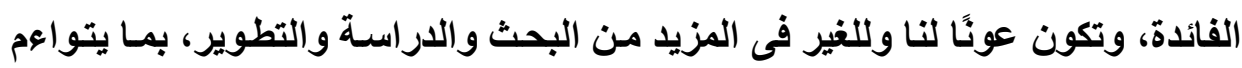
ويتو افق مع كل تطور فى المجتمع.

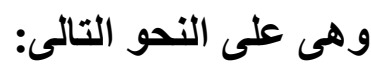

1 ـ تمثل القرائن وسيلة من وسـائل الإثبات المتقدمة التى يلجأ إليها القاضس، ويشكل خاص القاضى الإدارى، لما لله من دور إيجابى فى الدعوى الإدارية، حتى يتمكن الإنه

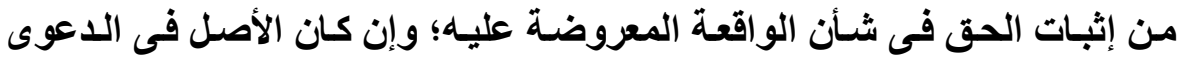

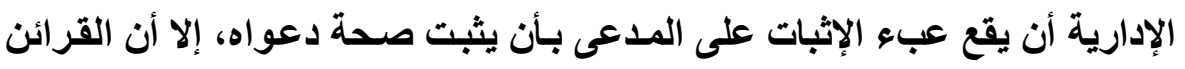

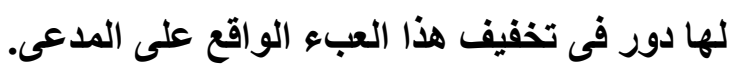
r - يمكن حصر القرائن فى نوعين، وهى القرائن القانونية التى يستنبطها المشرع وينص عليها وأن كانت تجد أصلها فى القرائن القضائية، وقرائن قضائية إذا كان النيان 
استنباطها من قبل القاضس، ووقائع، وملابسات الدعوى، ومناقشة الشهود أو

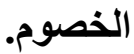

rــ تؤدى القرائن القضائية التى يستخلصها القاضى الإدارى إلى تيسير عبء الإثبات

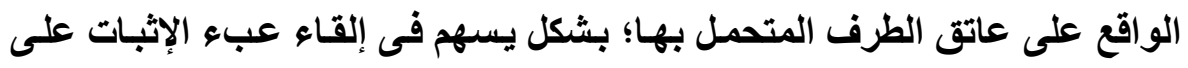
الطرف الآخر الذى تعمل القرينة ضده.

عـ تعتبر القرائن القضائية فى القانون الإدارى فى مقدمة أدلة الإثبات الى يعتمد عليها

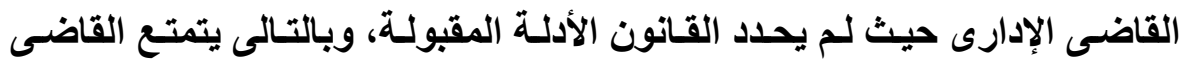
بسلطة تقديرية واسعة فى وزن، وتقدير ما يقدم إليه من أدلة وعناصر. هـ ما يثبت بالقرائن القضائية له حجية متعدية أى أنه يعتبر ثابتًا بالنسبة إلى الكافة لأن أساسه وقائع مادية ثابتة يتحقى منها القاضى شخصيًا. צ- من الأمور التى استقر عليها فى النظام القضائى سواء المصرى أو الفرنسى، قرينة

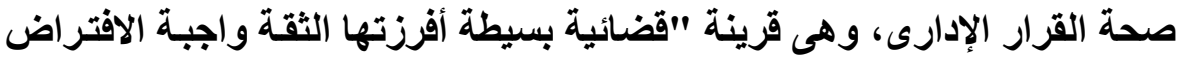

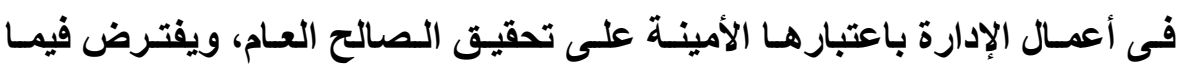
تصدره من قرارات أنها سليمة من الناحية القانونية، طالما لم يثبت خلاف ذلك. V- إن قضاء مجلسى الدولة الفرنسى والمصرى، قد استقرا على إمكانية استخلاص عيب اساءة استعمال السلطة من الظروف والملابسات التى احاطت إصدار القرار والكيفية التى نفذ بها، فإذا أصدرت الإدارة قرارها بعيدًا عن باعث تحقيق المصلحة العامة أو الهذف المخصص لها، تحت تأثير ظروف معينة أو تبين عدم الملاعمدة

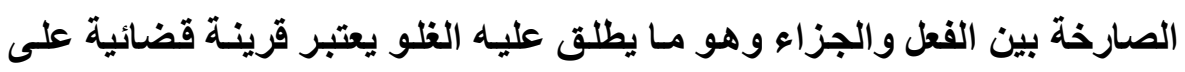
عيب اساءة استعمال السلطة الإدارية، يدفع لإلغاء القرار الإدارى فى حالة ثبوتهـ.

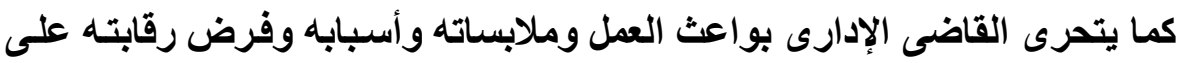


كل ذلك، للوقوف على الهدف الحقيقى الأى تنشده الجهة الإدارية فى قرارهـا، ومـا إذا كانت حقًا قد رمت به وجه المصلحة العامـة أم تنكبت السبيل وانحرفت بـه عن

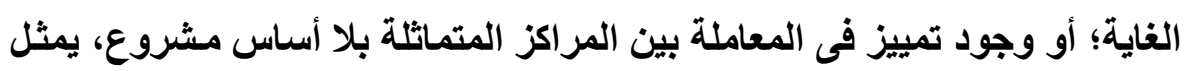
قرينة مؤداها توافر اساعة استعمال السلطة فى إصدار القرار.

^ـ اعتـدد القاضـى الإدارى بقرينـة العلـم اليقينـى، وهـو العـــم بـصدور القـرار بكافـة

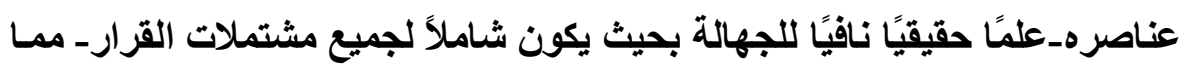
يجعل صاحب الشأن محيطا بشكل يقينى بمركزه القاتونى بالنسبة للقرار لكى يحدد

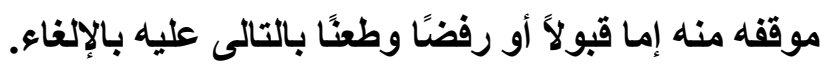
ونهيب فى خاتمة هذه الاراسة، بالقاضى الإدارى أن يعمل المزيد من الجهـ من

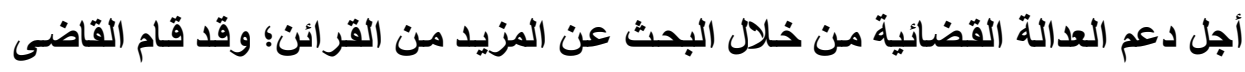
الإدارى بدور فعال فى هذا السياق من خـلال تبنيـه العديد من القرائن القضائية التى اصبح لها دور كبير فى الإثبات الإدارى، مما يسهم فى التخفيف من عبء الإثبات على هلى الطرف التى تعمل القرينة لصالحه.

$$
\text { وآخر دعوانا أن الحمد لله رب العالمين. }
$$




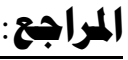

القرآن الكريم

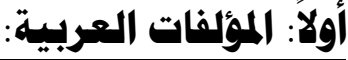

• أحمد بن بكر بن منظور، لسان العرب، الجزء الحادى عشر، الطبعة الثالثة،

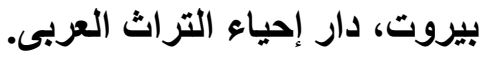

• د/ أحمد حشمت أبو ستيت، نظرية الالتزام فى القانون المدنى الجديد، الكتاب

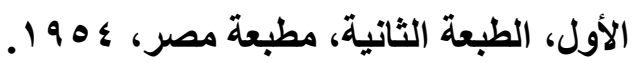

• د/ أحمد كمال الاين موسى، نظرية الإثبات فى القانون الإدارى، دار الشع،

$.19 \vee V$

• د/ أحمد كمال الدين موسى، نظريـة الإثبات فى القانون الإدارى، دار الشعب،

$.19 \vee V$

• د/ أحمــ مختـار عمـ، معجم اللغـة العربيـة المعاصر، الطبعة الأولس، عـالم

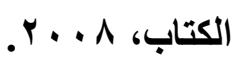

• د/ اســـاعيل البـدوى، القـضاء الإدارى، دراسـة مقارنــة، الجزءالثالـث، دار

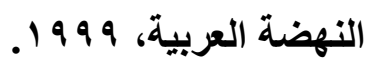

• • د/بجاش سرحان محمد المخلافى، القرائن ودورها فى الإثبات، دراسة مقارنة،

رسالة دكتوراه، كلية الحقوق، جامعة عين شمس، ؛ 99 1.

• ادو إلياس، القرائن القضائية وحجيتها فى إثبات الدعوى الإداريـة، بحث

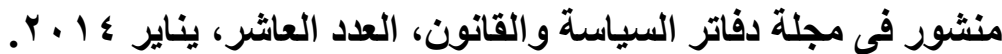

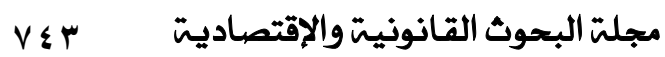


• حسين عثمان، القانون الإدارى، الطبعة الأولى، الدار الجامعية، 999 1 . • د/حمدى ياسين عكاشـة، موسـوعة القرار الإدارى، فى قضاء مجلس الدولة،

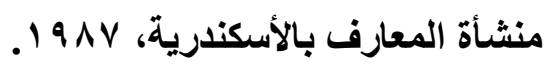
• د/حمـدى ياسـين عكاثـة، موسـوعة المرافعـات الإداريـة والإثبـات فـى قضاء مجلس الدولة، الكتاب السادس، الإثبات فى الدعوى الإدارية، منشأة المعارف بالأسكندرية. د/ رؤوف عبيد : مبادئ الإجراءات الجنائية فى القـانون المصرى، دار الجيل، $.19 \vee 9$

د/ سامى صادق الملا،/عتراف المتهم، الطبعة الثانية، ه 9 ه . • د/ سـر عبد الستار إمـام يوسف، دور القاضى فى الإثبات، دراسـة مقارنـة، رسالة دكتور اه، كلية الحقوق، جامعة عين شمس، 1 ... ب. • د/ سليمان الطماوى، القضاء الإدارى، الكتاب الأول، قضاء الإلغاء، دار القكر

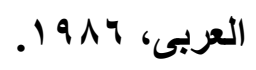

د/ سليمان مرقص، أصول الإثبات فى المواد المدنية، الطبعة الثانية، ، 99 19. • د/سليمان الطمـاوى، النظريـة العامـة للقرارات الإداريـة، دراسـة مقارنـة، دار

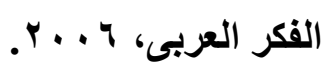

• د/سليمان الطمـاوى، نظريـة التعسف فـى استعمال السلطة، دراسـة مقارنـة،

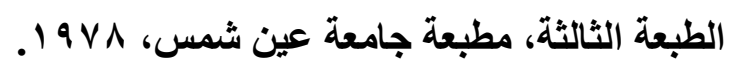
•صلاح حمدى، لبيب حليم، البيان فى شرح قانون الإثبات، الطبعة الأولى، دار الأدباء للطباعة والنشر، . 191 19. 
• د/طارق فتح الله خضر، دعوى الإلغاء ودعوى الحسبة بـالتطبيق على القضاء الإدارى المصرى، بحث منشور فى مجلة العلوم الإداريـة، السنة هـ هـ العدد

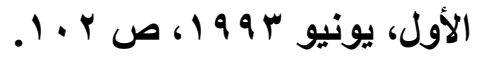
د/طعيمة الجرف، رقابة القضاء لأعمـال الإدارة العامـة، قضاء الإلغـاء، الطبعة

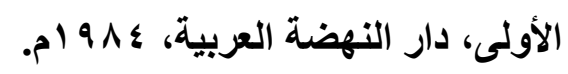
• د/ طعيمة الجرف، مبدأ المشروعية، وضوابط خضوع الدولة للقانون، با 9 ا ـ . • د/عايدة الثامى، خصوصية الإثبات فى الخصومة الإداريـة، مصر: دار الفتح، .. .1 • د/ عبد الرزاق السنهورى، الوسبط فى شرح القانون المدنى، الجزء الثانى، نظريـة الالتزام بوجـه عـام، تنقيح المستشار/ أحمـد مـدت المراغى، منشأة

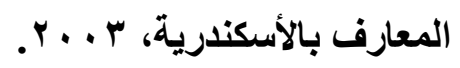
•عبد الفتاح سليمان، المبسط فى شرح نظام المرافعات الشرعية فى المملكة

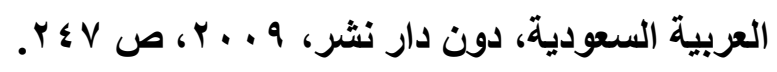
•المستشـار/عز الدين الدناصورى، والأستتاذ/ حامد عكاز، التعليق على قانون الإثبات، الطبعة التاسعة. •على بن محمد بن على الجرجانى، التعريفات للجرجانى، ضبطه محمد بن عبد الحكيم القاضى، ط1)، دار الكتاب، 199 19.

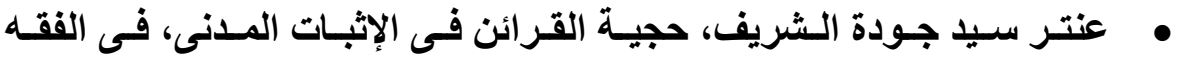
الإسلامى والقانون الوضعى، رسـالة دكتوراه، كلية الحقوق، جامعة القاهرة، ...$r$ 


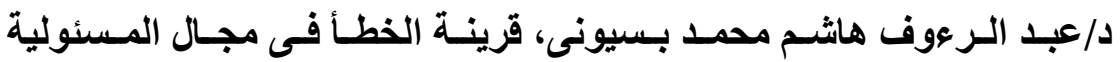

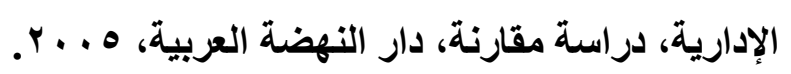

• د/عبد العزيز خليفة، الإنحراف بالسلطة كسبب لإلغاء القرار الإدارى، دراسة مقارنة، بين النظامين المصرى والفرنسى، دار الفكر الجامعى بالاسكندرية،

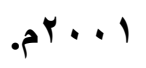

• • د دعبد العزيز عبد المنعم خليفة، المرافعات الإداريـة والإثبات أمسام القضاء

$$
\text { الإدارى، الطبعة الأولى، المركز القومى للإصدارات القانونية، } 1 \text {. . †. }
$$

• • د/عبد العزيز عبد المنعم خليفة، دعوى إلغاء القرار الإدارى فى قضاء مجلس

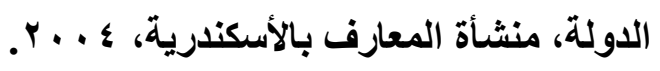

• د/عصام عبد الوهاب البرزنجى، السلطة التقايرية للإدارة والرقابة القضائية،

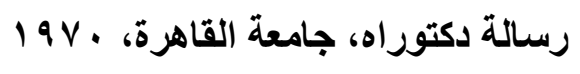

• د/عصمت عبدالله الثيخ، جدوى نظام وقف تنفيذ القرارات الإدارية فى تحقيق

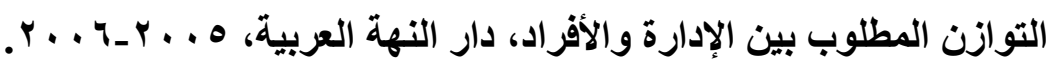

ه/عمر محمود حسن، العلم بالقرينـة وأثره على الأحكام القضائية، المجلة

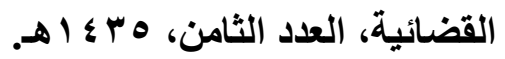

• د/فاروق عبد البر، دور مجلس الدولة المصرى فى حماية الحقوق والحريـات

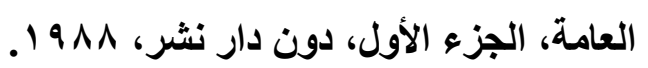

• د/فتح الله زيد، حجية القرائن فى القانون والثريعة، رسـالة دكتوراه، جامعة

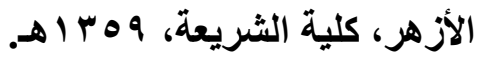


• د/فوزية عبد الستار، القضاء فى الإسلام، الطبعة الأولى، مركز الأهرام للنشر

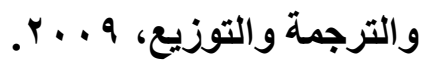

• مستشار/مجدى هرجه، الإثبات الجنائى والمدنى فى ضوء الققه والقضاء،

• محمد بن أبى بكر بـن عبد القـادر الرازى، مختـار الصحاح، مكتبة لبنـان،

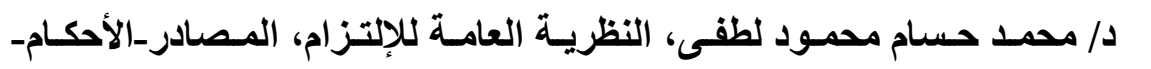

• د/ محمد عبد الواحد الجميلى، قضاء التعويض، مسئولية الدولة عن أعمالها

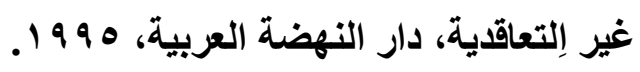

• المستشار/محمد عزمى البكرى، موسوعة الفقه و القضاء فى قانون الإثبات،

فى المواد المدنية والتجارية، المجلد الثالث، دار محمود للنشر والتوزيع.

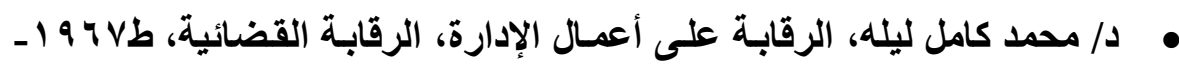

• د/ محمد مصطفى حسن، اتجاهات جليدة فى قضاء المحكمة الإدارية فى مجال

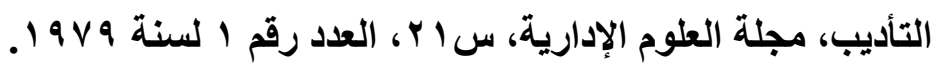
• د/ محمود حلمى، حق القضاء فى تعديل القرار الإدارى، مجلة العلوم الإدارية،

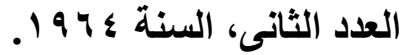
• د/ محمود حمدى عبـاس عطية، قرينـة صحة القرار الإدارى أمسام القضضاء

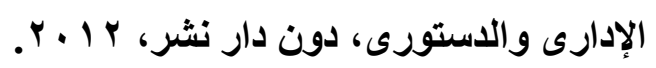


• د/ مصطفى أبو زيد فهمي، القضاء الإدارى ومجلس الدولة، دون دار نشر،

• د/ يسرى محمد العصار، قانون القضاء الإدارى، دار النهضة العربية، I1 ـ ؟ . • د/ يوسف المصاروة، الإثبات بالقرائن فى المواد المدنية والتجاريـة، دون دار نشر.

د/محمد الزحيلى، حجية القرائن المعاصرة فى الإثبات، دراسـة مقارنـة، بحث

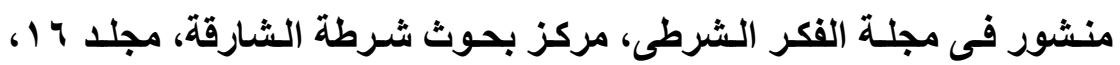

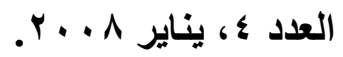

د/محمد طيب عمور، الإثبات بالقرائن القضائية بين الشريعة والقانون، مجلة الاكاديمية للاراسات الاجتماعية والإنسانية، كلية الحقوق، الجزائر، العدد 9 ، .

• د/محمـد على حسونة، قرينـة الخطأ، في مجـال المسئولية الإداريـة، دراسـة

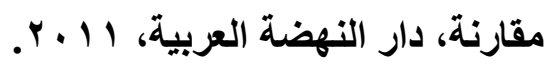

د/محمد على محمد عطا الله، الإثبات بـالقرائن فى القانون الإدارى والشريعة

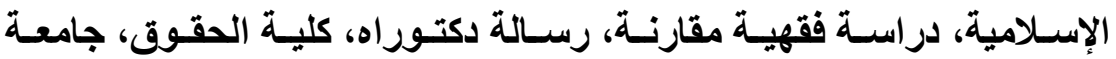
أسيوط، بدون تاريخ مناقشة.. • د/محمد على محمد عطا الله، الإثبات بـالقرائن فى القانون الإدارى والشريعة

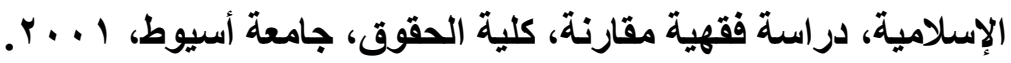

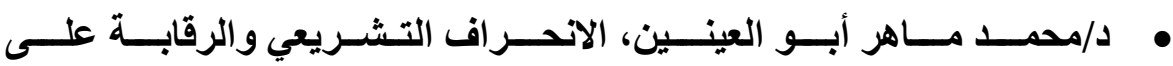

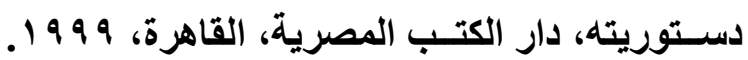


هامحمــ مـصطفى الزجيلـى، وسـائل الإثبـات فـى الـشريعة الإسـلامية، فـى

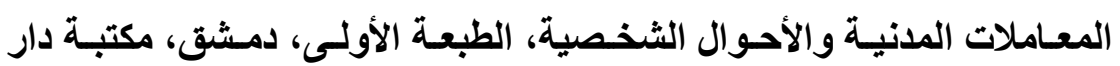

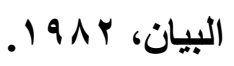

ه/محمود حلمى، القضاء الإدارى، قضاء الإلغـاء، القضاء الكامل، إجراءات

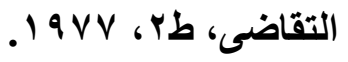

• د/محمود حمدى عباس عطية، قرينة النكول فى المنازعات الإدارية بين الواقع

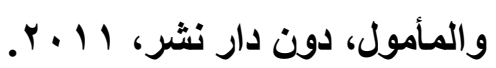

• د/مصطفى الزرقا، المدخل الفقهى العام، الجزء الثانى، الطبعة الأولى، دمشق،

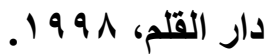

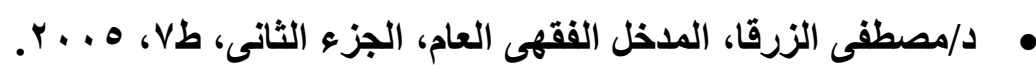
• د/مصطفى كمال وصفى، خصائص الإثبات أمام القضاء الإدارى، مقال منشور

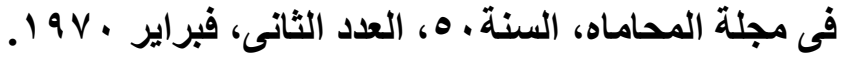
• د/هشام حامد سلمان الكساسبة، وسـائل الإثبات أمسام القضاء الإدارى، دراسـة

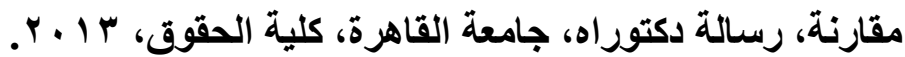
• • د/هشام عبد المنعم عكاثـة، دور القاضسى الإدارى فى الإثبات، دار النهضة

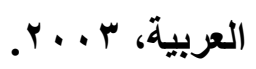

• د/هلالى عبد اللاه أحمد، النظريـة العامة للإثبات فى المواد الجنائية دراسـة

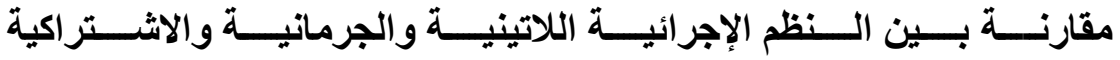

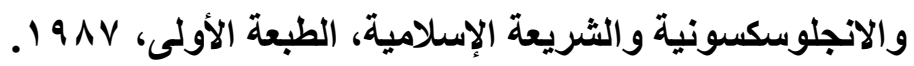


• د/ياسين محمد يحيى، القرائن القانونية وحجيتها فى الإثبات، دراسـة مقارنـة، دار التهضة العربية، . 99 19.

• د/ياسبين محمد يحيى، القرائن القانونية وحجيتها فى الإثبات، دراسـة مقارنـة،

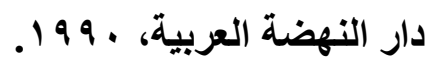
ثانيًا: الأحكام والمجموعات: • مجموعة الأعمال التحضيرية للقانون المدنى • نخبة من المستشارين، أحكام ومبادئ النقض فى مائة عام، فى قانون الإثبات، الجزء الثانى، مركز الأبحاث والدراسات القانونية، دون تاريخ نشر. • د/نعيم عطية، حسن الفكهانى، الموسوعة الإداريـة الحديثة، مبـادئ المحكمة

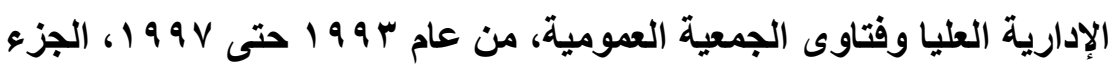
؟ ؛ ، الارار العربية للموسوعات. • مجموعات أحكام المحكمة الإدارية العليا، المكتب الفنى. ثالثا: الدوريات:

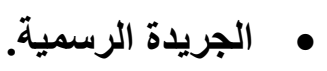

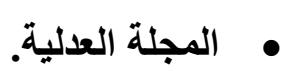
• مجلة الاكاديمية للار اسات الاجتماعية والإنسانية. • جلة العلوم الإدارية. • مجلة الفكر الشرطى. • المجلة القضائية. 


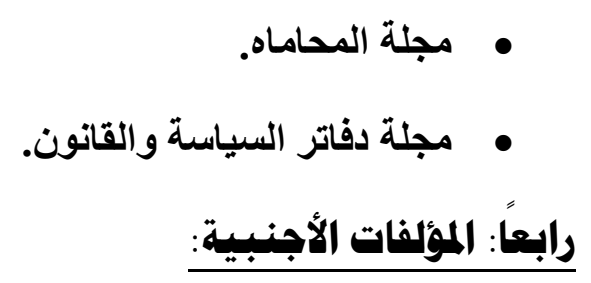

- Ch. Debbasch et Recci, contentieux administrative, D., 1985.

- Patrick Fraissex, Vers la fin de la théorie de la connaissanceacquise, R.D.P. 3, mai-juin 1999.

- PlaniolRipert et Baulanger :Traitéélémentaire de droit civil 3e édparise 1949 . Paris . T.II.

- J.-M. AUBY et R. DRAGO, Traité de contentieuxadministratif, t. II, 1984, 3 éd., LGDJ.

- Laferrière (E.), Traité de la jurisdiction administrative et des recourscontentieux, $2^{\mathrm{e} e ́ d ., ~ P a r i s, ~} 1896$.

- Vedel (G.), Droit administratif, Thémis. droit Presses Universitaires de France, 6 éd., Paris, 1976. 